\title{
Wild cereal grain consumption among Early Holocene foragers of the Balkans predates the arrival of agriculture
}

\section{Authors}

E. Cristiani ${ }^{1 *}$, A. Radini ${ }^{1,2}$, A. Zupancich ${ }^{1}$, A. Gismondi ${ }^{3}$, A. D’Agostino ${ }^{3}$, C. Ottoni ${ }^{1}$, M. Carra $^{1}$, S. Vukojičić ${ }^{4}$, M. Constantinescu ${ }^{5}$, D. Antonović ${ }^{6}$, T. Douglas Price ${ }^{7}$, D. Borici ${ }^{8,9,10^{*}}$

\section{Affiliations}

${ }^{1}$ DANTE - Diet and ANcient TEchnology Laboratory, Department of Oral and Maxillo-Facial Sciences, Sapienza University of Rome, Via Caserta 6, Rome 00161, Italy.

$12{ }^{2}$ Department of Archaeology, University of York, UK.

$13{ }^{3}$ Laboratory of General Botany, Department of Biology, University of Rome "Tor Vergata," 14 Via della Ricerca Scientifica 1, 00133 Rome, Italy.

${ }^{4}$ University of Belgrade, Faculty of Biology, Institute of Botany and Botanical Garden "Jevremovac", Takovska 43, 11000 Belgrade, Serbia.

5 Romanian Academy, Institute for Anthropological Research "Francisc I. Rainer," Bucarest, Romania.

${ }^{6}$ Institute of Archaeology, Knez Mihailova 35/IV, 11000 Belgrade, Serbia.

${ }^{7}$ Department of Anthropology, University of Wisconsin, 1180 Observatory Drive, WI 53706, Madison, USA.

8 The Italian Academy for Advanced Studies in America, Columbia University, 1161 Amsterdam Avenue, New York, NY 10024, USA.

${ }^{9}$ Department of Environmental Biology, Sapienza University of Rome, P.le A. Moro 5, Rome 00185, Italy.

${ }^{10}$ Department of Anthropology, New York University, 25 Waverly Place, 10003 New York, NY, USA.

\section{* Corresponding authors}

\section{Abstract}

Forager focus on wild cereal plants has been documented in the core zone of domestication in southwestern Asia, while evidence for forager use of wild grass grains remains sporadic elsewhere. In this paper, we present starch grain and phytolith analyses of dental calculus from 60 Mesolithic and Early Neolithic individuals from five sites in the Danube Gorges of the central Balkans. This zone was inhabited by likely complex Holocene foragers for several millennia before the appearance of the first farmers $\sim 6200 \mathrm{cal} \mathrm{BC}$. We also analyzed forager ground stone tools for evidence of plant processing. Our results based on the study of dental calculus show that certain species of Poaceae (species of the genus Aegilops) were used since the Early Mesolithic, while ground stone tools exhibit traces of a developed grass grain processing technology. The adoption of domesticated plants in this region after $\sim 6500 \mathrm{cal} B \mathrm{BC}$ might have been eased by the existing familiarity with wild cereals.

\section{Introduction}


Forager knowledge and consistent use of wild cereals are still debated and poorly documented outside of the assumed centers of domestication in Southwestern Asia (Kotsakis, 2003). For some time, it has been claimed that in the Balkans some forms of intense gathering or incipient human management of local plant and animal species might have occurred before the full-blown transition to the Neolithic (Clarke, 1978; Halstead, 1996; Kotsakis, 2003; Kotzamani and Livarda, 2014; Srejović, 1988; y'Edynak and Fleisch, 1983), partly due to the region's

In Southeastern Europe, specifically in its Mediterranean zone, where one would expect a greater spectrum of small seeded grasses, fruits, and nuts, forager consumption of wild cereals is well documented only at Franchthi Cave in Greece. Here, wild barley (Hordeum sp.) appears in the archaeobotanical record starting in the Late Upper Palaeolithic and throughout the Mesolithic, along with oat (Avena sp.), pulses (Lens sp. Mill.), bitter vetch (Vicia ervilia (L.) Willd.), almond (Prunus amygdalus Batscht), and terebinth (Pistacia cf. lentiscus L.) (Hansen, 1991; Van Andel et al., 1987). More recently, at Vlakno Cave in Croatia, starch granules of a wild species of barley (Hordeum spp.), along with those of oat (Avena spp.), were found in the dental calculus of a Mesolithic forager individual, dating to the late eight millennium cal BC burial (Cristiani et al., 2018).

Besides this type of evidence, data about the increase of cereal-type pollen in the Late Mesolithic come from palynological spectra from across Europe. Although the exclusive reliance on pollen evidence for inferring cultivation can be problematic, consistent evidence for interventions in the forest canopy, marked as disturbances in pollen spectra, might suggest anthropogenic activity. Due to low dispersal rates of cereal-type pollen grains as well as Cerealia-type pollens, their very presence in pollen spectra could be highly indicative of anthropic origin of disturbance phases (Edwards, 1989), and could be interpreted as forest clearances.

Recent methodological advances in our ability to analyse micro-residues in the form of microremains along with surface modifications and micro-residues on ground stone tools (henceforth GST) (Barton et al., 2018; Dubreuil and Nadel, 2015; Radini et al., 2017) have the potential to contribute to this old debate about Balkan and other prehistoric foragers' familiarity with plant species. Moreover, far from seeing foragers as passive recipients of novelties arriving from Neolithic groups at the time of agricultural transitions, there is now growing evidence of the active role of hunter-gatherers in shaping their landscape ecologies, including plant management, and manipulation of ecosystems through niche constructing (Lombardo et al., 2020; Rowley-Conwy and Layton, 2011; Smith, 2011).

We examine these pertinent issues in hunter-gatherer research by studying dental remains and GSTs found at Mesolithic and Neolithic sites in the Danube Gorges area of the north-central Balkans between present-day Serbia and Romania (Figs. 1,2,3). This is one of the best researched areas of Europe regarding the Mesolithic-Neolithic transition period with more than 
20 sites spanning the duration of the Epipalaeolithic through to the Mesolithic and Early Neolithic ( 13,000-5500 cal BC) (Bonsall, 2008; Borić, 2011, 2016; Radovanović, 1996; Srejović, 1972). Open-air sites began appearing in the archaeological record with the start of the Holocene warming on river terrace promontories in the vicinity of strong whirlpools, narrows, and rapids of the Danube, which facilitated intense fishing operations (Borić, 2011). The Early and Middle Mesolithic ( $9600-7300$ cal BC) deposits at many sites are damaged by later Mesolithic and Neolithic intrusions, but a number of burials have directly been AMS-dated to these early phases. From the Early Mesolithic onwards, these sites became places for a continuous interment of the dead (Borić, 2016; Borić et al., 2014; Radovanović, 1996), thus creating a substantial mortuary record, which is in the excess of 500 individuals. Osteological collections allowed for a host of bioarchaeological analyses to be applied on this material (Bonsall et al., 1997; Borić et al., 2004; Borić and Price, 2013; Mathieson et al., 2018). Fishing seems to have remained one of the main subsistence foci throughout the Holocene, with a possible intensification during the Late Mesolithic ( 7300-6200 cal BC), the period that saw an intense inhabitation of the area, with recognizable features in the archaeological record, such as stone-lined rectangular hearths and abundant primary burials placed as extended inhumations parallel to the Danube River. Between $\sim 6200$ and 5900 cal BC, there are clearest indications based on both material culture associations and isotope and genomic data (Borić and Price, 2013; Mathieson et al., 2018) that the local Mesolithic foragers came into contact with the first Neolithic groups appearing in this region, and who likely founded several new sites in this area, especially in the downstream part of the region. These documented encounters of two different cultural groups are most clearly observed at the site of Lepenski Vir (Borić, 2016; Borić et al., 2018). After $\sim 5900 \mathrm{cal} B C$, it seems that the forager cultural specificity was lost and that various sites remained to be used as typical Early Neolithic Starčevo culture villages up until $\sim 5500 \mathrm{cal}$ $\mathrm{BC}$, when most of the previously used locales were abandoned.

While sources of animal protein in the diet of Mesolithic-Neolithic inhabitants of the area are well understood by now, the significance of plant foods in this region has remained less well known. Non-flaked tools such as pestles, grinders, crushers, and anvils have recently been associated with fruit, seed, and nut processing in early prehistoric and ethnographic contexts (de Beaune, 2004; Dubreuil and Nadel, 2015; Hamon et al., 2021; Pardoe et al., 2019; Wright, 1994) . However, this category of artefacts is primarily documented from the Late Mesolithic onwards and only sporadically associated with earlier periods in the region of the Danube Gorges (Antonović et al., 2006; Borić et al., 2014; Srejović and Letica, 1978).

Such a lack of evidence about the role of plant foods in Mesolithic stems from very limited attempts to recover macro-botanical remains through intense sediment flotation, which has only been applied at two more recently excavated sites in this region-Schela Cladovei (Mason et al., 1996) and Vlasac (Borić et al., 2014; Mason et al., 1996). Despite a generally poor preservation of plant remains due to taphonomic issues, recent carpological analyses indicated a relatively wide spectrum of wild resources available to the local Mesolithic foragers. These included drupes, fruits, and berries (Marinova et al., 2013), among which cornelian cherry (Cornus mas L.), hazelnut (Corylus avellana L.), and elderberry (Sambucus nigra L.) were the most frequent taxa (Filipović et al., 2010; Marinova et al., 2013). Molecular record of C. avellana and S. nigra 
was also found preserved in the dental calculus of two Late Mesolithic individuals from Vlasac, which underwent metagenomic analysis (Ottoni et al., 2021). Moreover, in the study region of the Danube Gorges, at the site of Vlasac, presumed human palaeofeces contained pollen of Amaranthaceae and Cerealia (Cârciumaru, 1978). Evidence from the Mesolithic levels at the site of Icoana, located in the same region, has suggested local cereal cultivation (Cârciumaru, 1973). Pollen provides only indirect evidence for consumption and cultivation and, unfortunately, the 1960-70s excavations of the sites in the Danube Gorges did not involve any flotation of contextual units associated with burning in domestic contexts. While the extensive program of flotation at the site of Vlasac in the course of more recent work (2006-2009) has not led to the discovery of macro-botanical remains of wild or domesticated cereal grains, it should also be emphasized that the new excavations at this site have taken place in a marginal, upslope part of the site with little or no evidence of domestic features associated with burning that might have preserved macro-botanical remains (Borić et al., 2014). More recently, starch granules identified in dental calculus within a sample of 12 individuals provided evidence for the consumption of domesticated cereals at the site of Vlasac during the Late Mesolithic (Cristiani et al., 2016).

Hence, plant debris recovered in human dental calculus constitute the most reliable line of evidence to unveil the role of plants in the local forager diets. Our previous pilot study has provided the first evidence of domesticated cereal grains and plant food consumption in the Late Mesolithic from the analyses of dental calculus (Cristiani et al., 2016). Based on a more robust sample of human dental calculus, which now also involves numerous Early Mesolithic individuals not included in our previous study, and complementary functional evidence from the most conspicuous assemblage of Mesolithic GSTs from the Danube Gorges, the present study details forager use of certain species of the Triticeae tribe and other plant foods in the region already since $\sim 9500 \mathrm{cal} \mathrm{BC}$.

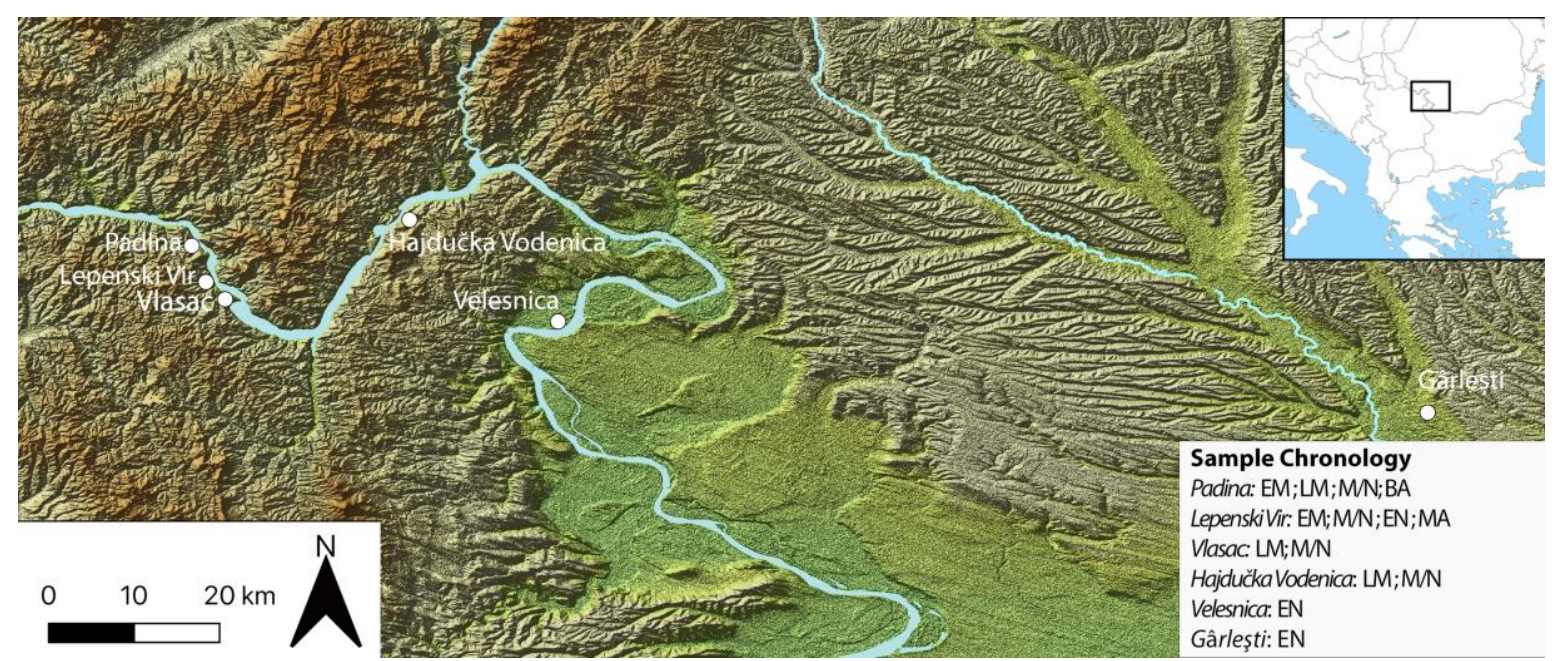

Figure 1. Sites in the central Balkans investigated in the article, which provided dental calculus and ground stone tools. $\mathrm{EM}=$ Early Mesolithic; $\mathrm{LM}=$ Late Mesolithic; $\mathrm{M} / \mathrm{N}=$ Mesolithic/Neolithic; $\mathrm{N}=$ Neolithic; BA = Bronze Age; MA = Medieval. 


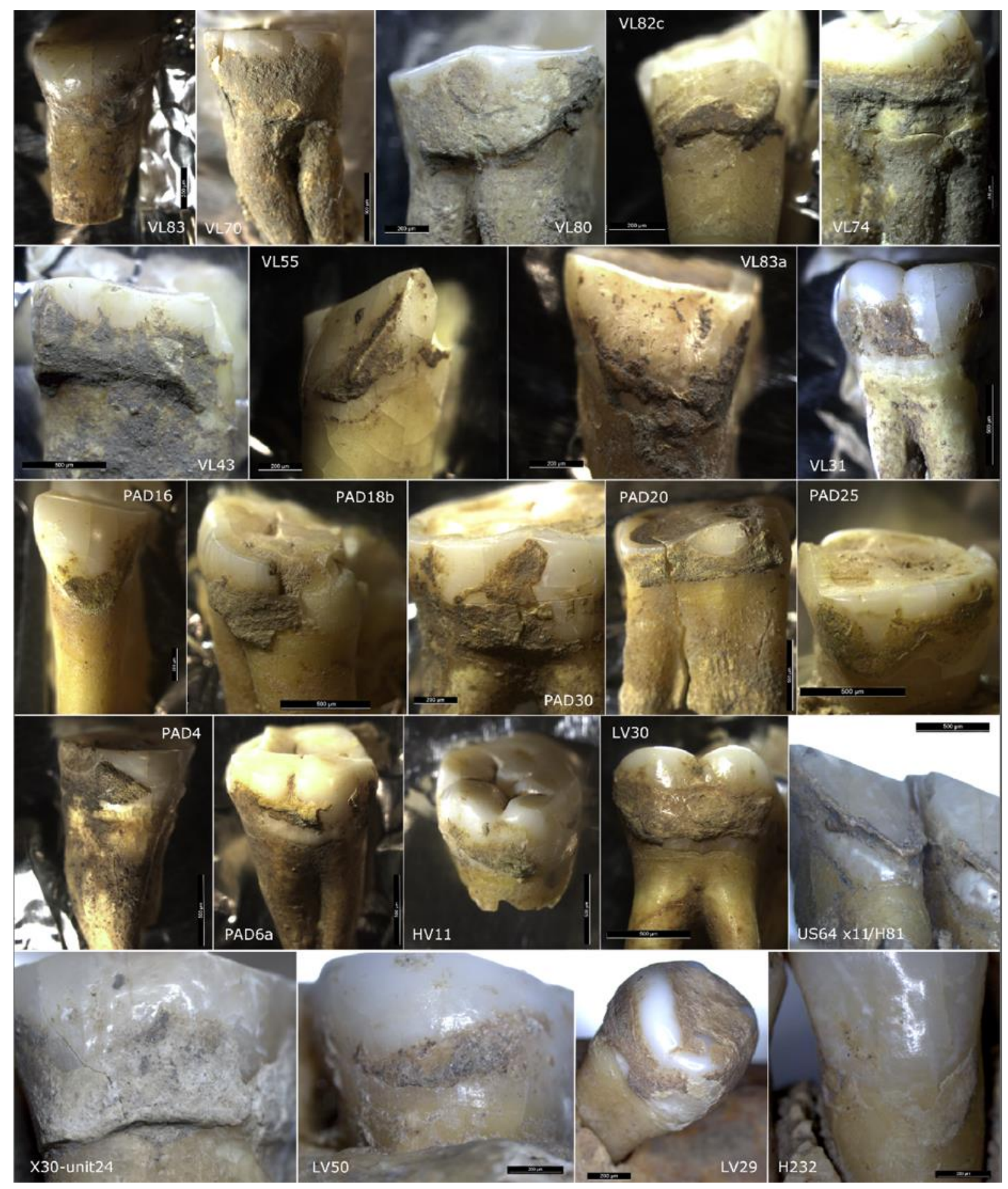

165 Figure 2. Studied teeth photographed under the microscope before dental calculus sampling. 

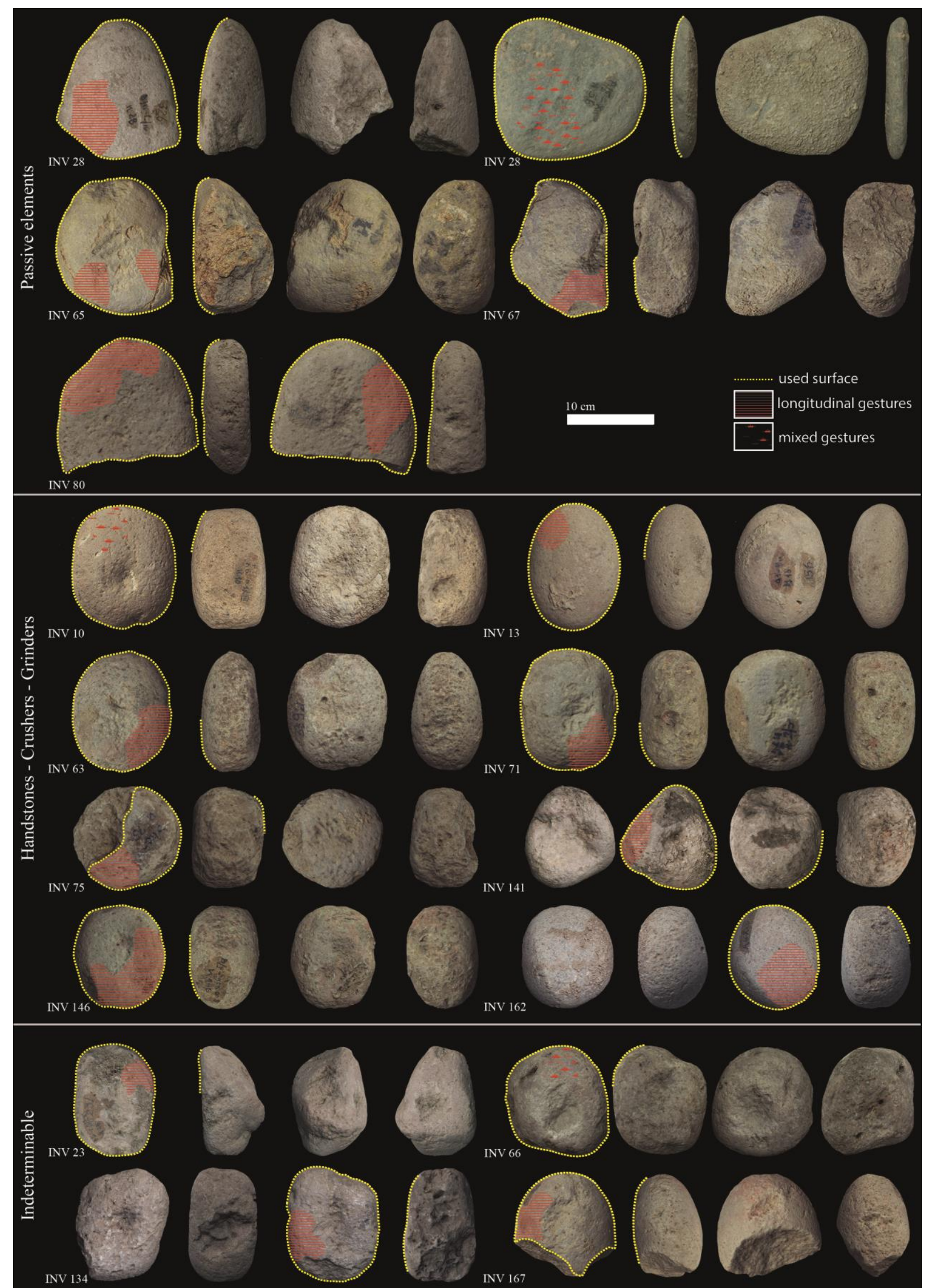

Figure 3. Late Mesolithic GSTs from the site of Vlasac featuring use-wear traces and residues 168 related to plant food processing. 
174 Starch granules were almost ubiquitous in the analyzed individuals and many of them were 175 found still in part associated with dental calculus remains. Six morphotypes have been retrieved 176 in this study (Tables 1,2). We have not attempted the identification of starch granules less than 5 $177 \mu \mathrm{m}$ to avoid misinterpretation of transitory and small storage starch granules (Haslam, 2004).

Table 1. Details of dental calculus sampled for the study $(\mathrm{n}=60)$ * no stable isotope values are currently available for this individual in order to correct the obtained radiocarbon date for the reservoir effect, and the calibrated range should probably be considered too old for its actual age, likely being 200-500 years younger. All calibrated ranges have end points rounded outwards to 5 years. The dates were individually calibrated using OxCal 4.4 and IntCal 20 184 (Reimer et al., 2020). 


\begin{tabular}{|c|c|c|c|c|c|c|c|c|c|}
\hline \multirow[t]{2}{*}{ Site } & \multirow{2}{*}{$\begin{array}{c}\text { Burial } \\
\text { no. }\end{array}$} & \multirow{2}{*}{$\begin{array}{l}\text { Period } \\
\text { attribution }\end{array}$} & \multicolumn{4}{|c|}{ AMS dates } & \multicolumn{3}{|c|}{ Calculus location } \\
\hline & & & $\begin{array}{l}\text { Lab Code and } \\
\text { Source }\end{array}$ & $\begin{array}{c}{ }^{14} \text { C age } \\
(B P)\end{array}$ & $\begin{array}{c}\text { Reservoir effect } \\
\text { corrected age } \\
(B P)\end{array}$ & $\begin{array}{c}95.4 \% \\
\text { confidence, } \\
\text { cal BC }\end{array}$ & Tooth & Surface & $\begin{array}{c}\text { Weight } \\
(m g)\end{array}$ \\
\hline Padina & PAD20 & Early Meso & & & & & 17 & buccal & 9.6 \\
\hline Padina & PAD25 & Early Meso & & & & & 38 & buccal & 9.59 \\
\hline Padina & PAD15 & Early Meso & $\begin{array}{c}\text { OxA-17145 } \\
\text { (Borić, 2011) }\end{array}$ & $9310 \pm 44$ & $8870 \pm 63$ & $8240-7770$ & 38 & lingual & 9.58 \\
\hline Padina & $\begin{array}{c}\text { PAD16 } \\
\text { a }\end{array}$ & Early Meso & $\begin{array}{l}\text { PSU-2407 } \\
\text { (Mathieson et } \\
\text { al., 2018) }\end{array}$ & $9340 \pm 35$ & $8907 \pm 66$ & $8275-7815$ & 34 & buccal & 9.62 \\
\hline Padina & $\begin{array}{c}\text { PAD18 } \\
\text { b }\end{array}$ & Early Meso & $\begin{array}{c}\text { PSU-2376 } \\
\text { (Mathieson et } \\
\text { al., 2018) }\end{array}$ & $9715 \pm 40$ & $9424 \pm 55$ & $9115-8550$ & 48 & lingual & 9.67 \\
\hline Padina & PAD9 & Early Meso & $\begin{array}{c}\text { AA-57771 } \\
\text { (Borić, 2011) }\end{array}$ & $9920 \pm 100$ & $9480 \pm 110$ & $9225-8495$ & 42,46 & lingual & 9.59 \\
\hline Padina & PAD11 & Early Meso & $\begin{array}{c}\text { OxA-16938 } \\
\text { (Borić, 2011) }\end{array}$ & $9665 \pm 54$ & $9225 \pm 70$ & $8620-8290$ & 27 & lingual & 9.57 \\
\hline Padina & PAD12 & Early Meso & $\begin{array}{c}\text { BM-1146 } \\
\text { (Borić, 2011) }\end{array}$ & $9331 \pm 58$ & - & $8750-8350$ & 27 & lingual & 9.76 \\
\hline Padina & PAD17 & Early Meso & $\begin{array}{l}\text { PSU-2375 } \\
\text { (Mathieson et } \\
\text { al., 2018) }\end{array}$ & $9505 \pm 35$ & $9105 \pm 62$ & $8540-8230$ & 25 & buccal & 9.64 \\
\hline $\begin{array}{l}\text { Lepenski } \\
\text { Vir }\end{array}$ & LV50 & Early Meso & $\begin{array}{l}\text { BA-10651 } \\
\text { (Borić et al., } \\
2018 \text { ) } \\
\end{array}$ & $9455 \pm 38$ & $9082 \pm 62$ & $8540-8020$ & 35 & buccal & 9.99 \\
\hline $\begin{array}{c}\text { Lepenski } \\
\text { Vir }\end{array}$ & LV20 & Early Meso & $\begin{array}{r}\text { OxA-39629 } \\
\text { (this paper) }\end{array}$ & $10,268 \pm 38$ & $9928 \pm 58$ & $9740-9270$ & 48 & lingual & 9.73 \\
\hline Padina & PAD26 & Early Meso & & & & & 14 & buccal & 9.58 \\
\hline Padina & PAD6 & Early Meso & & & & & 47 & lingual & 9.65 \\
\hline Padina & PAD2 & Late Meso & $\begin{array}{c}\text { BM-1143 } \\
\text { (Borić, 2011) }\end{array}$ & $7738 \pm 51$ & - & $6650-6465$ & 36 & lingual & 9.68 \\
\hline $\begin{array}{l}\text { Hajdučka } \\
\text { Vodenica }\end{array}$ & $\begin{array}{c}\mathrm{HV} 25 / 2 \\
6\end{array}$ & Late Meso & & & & & 44 & buccal & 9.60 \\
\hline $\begin{array}{l}\text { Hajdučka } \\
\text { Vodenica }\end{array}$ & HV29 & Late Meso & $\begin{array}{c}\text { AA-577744 } \\
\text { (Borić, 2011) }\end{array}$ & $8151 \pm 60$ & $7711 \pm 75$ & $6690-6425$ & 48 & lingual & 10.72 \\
\hline $\begin{array}{l}\text { Hajdučka } \\
\text { Vodenica }\end{array}$ & HV8 & Late Meso & $\begin{array}{c}\text { OxA-13613 } \\
\text { (Borić, 2011) }\end{array}$ & $8456 \pm 37$ & $8016 \pm 58$ & $7075-6695$ & 48 & buccal & 9.61 \\
\hline $\begin{array}{l}\text { Hajdučka } \\
\text { Vodenica }\end{array}$ & HV11 & Late Meso & & & & & 48 & buccal & 9.71 \\
\hline $\begin{array}{l}\text { Hajdučka } \\
\text { Vodenica }\end{array}$ & $\begin{array}{c}\mathrm{HV} \\
\text { profil A }\end{array}$ & Late Meso & & & & & 27 & buccal & 9.70 \\
\hline $\begin{array}{l}\text { Hajdučka } \\
\text { Vodenica }\end{array}$ & HV30 & Late Meso & & & & & 27 & buccal & 9.56 \\
\hline Vlasac & VL82c & Late Meso & $\begin{array}{l}\text { BRAMS-2588 } \\
\text { (Jovanović et } \\
\text { al., 2021) }\end{array}$ & $8035 \pm 28$ & $7595 \pm 53$ & $6590-6270$ & 42 & buccal & 9.68 \\
\hline Vlasac & VL2 & Late Meso & & & & & 14 & buccal & 9.54 \\
\hline Vlasac & VL80a & Late Meso & & & & & 26 & lingual & 9.84 \\
\hline Vlasac & VL55 & Late Meso & $\begin{array}{l}\text { BRAMS-2583 } \\
\text { (Jovanović et } \\
\text { al., 2021) }\end{array}$ & $8377 \pm 29$ & $7837 \pm 63$ & $7035-6500$ & 33 & lingual & 9.64 \\
\hline Vlasac & VL74 & Late Meso & $\begin{array}{l}\text { BRAMS-2587 } \\
\text { (Jovanović et } \\
\text { al., 2021) }\end{array}$ & $8149 \pm 28$ & * & 7315-7055* & 28 & lingual & 9.70 \\
\hline Vlasac & VL83 & Late Meso & $\begin{array}{c}\text { OxA-5826 } \\
(\text { Borić, 2011) }\end{array}$ & $8200 \pm 90$ & $7760 \pm 100$ & $7030-6420$ & 24 & lingual & 9.62 \\
\hline Vlasac & VL43 & Late Meso & & & & & 27 & lingual & \\
\hline Vlasac & VL31 & Late Meso & $\begin{array}{c}\text { AA-57777 } \\
\text { (Borić, 2011) }\end{array}$ & $8196 \pm 69$ & $7756 \pm 82$ & 6900-6430 & 26 & buccal & 9.58 \\
\hline Vlasac & VL45 & Late Meso & $\begin{array}{l}\text { AA-57778 } \\
\text { (Borić et al., } \\
\text { 2008) }\end{array}$ & $8117 \pm 62$ & $7677 \pm 77$ & $6655-6400$ & 38 & buccal & 9.50 \\
\hline Vlasac & VL70 & Late Meso & & & & & 17 & buccal & 10.42 \\
\hline Vlasac & VL79 & Late Meso & $\begin{array}{c}\text { BRAMS-2448 } \\
\text { (Jovanović et } \\
\text { al., 2021) } \\
\end{array}$ & $8005 \pm 29$ & $7565 \pm 54$ & $6565-6250$ & 16 & buccal & 9.60 \\
\hline Vlasac & U44 & Late Meso & & & & & 27 & buccal & 9.96 \\
\hline Vlasac & $\mathrm{H} 232$ & Late Meso & $\begin{array}{c}\text { OxA-20702 } \\
(\text { Borić, 2011) }\end{array}$ & $7725 \pm 40$ & & $6640-6470$ & 28 & lingual & 9.92 \\
\hline Vlasac & H317 & Late Meso & $\begin{array}{l}\text { PSU-2381 } \\
\text { (Mathieson et } \\
\text { al., 2018) }\end{array}$ & $8110 \pm 35$ & $7625 \pm 71$ & $6645-6270$ & 26,36 & lingual & 9.73 \\
\hline Vlasac & U115 & Late Meso & & & & & 28 & buccal & 9.95 \\
\hline Vlasac & U326 & Late Meso & $\begin{array}{l}\text { PSU-2382 } \\
\text { (Mathieson et } \\
\text { al., 2018) }\end{array}$ & $8045 \pm 30$ & $7728 \pm 51$ & $6645-6465$ & 17 & buccal & 9.94 \\
\hline Vlasac & U326 & Late Meso & $\begin{array}{l}\text { PSU-2382 } \\
\text { (Mathieson et } \\
\text { al., 2018) }\end{array}$ & $8045 \pm 30$ & $7728 \pm 51$ & $6650-6460$ & 1,2 & buccal & 9.1 \\
\hline Vlasac & $\begin{array}{c}\mathrm{U} 64 \\
\mathrm{x} .11 / \mathrm{H} 8 \\
1\end{array}$ & Late Meso & $\begin{array}{c}\text { OxA-20762 } \\
\text { (Borić, 2011) }\end{array}$ & $8125 \pm 45$ & $7685 \pm 64$ & $6645-6430$ & $\begin{array}{l}20,26,27, \\
29,30,31\end{array}$ & lingual & 9.92 \\
\hline Vlasac & $\mathrm{H} 341$ & Late Meso & & & & & 1 & buccal & 10.12 \\
\hline Vlasac & VL48 & Late Meso & & & & & 34 & lingual & 10.06 \\
\hline Vlasac & $\begin{array}{l}\mathrm{U} 222 \\
\mathrm{x} .18 \\
\end{array}$ & Late Meso & & & & & 2 & buccal & 9.54 \\
\hline Lepenski & LV28 & Meso-Neo & & & & - & 43 & buccal & 9.58 \\
\hline
\end{tabular}




\begin{tabular}{|c|c|c|c|c|c|c|c|c|c|}
\hline Vir & & & & & & & & & \\
\hline $\begin{array}{l}\text { Lepenski } \\
\text { Vir }\end{array}$ & LV79a & Meso-Neo & $\begin{array}{c}\text { OxA-25091 } \\
\text { (Bonsall et al., } \\
2015 \text { ) } \\
\end{array}$ & $7605 \pm 38$ & $7119 \pm 74$ & $6220-5805$ & 33 & buccal & 9.69 \\
\hline $\begin{array}{l}\text { Hajdučka } \\
\text { Vodenica }\end{array}$ & HV16 & Meso-Neo & & & & & 36 & lingual & 9.54 \\
\hline $\begin{array}{l}\text { Hajdučka } \\
\text { Vodenica }\end{array}$ & HV19 & Meso-Neo & & & & & 37 & buccal & 9.58 \\
\hline $\begin{array}{l}\text { Hajdučka } \\
\text { Vodenica }\end{array}$ & HV13 & Meso-Neo & $\begin{array}{c}\text { AA-57773 } \\
\text { (Borić, 2011) }\end{array}$ & $7435 \pm 70$ & $6995 \pm 83$ & $6020-5720$ & 17 & lingual & 9.56 \\
\hline Padina & PAD4 & Meso-Neo & $\begin{array}{c}\text { AA-57769 } \\
\text { (Ottoni et al., } \\
2021)\end{array}$ & $7518 \pm 72$ & $7078 \pm 85$ & $6080-5745$ & 48 & buccal & 9.73 \\
\hline Padina & PAD5 & Meso-Neo & $\begin{array}{c}\text { AA-57770 } \\
(\text { Borić, 2011) }\end{array}$ & $7598 \pm 72$ & $7158 \pm 85$ & $6230-5845$ & 15 & buccal & 8.10 \\
\hline Vlasac & $\begin{array}{l}\mathrm{U} 24 \\
\mathrm{x} .30 \\
\end{array}$ & Meso-Neo & & & & & 32 & lingual & 9.97 \\
\hline Vlasac & H53 & Meso-Neo & $\begin{array}{c}\text { OxA-16544 } \\
\text { (Borić et al., } \\
2014 \text { ) }\end{array}$ & $7035 \pm 40$ & - & $6015-5805$ & $3,28,29$ & lingual & 10.04 \\
\hline $\begin{array}{l}\text { Lepenski } \\
\text { Vir }\end{array}$ & LV4 & E. Neolithic & & & & & 33 & buccal & 9.64 \\
\hline $\begin{array}{l}\text { Lepenski } \\
\text { Vir }\end{array}$ & LV73 & E. Neolithic & $\begin{array}{c}\text { BA-10652 } \\
\text { (Borić et al., } \\
\text { 2018) }\end{array}$ & $7265 \pm 30$ & $6973 \pm 48$ & $5980-5735$ & 34 & buccal & 9.69 \\
\hline $\begin{array}{l}\text { Lepenski } \\
\text { Vir }\end{array}$ & LV8 & E. Neolithic & $\begin{array}{c}\text { AA-58319 } \\
\text { OxA-25207 } \\
\text { (Borić et al., } \\
2018 \text { ) }\end{array}$ & $\begin{array}{l}6825 \pm 51 \\
7097 \pm 36\end{array}$ & $\begin{array}{l}6690 \pm 54 \\
6984 \pm 39\end{array}$ & $\begin{array}{l}5715-5520 \\
5985-5750\end{array}$ & 44 & lingual & 9.69 \\
\hline $\begin{array}{c}\text { Lepenski } \\
\text { Vir }\end{array}$ & LV32A & E. Neolithic & $\begin{array}{c}\text { OxA-5828 } \\
\text { (Bonsall et al., } \\
\text { 1997) } \\
\end{array}$ & $7270 \pm 90$ & $7032 \pm 95$ & $6065-5730$ & $42,43,36$ & buccal & 9.77 \\
\hline $\begin{array}{l}\text { Lepenski } \\
\text { Vir }\end{array}$ & LV17 & E. Neolithic & $\begin{array}{c}\text { AA-58320 } \\
\text { (Bonsall et al., } \\
\text { 2015) }\end{array}$ & $7007 \pm 48$ & $6787 \pm 53$ & $5775-5565$ & 15 & lingual & 9.10 \\
\hline Padina & PAD30 & Bronze Age & $\begin{array}{c}\text { PSU-2379 } \\
\text { (Lazaridis et } \\
\text { al., in press) }\end{array}$ & & & $2140-1765$ & 47 & buccal & 9.69 \\
\hline Velesnica & $2 \mathrm{~A}$ & $\mathrm{Neo}$ & $\begin{array}{c}\text { OxA-19191 } \\
\text { (Bonsall et al., } \\
\text { 2015) }\end{array}$ & $7409 \pm 38$ & $7196 \pm 47$ & $6220-5930$ & 8 & lingual & 9.74 \\
\hline Velesnica & $2 \mathrm{D}$ & E. Neolithic & $\begin{array}{c}\text { OxA-19210 } \\
\text { (Bonsall et al., } \\
\text { 2015) }\end{array}$ & $7327 \pm 38$ & $7183 \pm 42$ & $6215-5925$ & 9 & lingual & 7.2 \\
\hline Gîrlestj & & E. Neolithic & & & & & 2 & lingual & 8.22 \\
\hline $\begin{array}{l}\text { Lepenski } \\
\text { Vir }\end{array}$ & LV30 & Medieval & $\begin{array}{c}\text { OxA-25218 } \\
\text { (Bonsall et al., } \\
2015) \\
\end{array}$ & $427 \pm 23$ & & $\begin{array}{c}\text { AD1440- } \\
1490\end{array}$ & 16 & lingual & 9.67 \\
\hline
\end{tabular}

Type I. Size, shape, morphology and bimodal distribution that characterize granules of this type are encountered in Europe only in the members of the plant tribe Triticeae (Poaceae family) and considered diagnostic features for taxonomic identification (Henry and Piperno, 2008; Stoddard, 1999; Yang and Perry, 2013). Such distribution involves the presence of large granules (AType), mostly with a clear, round to sub-oval in $2 \mathrm{D}$ shape, ranging between 21.1 and $62.7 \mu \mathrm{m}$ in maximum dimensions (mean size of $41.9 \mu \mathrm{m}$ ), lenticular 3D shape with equatorial groove always visible, a central hilum and high density of deep lamellae concentrated in the mesial part; and small granules (B-Type) with round/sub-oval shapes, a central hilum, generally smaller than $10 \mu \mathrm{m}$ (Geera et al., 2006; Stoddard, 1999; Yang and Perry, 2013). A-Type granules possess diagnostic features while smaller B-Type granules are rarely diagnostic to taxa (Yang and Perry, 2013). However, in our archaeological population, variability in the proportion and dimension of small B-type granules has been noticed, resulting in a unimodal granule size distribution without a clear distinction between A and B granules in some cases. Several studies (Howard et al., 2011; Stoddard and Sarker, 2000) suggested that this characteristic is common in the species of the genus Aegilops of the Triticeae tribe and can be attributed to both environment (Blumenthal et al., 1995, 1994) and genetics (Stoddard and Sarker, 2000). A unimodal starch granule size distribution characterized by normal A-type granules and a lack/reduced quantity of 
B-type granules was also evident in our modern reference collection of local Aegilops species (Fig. 6). Based on these observations, Type I category was further divided into two subtypes (Ia and Ib). In subtype Ia, B-Type granules are small, dimensionally uniform (up to $12 \mu \mathrm{m}$ ) and round in shape (fig.6). Conversely, subtype Ib is characterized by a high variation in starch granule size not allowing for a distinction between A and B-type granule, resulting in a unimodal distribution (Fig.9).

Type I ( Ia and Ib) is very common in the analyzed samples (Table 2), as already emphasized in our earlier study albeit in different quantities (24). These starch granules were documented, often lodged in the amyloplast, in most of the analyzed Mesolithic individuals (5 for EM, 16 for $\mathrm{LM}, 5$ for $\mathrm{M} / \mathrm{N}$ ), and in five EN individuals of our population (Table 2). A-Type granules recovered in EM and most of the LM individuals were very large, mostly with a clear, round shape, central hilum, and high density of deep lamellae mainly concentrated in the mesial part of the granules. Based on literature (Henry et al., 2011; Yang and Perry, 2013) and our extensive experimental and statistical results on modern botanical collection (Tables 4,5; Figs. 6, 7, 9), we confirm that these characteristics are consistent with A-Type granules of most species of the Triticeae tribe.

Subtype Ia. A few LM and M/N individuals (for example, HV11 and 16, H53, 64.x11, H327, H232) yielded a combination of oval A-Type granules and uniformly small, round B-Type granules (Fig. $4 \mathrm{~m}$ ). Our previous claims that this pattern is a recognizable feature of the domestic species of the tribe Triticeae (e.g., Triticum spp./Hordeum spp.) (Figs. 6,9) (Cristiani et al., 2016) are now further supported by a new morphometric analysis of both domestic and wild Triticeae species (Fig.9). Moreover, in the same individuals, A-Type granules could show cratered appearance (Fig. 4y). Similarly, in the EN individuals, lenticular and oval/sub-oval AType granules with equatorial groove and, an often visible, cratered surface are always associated with very small and uniformly shaped B-Type granules. Type A granules appear damaged in few EN individuals, which may be linked to enzymatic digestion (salivary amylase) although plant food processing could also result in starch damage based on experimental results (Ma et al. 2019; Zupancich et al. 2019)

Subtype $I b$. Significant unevenness in granule dimensions and shape was recorded in the EM and most of the LM individuals (e.g., PAD9 and VL45). Granules in this subtype are dimensionally variable and their shapes can range from round to oval (Fig. 4b). The well-known limitations in the inclusion, preservation, and recovery of plant debris in dental calculus (Radini et al., 2017) might be responsible for not recognizing this subtype previously. 


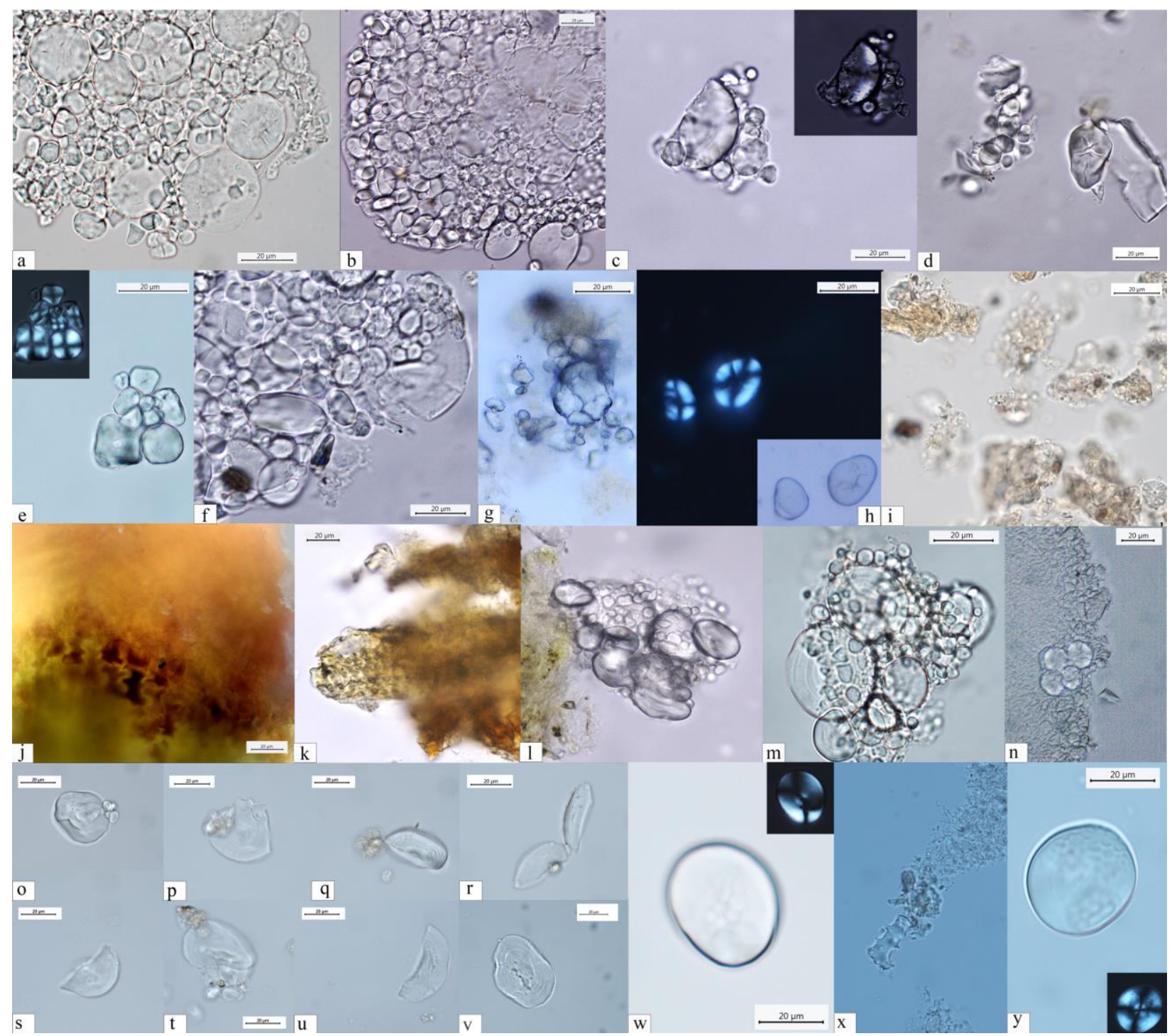
Figure 4. Starch granules from Mesolithic and Neolithic dental calculus. Early Mesolithic: (a) Type Ib (PAD11); (b) Type Ib (PAD9); (c) Type Ib (PAD11); (d) Type V (PAD12); (e) Type III (PAD11); (f) Type Ib (PAD15); Late Mesolithic: (g) Type II (VL82c); (h) Type IV (VL31); (i) Type VI (VL70); (j, k) Multicellular structures of long cells embedded in dental calculus (HV25/26, VL70); (I) Type Ia (HV11); Mesolithic-Neolithic: (m) Type Ia (HV16). Neolithic: (n) Type III (LV32a); (o-v) Damaged Type I granules (A-Type granules) (VEL-2D); (w) Type I (A-Type granule) (VEL-2D); (x) Single dendritic cell (Gârleşti); (y) Type I (A-Type granule) (VEL-2D) (VEL-2A). 


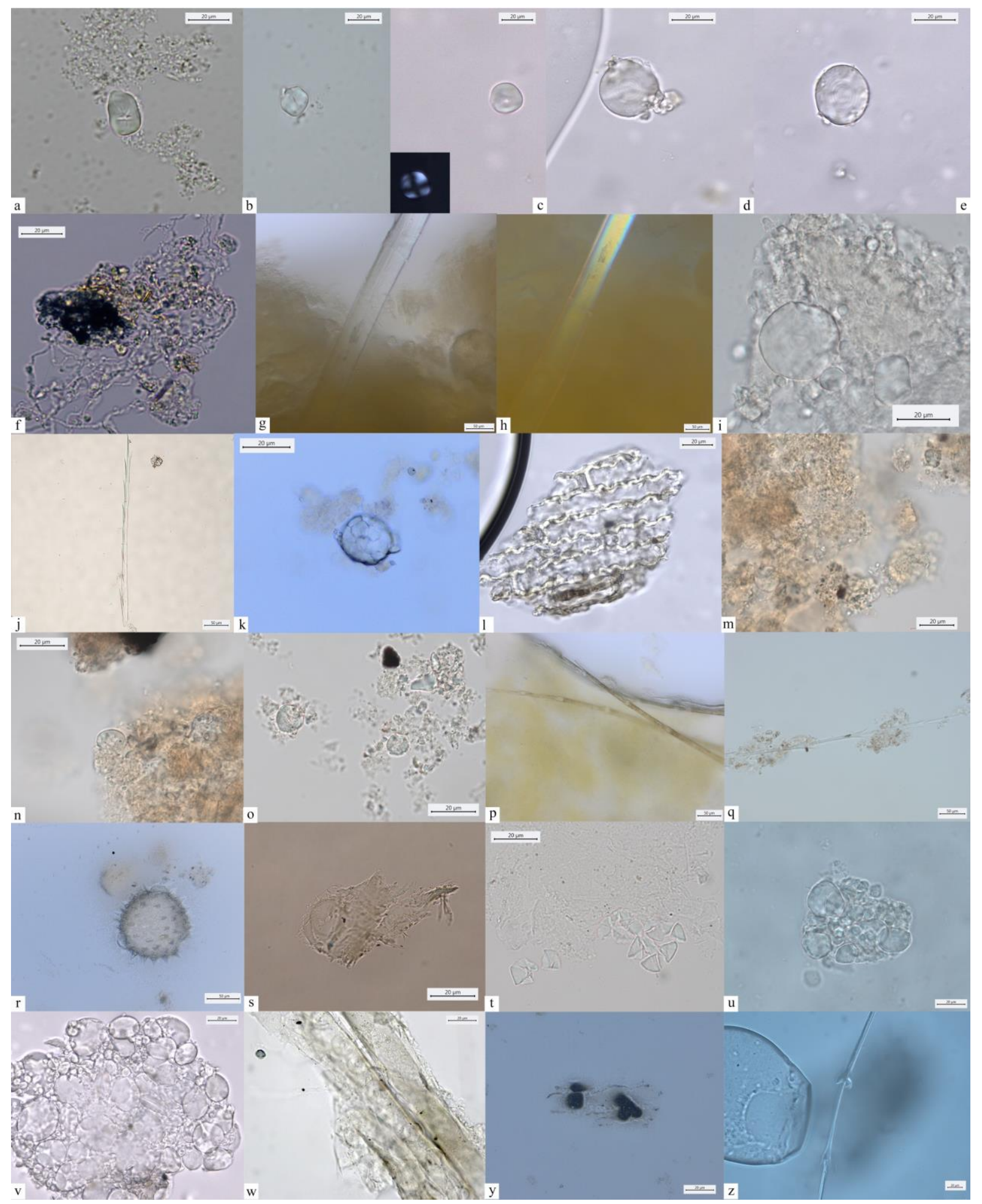

Figure 5. Other dietary and non-dietary debris found in Mesolithic dental calculus from the Danube Gorges. Early Mesolithic: (a) Type V (PAD11); (b,c) Type III (PAD12); (d) Type I (AType granule) (VEL-2D) (PAD12); (e) Type I (A-Type granule) (PAD12); (f) Smoke particle (LV50); (g, h) Plant fiber embedded in calculus (PAD16); (i) Type Ib (PAD9); (j) Feather barbule embedded in calculus (PAD9); Late Mesolithic: (k) Type II (PAD2); (I) Polylobate phytolith (US64 x.11); (m) Phytoliths (VL79); (n-p) Type VI (VL70,VL83); (q) Feather barbules embedded in calculus (HV25/26); (r) Feather barbule embedded in calculus (VL80a); (s) Echinate pollen grain in calculus (VL83); (t) Plant tissue (LV79a); (u) Type II (VL43); (v) 
Type Ia (HV11); Mesolithic/Neolithic: (w) Type I (HV16); (x) Wood particle (PAD4); (y) Phytoliths (LV28); (z) Feather barbule (PAD4).

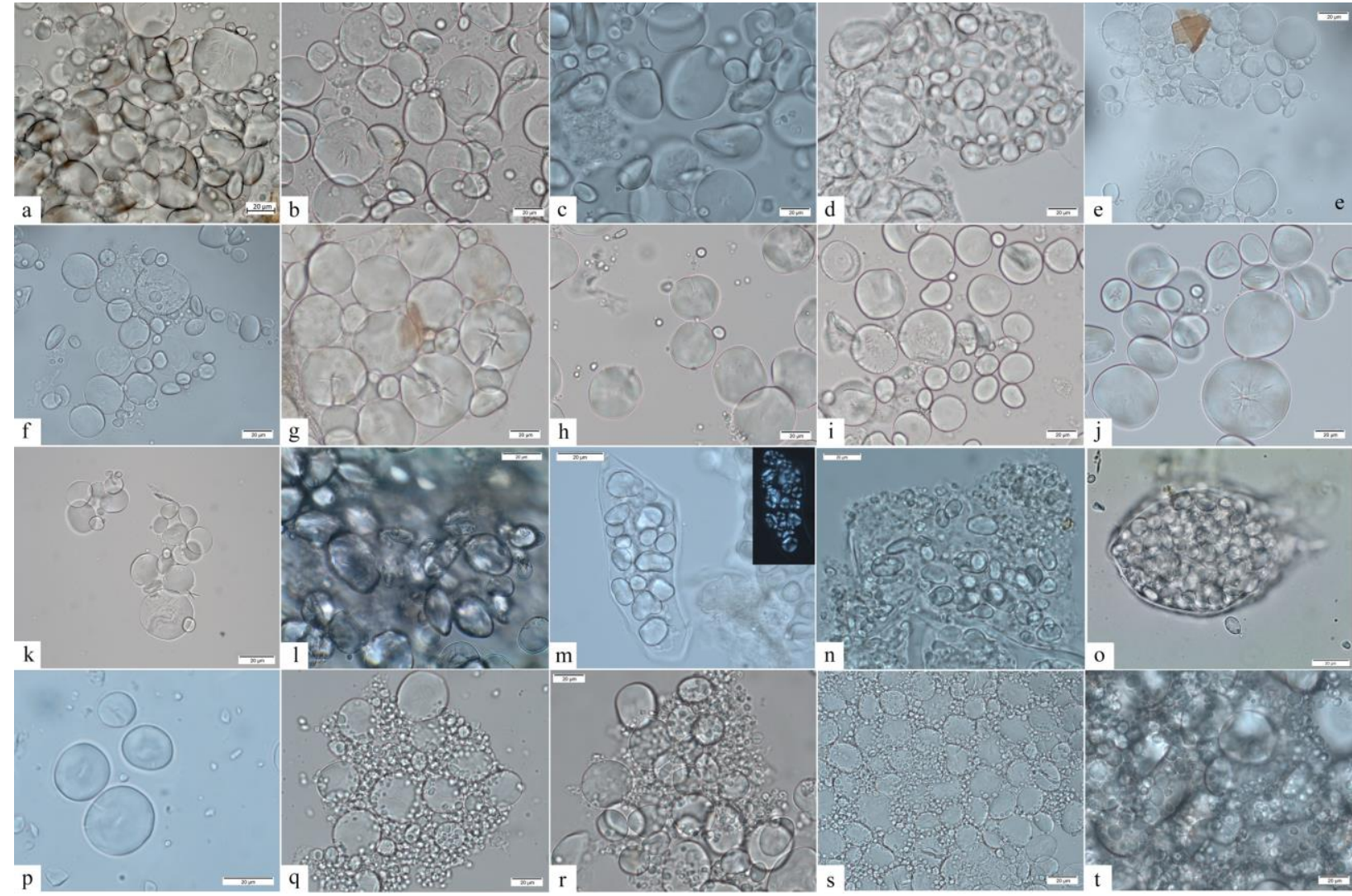

Figure 6. Starch granule morphological variability within the species of the genus Aegilops and domestic species of the Triticeae tribe. a) Aegilops cylindrica; b) A. neglecta; c) A. speltoides tauschii; d) A. caudata; e) A. triuncialis; f) A. comosa; g) A. uniaristata; h) A. ventricosa; i) A. geniculata; j) A. crassa; k) A. peregrina; l) Elymus caninus; m) Bromus tectorum; n) Agropyron pungens; o) A. farctus; p) Dasypyron villosum; q) Triticum monococcum; r) Hordeum vulgare; s) T. dicoccum; t) T. aestivum. 


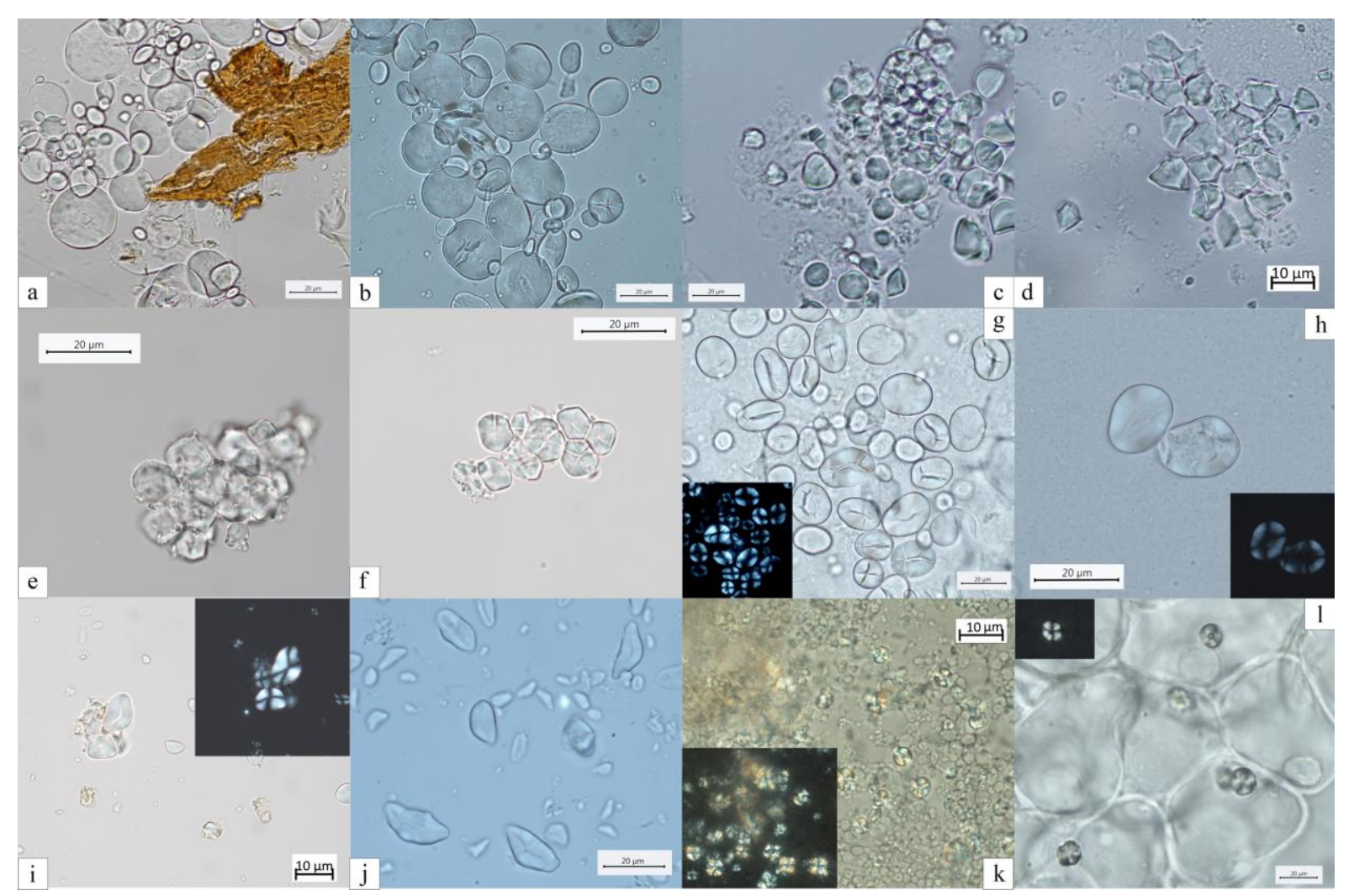

Figure 7. Experimental reference for starch granules identified in the dental calculus and GSTs. a) Aegilops triuncialis; b) A. crassa; c,d) Avena strigosa; e,f) Setaria italica; g) Vicia cracca; h) V. sylvatica; i) Quercus pubescens; j) Q. robur; k) Q. colurna; l) Cornus mas.

Type II. Starch granules attributed to this type consist of large aggregates as well as clustered polyhedral/irregular granules (main axis ranging from 5 to $15 \mu \mathrm{m}$ ). They were retrieved from 10 individuals (2 EM, $11 \mathrm{LM}, 2 \mathrm{M} / \mathrm{N}$, and $3 \mathrm{EN}$ ) (Table 2) (Fig. 4g). The identification of archaeological specimens is based on published records (Lippi et al., 2015) and our experimental reference (Avena barbata L., A. strigosa Schreb., A. fatua L.) (Fig. 7). Granules of this morphotype were grouped in the tribe Aveneae/Poeae based on the fact that such large aggregates are found mostly in the genus Avena L. (oat), which is very common in the region.

Type III. Starch granules attributed to this type are characterized by a polyhedral to subpolyhedral 3D morphology, a central hilum, and fine cracks. They were recovered in 16 individuals (5 for EM, 16 for LM, 2 for M/N, and 1 for EN) (Table 2) (Fig. 4e, Fig.5b and c). These features are consistent with starch granules of the tribe Paniceae of the grass family Poaceae and very well known in ancient starch research (Madella et al., 2016). In our sample, starch granules assigned to type III reach $21 \mu \mathrm{m}$ of maximum width, which falls within the size range found in several species of Setaria spp., Panicum spp., and Echinochloa spp. (Lucarini et al., 2016) (Fig. 7). Small granules characterized by a round to sub-polyhedral 3D morphology, and a central open hilum have been attributed to the tribe Andropogoneae and are here described under the general group of "millets" as is common practice (Madella et al., 2016).

Type IV. Starch granules of this type are identified in 10 individuals ( 2 EM, 8 LM, 1 M/N, and $2 \mathrm{EN}$ ) and are recovered above 6 granules per specimen, with the exception of the only EN 
individual (Table 2). Diagnostic morphological characteristics for type IV granules are known in ancient starch research and include a reniform shape in 3D, a collapsed/sunken hilum forming a deep fissure along almost the entire granule, and a size ranging between 12 to $35 \mu \mathrm{m}$ (Henry et al., 2011). Small cracks were observed departing from such hilum and were very evident under cross-polarized light. In most cases the extinction cross was very bright and showed several lateral arms diverging from the hilum in correspondence with the cracks (Fig. 4H). Moreover, lamellae were visible towards the outer part of the granules. All these features are very peculiar and diagnostic of starch granules included in the species of the plant family Fabaceae (Henry et al., 2011), which is mostly known for its several edible domesticated species of legumes (e.g. Lens culinaris Medikus, Vicia faba L., and Pisum sativum L.), but also has a number of wild edible such as vetches (Vicia spp.). While many edible species of the family Fabaceae grow in the Balkans (e.g. Vicia sativa L., V. cracca L., V. hirsuta, V. ervilia, Lathyrus pratensis L., L. sylvestris $\mathrm{L}$.), an identification at species or genus was not possible due to overlaps in shape and size of starch granules at tribe level, which were observed in our modern reference collection (Fig. 7).

Type V. Few starch granules attributed to this type have been identified in 8 individuals (2 EM, 5LM, 1MN) (Fig. 4d, 5a and Table 2). Starch granules reach $23 \mu \mathrm{m}$ in length and are mostly triangular with round corners and/or have an irregular oval shape (Fig. 5a). Overall, lamellae can rarely be visible. The granules show a linear fissure in the center and sometimes the hilum appears as a wide depression. Under polarized light, the hilum is mostly centric while the extinction cross has bent arms. This type was found to have a very close visual match with the starch found in acorns of oaks (Quercus spp.), a Fagaceae member and well known in ancient starch research (Liu et al., 2010) (Fig. 7i,j).

Type VI. Granules ascribed to this type have been identified in two individuals (1 LM, $1 \mathrm{M} / \mathrm{N}$ ) (Table 2). They are characterized by a round 3D morphology and a central hilum, which appears as a wide depression, and no lamellae or facets (Fig. 4i, Fig. 5n-p). Zarrillo and Kooyman (2006) consider these morphological features diagnostic of some species of drupes and berries. In our sample, starch granules of this morphotype can reach $12 \mu \mathrm{m}$ of maximum width, which is beyond species of berries and drupes in the Rosaceae family known in literature (Zarrillo and Kooyman 2006) and in our modern reference (e.g. Prunus spinosa L.). Based on our experimental record, we assign type VI to species of the family Cornaceae (e.g. Cornus mas) (Fig. 7), the remains of which are documented at Vlasac (Filipović et al. 2010).

In addition to starch granules, 42 phytoliths were retrieved in 24 individuals (EM=4; $L M=13$; $\mathrm{MN}=2 ; \mathrm{N}=5$ ). Mostly, short cells, commonly produced in leaves, stems and inflorescences, were identified (14) and attributed to Pooid grasses. Multicellular structures of long cells were identified in Mesolithic individuals (HV25/26, VL70, VL79, U222) (Fig. 4j,k; Fig. 5m). Of particular relevance is the recovery of multicellular phytoliths with dendritic appearance. It was observed at least in one case, still embedded in the dental calculus (Fig.4k). Single or multicellular dendritic structures were also identified in Neolithic individuals (VEL-2D and Gîrlestj) (Figs. 4w,x) (Fig. 4w). A single polylobate cell was found in one Late Mesolithic individual (US64 x.11). With the exception of dendritic structures, characterizing grass 
343 inflorescences, different non-dietary reasons may be suggested for the inclusion of phytoliths in 344 dental calculus (i.e., accidental ingestion, inhalation, dust in the environment generated by the use of grasses in a variety of activities and uses, such as flooring, kindling etc.) (Norström et al., 2019).

Table 2. Details of the micro-debris (starch granules and other micro-remains) found in the archaeological dental calculus samples ( $\mathrm{PO}=\mathrm{Pollen} ; \mathrm{W}=\mathrm{Wood} ; \mathrm{Ch}=$ Microcharcoal/burnt debris; $\mathrm{Gr}=\mathrm{Grit}$; P=Phytoliths; FE=Feathers; FI=Fibers; FU=Fungi; $\mathrm{S}=$ Smoke $)(\mathrm{n}=51)$.

\begin{tabular}{|c|c|c|c|c|c|c|c|c|c|c|c|}
\hline & Site & $\begin{array}{l}\text { Burial } \\
\text { label }\end{array}$ & $\begin{array}{c}\text { Chrono- } \\
\text { cultural } \\
\text { attribution }\end{array}$ & $\begin{array}{c}\text { Type I } \\
\text { Tritic } \\
\text { eae }\end{array}$ & $\begin{array}{c}\text { Type II } \\
\text { Aveneae }\end{array}$ & $\begin{array}{c}\text { Type III } \\
\text { Panicea } \\
\text { e } \\
\end{array}$ & $\begin{array}{l}\text { Type IV } \\
\text { Fabeae }\end{array}$ & $\begin{array}{c}\text { Type V } \\
\text { Fagacea } \\
\text { e } \\
\end{array}$ & $\begin{array}{c}\text { Type VI } \\
\text { Cornacea } \\
\text { e } \\
\end{array}$ & Indet. & Other \\
\hline 1 & Padina & PAD20 & Early Meso & & & 7 & 4 & & & 3 & $\begin{array}{c}1 \mathrm{P} / 10 \mathrm{FI} / \\
2 \mathrm{FE} / 2 \mathrm{~W} / \\
1 \mathrm{Ch} / \mathrm{Gr}\end{array}$ \\
\hline 2 & Padina & PAD25 & Early Meso & & & 1 & & & & & $\begin{array}{c}1 \mathrm{P} / 1 \mathrm{Ch} / \\
\mathrm{Gr}\end{array}$ \\
\hline 3 & Padina & PAD15 & Early Meso & $>100$ & 4 & & 6 & & & & $\begin{array}{c}1 \mathrm{P} / 4 \mathrm{PO} / \\
1 \mathrm{~W} / 1 \mathrm{Ch} / \\
\mathrm{Gr}\end{array}$ \\
\hline 4 & Padina & PAD16a & Early Meso & & & 20 & & & & 3 & $\begin{array}{l}1 \mathrm{P} / 10 \mathrm{FI} / \\
8 \mathrm{Ch} / \mathrm{Gr}\end{array}$ \\
\hline 5 & Padina & PAD9 & Early Meso & $>200$ & & & & & & & $2 \mathrm{FI} / 2 \mathrm{FE}$ \\
\hline 6 & Padina & PAD11 & Early Meso & $>100$ & & 8 & & 1 & & & \\
\hline 7 & Padina & PAD12 & Early Meso & 36 & & 12 & & 1 & & 1 & \\
\hline 8 & $\begin{array}{c}\text { Lepenski } \\
\text { Vir }\end{array}$ & LV50 & Early Meso & & 1 & & & & & 1 & 1FI;S \\
\hline 9 & $\begin{array}{c}\text { Lepenski } \\
\text { Vir }\end{array}$ & LV20 & Early Meso & 4 & & & & & & 1 & \\
\hline 10 & Padina & PAD2 & Late Meso & 13 & 1 & 7 & 1 & & & & $\begin{array}{l}1 \mathrm{PO} / 1 \mathrm{FI} \\
/ 2 \mathrm{FE} / 2 \mathrm{~W} \\
/ 1 \mathrm{Ch} / \mathrm{Gr}\end{array}$ \\
\hline 11 & $\begin{array}{l}\text { Hajdučka } \\
\text { Vodenica }\end{array}$ & $\begin{array}{c}\text { HV25/2 } \\
6\end{array}$ & Late Meso & 5 & & 15 & & & & 1 & $\begin{array}{c}2 \mathrm{P} / 1 \mathrm{PO} / \\
2 \mathrm{FI} / 3 \mathrm{FE} / \\
1 \mathrm{Ch} / 3 \mathrm{~F} \\
\mathrm{U} / \mathrm{Gr}\end{array}$ \\
\hline 12 & $\begin{array}{l}\text { Hajdučka } \\
\text { Vodenica }\end{array}$ & HV29 & Late Meso & & 5 & & 3 & & & 5 & $\begin{array}{c}3 \mathrm{P} / 1 \mathrm{PO} / \\
1 \mathrm{FI} / 1 \mathrm{FE} / \\
13 \mathrm{~W} / 1 \mathrm{~F} \\
\mathrm{U} / \mathrm{Gr} \\
\end{array}$ \\
\hline 13 & $\begin{array}{l}\text { Hajdučka } \\
\text { Vodenica }\end{array}$ & HV8 & Late Meso & & 1 & & & & & & \\
\hline 14 & $\begin{array}{l}\text { Hajdučka } \\
\text { Vodenica }\end{array}$ & HV11 & Late Meso & $>100$ & 8 & 1 & & & & & \\
\hline 15 & $\begin{array}{l}\text { Hajdučka } \\
\text { Vodenica }\end{array}$ & $\begin{array}{c}\text { HV } \\
\text { profil A }\end{array}$ & Late Meso & & & 14 & & & & 1 & $\begin{array}{c}3 \mathrm{PO} / 1 \mathrm{FI} \\
/ 2 \mathrm{FE} / 3 \mathrm{~W} \\
/ 1 \mathrm{Ch} / 1 \mathrm{~F} \\
\mathrm{U} / \mathrm{Gr}\end{array}$ \\
\hline 16 & $\begin{array}{l}\text { Hajdučka } \\
\text { Vodenica }\end{array}$ & HV30 & Late Meso & & & 1 & & & & & \\
\hline 17 & Vlasac & $\begin{array}{l}\text { U222 } \\
\text { x.18 }\end{array}$ & Late Meso & & & & 2 & & & & $1 \mathrm{P}$ \\
\hline 18 & Vlasac & U326 & Late Meso & $>60$ & & & & & & 1 & $1 \mathrm{P}$ \\
\hline 19 & Vlasac & VL82c & Late Meso & 4 & 23 & 7 & 2 & & & 5 & $\begin{array}{c}1 \mathrm{P} / 3 \mathrm{PO} / \\
1 \mathrm{FE} / 1 \mathrm{~W} / \\
1 \mathrm{Ch} / \mathrm{Gr}\end{array}$ \\
\hline 20 & Vlasac & VL2 & Late Meso & 2 & 12 & & & & & & $\begin{array}{l}2 \mathrm{P} / 1 \mathrm{PO} / \\
2 \mathrm{FI} / 1 \mathrm{FE} / \\
2 \mathrm{FU} / \mathrm{Gr}\end{array}$ \\
\hline 21 & Vlasac & VL80a & Late Meso & 3 & 15 & 5 & 5 & 1 & & & $\begin{array}{c}1 \mathrm{P} / 4 \mathrm{FE} / \\
1 \mathrm{~W} / 1 \mathrm{Ch} / \\
1 \mathrm{FU} / \mathrm{Gr}\end{array}$ \\
\hline 22 & Vlasac & VL55 & Late Meso & & & 6 & & & & 1 & $\begin{array}{l}1 \mathrm{P} / 1 \mathrm{PO} / \\
1 \mathrm{FI} / 1 \mathrm{~W} / \\
1 \mathrm{FU} / \mathrm{Gr}\end{array}$ \\
\hline 23 & Vlasac & VL74 & Late Meso & & & 1 & & & & 1 & $\begin{array}{c}1 \mathrm{P} / 3 \mathrm{PO} / \\
17 \mathrm{FI} / 1 \mathrm{C} \\
\mathrm{h} / \mathrm{Gr}\end{array}$ \\
\hline 24 & Vlasac & VL83 & Late Meso & 6 & & 8 & 1 & & & & $1 \mathrm{P} / 1 \mathrm{PO} /$ \\
\hline
\end{tabular}




\begin{tabular}{|c|c|c|c|c|c|c|c|c|c|c|c|}
\hline & & & & & & & & & & & $\begin{array}{c}1 \mathrm{FE} / 2 \mathrm{~W} / \\
5 \mathrm{Ch} / \mathrm{Gr}\end{array}$ \\
\hline 25 & Vlasac & VL43 & Late Meso & $>200$ & 12 & 1 & & 1 & & 2 & $\begin{array}{c}2 \mathrm{FE} / 1 \mathrm{~W} / \\
2 \mathrm{Ch} / 1 \mathrm{~F} \\
\mathrm{U} / \mathrm{Gr}\end{array}$ \\
\hline 26 & Vlasac & VL31 & Late Meso & & & 18 & 3 & & & 3 & $\begin{array}{c}4 \mathrm{PO} / 5 \mathrm{~F} \\
\mathrm{E} / 1 \mathrm{Ch} / 2 \\
\mathrm{FU} / \mathrm{Gr}\end{array}$ \\
\hline 27 & Vlasac & VL45 & Late Meso & 23 & 8 & 20 & & 1 & & 14 & $\begin{array}{l}1 \mathrm{PO} / 2 \mathrm{~F} \\
\mathrm{E} / 2 \mathrm{Ch}\end{array}$ \\
\hline 28 & Vlasac & VL70 & Late Meso & 3 & & 3 & & 1 & 14 & & $\begin{array}{c}4 \mathrm{P} / 1 \mathrm{FI} / 7 \\
\mathrm{Ch}\end{array}$ \\
\hline 29 & Vlasac & VL79 & Late Meso & & & & & & & & $1 \mathrm{P} / 2 \mathrm{FI}$ \\
\hline 30 & Vlasac & U44 & Late Meso & 3 & & & 2 & & & & \\
\hline 31 & Vlasac & H232 & Late Meso & $<100$ & 4 & 1 & & & & & $\begin{array}{c}1 \mathrm{PO} / 1 \mathrm{~F} \\
\mathrm{E}\end{array}$ \\
\hline 32 & Vlasac & U115 & Late Meso & & & & & 1 & & & \\
\hline 33 & Vlasac & $\begin{array}{l}\text { U64 } \\
\text { x.11 }\end{array}$ & Late Meso & $>200$ & 10 & 32 & & & & 4 & $\begin{array}{c}2 \mathrm{P} / 4 \mathrm{FI} / 2 \\
\mathrm{FE} / 3 \mathrm{Ch} / \\
1 \mathrm{FU}\end{array}$ \\
\hline 34 & Vlasac & H341 & Late Meso & 1 & & & & & & & \\
\hline 35 & $\begin{array}{c}\text { Lepenski } \\
\text { Vir }\end{array}$ & LV28 & Meso-Neo & 4 & & 3 & 1 & & & 6 & $\begin{array}{c}2 \mathrm{P} / 2 \mathrm{PO} / \\
1 \mathrm{FE} / 2 \mathrm{~W} / \\
4 \mathrm{Ch} / \mathrm{Gr}\end{array}$ \\
\hline 36 & $\begin{array}{l}\text { Hajdučka } \\
\text { Vodenica }\end{array}$ & HV16 & Meso-Neo & $>200$ & & & & & & & $1 \mathrm{FU}$ \\
\hline 37 & $\begin{array}{l}\text { Hajdučka } \\
\text { Vodenica }\end{array}$ & HV19 & Meso-Neo & 1 & & & & & & & $1 \mathrm{FE}$ \\
\hline 38 & $\begin{array}{l}\text { Hajdučka } \\
\text { Vodenica }\end{array}$ & HV13 & Meso-Neo & & 1 & & & & & & \\
\hline 39 & Padina & PAD4 & Meso-Neo & & & & & 1 & & 7 & $\begin{array}{c}2 \mathrm{PO} / 1 \mathrm{FI} \\
/ 3 \mathrm{FE} / 4 \mathrm{~W} \\
/ 2 \mathrm{Ch} / 1 \mathrm{~F} \\
\mathrm{U} / \mathrm{Gr}\end{array}$ \\
\hline 40 & Padina & PAD5 & $\mathrm{Meso} / \mathrm{Neo}$ & 6 & & & & & & & \\
\hline 41 & Vlasac & $\begin{array}{l}\text { U24 } \\
\text { x.30 }\end{array}$ & Meso-Neo & & & & & & 10 & & $1 \mathrm{P} / 2 \mathrm{Ch}$ \\
\hline 42 & Vlasac & H53 & Meso-Neo & 22 & $>200$ & 5 & & & & & $1 \mathrm{FE} / 1 \mathrm{~W}$ \\
\hline 43 & $\begin{array}{c}\text { Lepenski } \\
\text { Vir }\end{array}$ & LV4 & $\mathrm{Neo}$ & 1 & 3 & & & & & 1 & \\
\hline 44 & $\begin{array}{c}\text { Lepenski } \\
\text { Vir }\end{array}$ & LV73 & $\mathrm{Neo}$ & 12 & 9 & & & & & 1 & $\begin{array}{c}7 \mathrm{P} / 2 \mathrm{PO} / \\
17 \mathrm{FI} / 1 \mathrm{~F} \\
\mathrm{E} / 3 \mathrm{FU} / \mathrm{G} \\
\mathrm{r} \\
\end{array}$ \\
\hline 45 & $\begin{array}{c}\text { Lepenski } \\
\text { Vir }\end{array}$ & LV8 & Neo & 11 & & & 4 & & & & $1 \mathrm{~W}$ \\
\hline 46 & $\begin{array}{c}\text { Lepenski } \\
\text { Vir }\end{array}$ & LV32A & $\mathrm{Neo}$ & & 8 & $>200$ & & & & & $1 \mathrm{P} / 2 \mathrm{FE}$ \\
\hline 47 & $\begin{array}{c}\text { Lepenski } \\
\text { Vir }\end{array}$ & LV17 & $\mathrm{Neo}$ & 14 & & & 5 & & & & \\
\hline 48 & Velesnica & $2 \mathrm{~A}$ & $\mathrm{Neo}$ & & & & & & & & $4 \mathrm{FU}$ \\
\hline 49 & Velesnica & $2 \mathrm{D}$ & $\mathrm{Neo}$ & 12 & & & & & & & $2 \mathrm{P} / 2 \mathrm{FU}$ \\
\hline 50 & Gârleşti & & $\mathrm{Neo}$ & 1 & & & & & & & $1 \mathrm{P} / 1 \mathrm{Ch}$ \\
\hline 51 & $\begin{array}{c}\text { Lepenski } \\
\text { Vir }\end{array}$ & LV30 & Medieval & & & 12 & 4 & & & & $\begin{array}{c}1 \mathrm{P} / 1 \mathrm{PO} / \\
4 \mathrm{Ch} / 1 \mathrm{~F} \\
\mathrm{U} / \mathrm{Gr}\end{array}$ \\
\hline & Total & & & $>1446$ & 324 & $>409$ & 43 & 8 & 24 & & 284 \\
\hline
\end{tabular}

Ground stone tools

354 Diagnostic use-wear and residues are identified on 44 GSTs from the site of Vlasac. Analyzed tools included functional categories such as handstones (e.g., grinders and crushers) as well as passive bases (anvils) (Table 3). All of the tools are made of sandstone, characterized grains ranging in size between 0.2 and $1 \mathrm{~mm}$ densely distributed within the matrix. The combination of different functional modifications (i.e., flattened surfaces, pitted areas, rounding, etc.) on the single specimens suggests the long and complex life-histories of the artefacts, often used in different activities. Within the tools displaying diagnostic use wear, a total of 17 GSTs have 
361 surfaces bearing functional areas positively associated with plant food processing (Table 3 and 362 Fig. 3). The analysis conducted at low magnification on these tools revealed macro-traces 363 resulting in levelled surface crystal grains, sometimes covered by spots of yellowish organic 364 film (sometimes striated) and white compacted powder (Fig. 4Z, Aa). At a high magnification, 365 high and low micro topographies of the GST surfaces are affected by a smooth domed, and 366 sometimes striated, micro polish (Fig. 4Bb, Cc). The aforementioned combination of use-wear 367 and macro residues are commonly associated with GSTs used as handstones for crushing and 368 grinding grass grains and/or fruits, such as hazelnuts and/or acorns in our experimental record 369 (Cristiani and Zupancich, 2020) (Fig. 8).

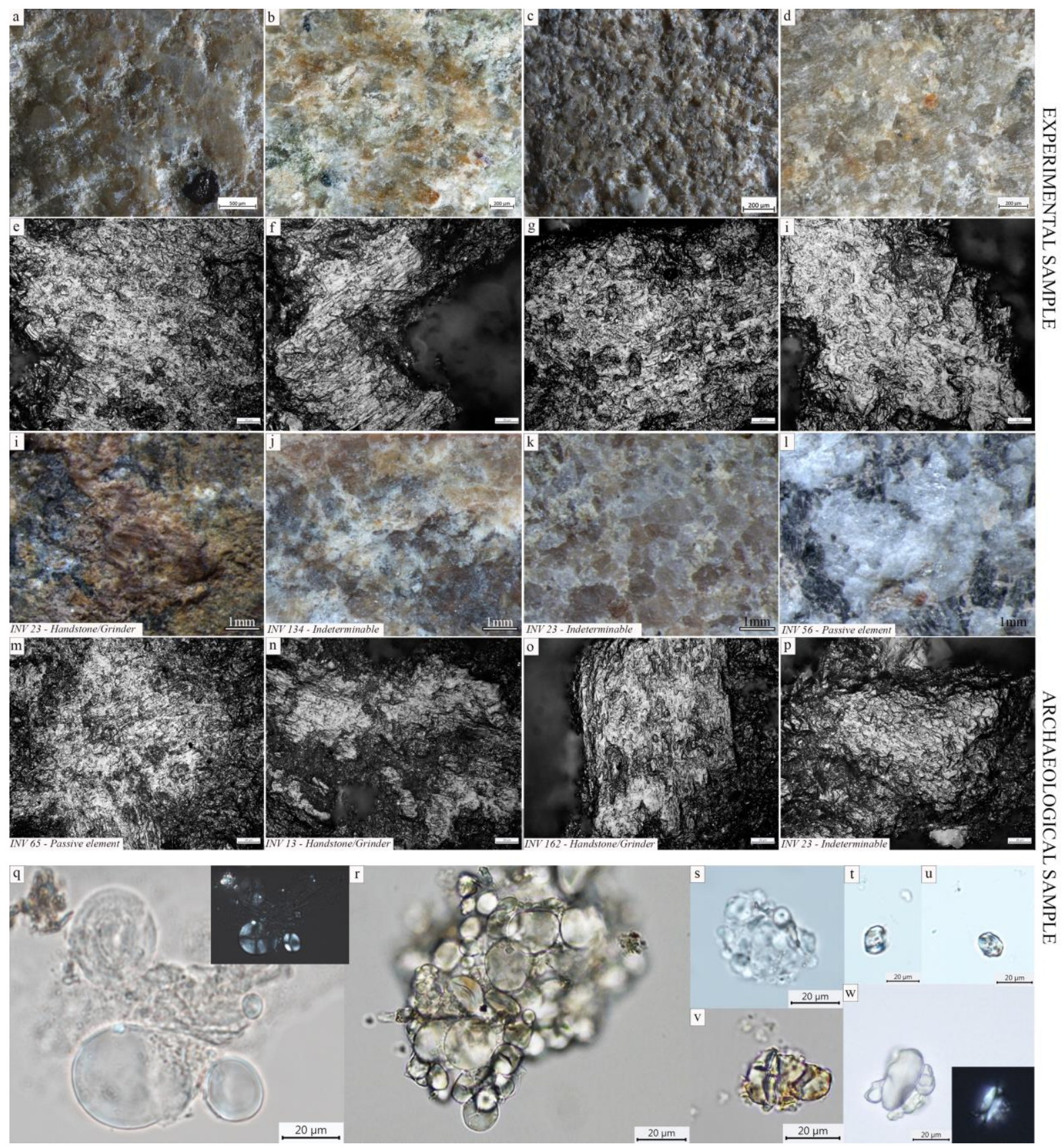

Figure 8. Experimental macro residues and micro polish associated with grass grains processing compared to macro residue and micro polish identified on archaeological GSTs from 
the site of Vlasac; a-e) yellowish organic film covering the crystal grains on experimental GSTs used to process oat (a), downy brome (b), wild grass grains, (c) and millet (d); smooth domed and flat micro polish developing over the high and low micro topographies associated with oat (Avena barbata) grinding; f) smooth flat and domed micro polish developing over the surface high and low micro topographies and characterized by narrow micro striations associated with grinding downy brome (Bromus tectorum L.); g) smooth flat micro polish developed over the high and low micro topographies characterized by sporadic narrow striations associated with grinding wild grass grains (Aegilops ventricosa Tausch); h) smooth domed polish developed over the high and low micro topographies associated with the grinding of foxtail millet (Setaria italica (L.) P. Beauvois); i-l) spots of organic film, yellowish in color covering the crystal grains across the surface of archaeological GSTs; m,p) smooth domed micro polish identified on archaeological GSTs developing over the high and low surface micro topographies and associated with micro striations (m,n,p). q-w Starch granules identified on archaeological GSTs. (q) Type I (GST no. INV80); (r) Type I (GST no. INV146); (S) Type III (GST no. INV 28); (t) Type VI (GST no. INV.67); (u) Type VI (GST no. INV 10); (v) Type VI (GST no. INV146); (w) Type I (GST no. INV.71).

A total of 137 starch granules have been retrieved from the surfaces of the GSTs characterized by plant-related functional microscopic features. The optical and morphological properties of the starch granules support their attribution to morphotypes already documented in dental calculus from the Danube Gorges: type I assigned to caryopses of the tribe Triticeae (76) (Fig.4 Dd, Ee, Ff); type IV, assigned to the Fabaceae family (13) (Fig.4 Ii); type III assigned to the tribe Paniceae of the grass family Poaceae (16) (Fig.4 Gg); and type VI, assigned to berries of the family Cornaceae (32) (Fig.4Hh;Jj).

In sum, several hundreds of starch granules and phytoliths of grass grains of the Triticeae tribe have been identified in the analyzed dental calculus of the Mesolithic population in the Danube Gorges. In addition, residues and use-wear identified on GSTs from Late Mesolithic Vlasac show the existence of a plant food processing technology during this period aimed at preparing a coarse-grained flour through a combination of pounding and grinding gestures (Table 3 and Figs. 3, 9). Grit particles, often retrieved in the analyzed dental deposit (Table 2), further confirm the use of sandstone GSTs in food processing. The conclusion about the consumption of partially processed grains is corroborated by the presence of starch granules still lodged in their amyloplast on Mesolithic GSTs and dental calculus, as suggested in our previous study (Cristiani et al., 2016). Interestingly, A-Type granules in EN dental calculus are generally retrieved singularly and exhibit a damage pattern observed when producing fine-grained flour experimentally only through prolonged bidirectional grinding (Dietrich et al., 2019). The pattern of bidirectional grinding is not documented on the examined Late Mesolithic GST from Vlasac, suggesting the existence of two different grain processing modalities typical of respective Mesolithic and Neolithic cultural traditions.

Table 3. Late Mesolithic GSTs from the site of Vlasac. 


\begin{tabular}{|c|c|c|c|c|c|c|c|c|c|c|c|c|c|c|c|c|}
\hline 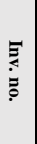 & 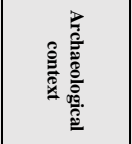 & 宽 & $\frac{\vec{g}}{\frac{\grave{g}}{\sigma}}$ & 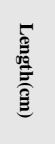 & 彥 & 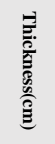 & 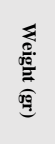 & 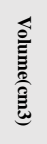 & 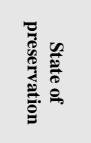 & $\underset{3}{3}$ & 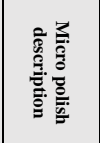 & 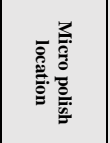 & 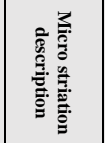 & 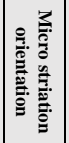 & 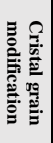 & $\begin{array}{l}\text { क्रे } \\
\text { है } \\
\text { है }\end{array}$ \\
\hline 10 & F KB $0,1 / \mathrm{III}$ & subangular & $\begin{array}{c}\text { Handstone/Gri } \\
\text { nder }\end{array}$ & 12.7 & 10.5 & 7.88 & 1542 & 645 & preserved & $\begin{array}{c}\text { light soil } \\
\text { concretion }\end{array}$ & $\begin{array}{c}\text { smooth and } \\
\text { domed }\end{array}$ & \begin{tabular}{|c|} 
high micro \\
topographies
\end{tabular} & \begin{tabular}{|c|} 
short \\
narrow \\
with a matt \\
bottom
\end{tabular} & $\begin{array}{l}\text { unidire } \\
\text { ctional }\end{array}$ & $\mathrm{Y}$ & mixed \\
\hline 13 & a1-VIII & round & $\begin{array}{c}\text { Handstone/Gri } \\
\text { nder }\end{array}$ & 11 & 8.16 & 5.68 & 680 & 287 & preserved & none & $\begin{array}{c}\text { smooth and } \\
\text { domed with } \\
\text { sporadic } \\
\text { pits } \\
\end{array}$ & $\begin{array}{c}\text { high and low } \\
\text { micro } \\
\text { topographies }\end{array}$ & NA & NA & $\mathrm{N}$ & longitudinal \\
\hline 23 & $\mathrm{BV} / \mathrm{C} / \mathrm{IV}-\mathrm{X}$ & subangular & Indeterminable & 11.7 & 8.79 & 8.76 & 823 & 367 & preserved & $\begin{array}{c}\text { light soil } \\
\text { concretion }\end{array}$ & $\begin{array}{c}\text { rough to } \\
\text { smooth } \\
\text { with domed } \\
\text { and flat } \\
\text { spots }\end{array}$ & $\begin{array}{c}\text { high and low } \\
\text { micro } \\
\text { topographies }\end{array}$ & NA & NA & $\mathrm{N}$ & longitudinal \\
\hline 28 & BIII-C/V & oval & Passive base & 13.3 & 11.8 & 7.18 & 1283 & 499 & fractured & none & smooth & $\mid \begin{array}{c}\text { high micro } \\
\text { topographies }\end{array}$ & NA & NA & $\mathrm{Y}$ & longitudinal \\
\hline 56 & A/II-XIII & round & Passive base & 15.9 & 14.8 & 7.7 & 1038 & 368 & preserved & $\begin{array}{c}\text { heavy } \\
\text { surface } \\
\text { concretion } \\
\text { on one } \\
\text { surface }\end{array}$ & $\begin{array}{c}\text { smooth } \\
\text { domed and } \\
\text { flat }\end{array}$ & $\begin{array}{c}\text { high micro } \\
\text { topographies }\end{array}$ & NA & NA & $\mathrm{Y}$ & Mixed \\
\hline 63 & $\mathrm{~b} / 17-\mathrm{XV}$ & round & $\begin{array}{c}\text { Handstone/Gri } \\
\text { nder }\end{array}$ & 8.4 & 6.6 & 4.47 & 403 & 141 & preserved & $\begin{array}{c}\text { light } \\
\text { surface } \\
\text { abrasion }\end{array}$ & $\begin{array}{l}\text { rough to } \\
\text { smooth } \\
\text { with } \\
\text { reticulated } \\
\text { and flat } \\
\text { spots }\end{array}$ & $\begin{array}{c}\text { high and low } \\
\text { micro } \\
\text { topographies }\end{array} \mid$ & NA & NA & $\mathrm{N}$ & longitudinal \\
\hline 65 & $\mathrm{C} / \mathrm{I}-\mathrm{VI}$ & round & Passsive base & 100 & 84.3 & 55.5 & 680 & 298 & broken & fractures & $\begin{array}{c}\text { smooth } \\
\text { domed and } \\
\text { reticulated }\end{array}$ & $\begin{array}{c}\text { high micro } \\
\text { topographies }\end{array}$ & $\begin{array}{c}\text { narrow } \\
\text { with a matt } \\
\text { bottom }\end{array}$ & mixed & $\mathrm{N}$ & longitudinal \\
\hline 66 & $\mathrm{C} / \mathrm{II} / \mathrm{V}$ & round & Indeterminable & 9.5 & 8.5 & 7.6 & 1170 & 437 & preserved & none & $\begin{array}{c}\text { smooth } \\
\text { domed and } \\
\text { cratered }\end{array}$ & $\begin{array}{l}\text { high and low } \\
\text { topographies }\end{array}$ & NA & NA & Y & mixed \\
\hline 67 & C/I-C/II-III & subangular & Passive base & 10.8 & 8.4 & 5.91 & 633 & 253 & broken & \begin{tabular}{|c|} 
light soil \\
concretion \\
and \\
surface \\
abrasion
\end{tabular} & $\begin{array}{c}\text { smooth and } \\
\text { reticulated }\end{array}$ & $\begin{array}{l}\text { high micro } \\
\text { topographies }\end{array}$ & $\begin{array}{c}\text { short and } \\
\text { deep with a } \\
\text { matt } \\
\text { bottom }\end{array}$ & $\begin{array}{l}\text { unidire } \\
\text { ctional }\end{array}$ & $\mathrm{N}$ & longitudinal \\
\hline 71 & $\mathrm{C} / \mathrm{I}-\mathrm{V}$ & round & $\begin{array}{c}\text { Handstone/Gri } \\
\text { nder }\end{array}$ & 72.1 & 57.9 & 45.9 & 309 & 119 & preserved & none & $\begin{array}{l}\text { smooth } \\
\text { domed to } \\
\text { flat }\end{array}$ & $\begin{array}{c}\text { high micro } \\
\text { topographies }\end{array}$ & $\begin{array}{l}\text { long and } \\
\text { shallow } \\
\text { with a } \\
\text { polished } \\
\text { bottom }\end{array}$ & mixed & $\mathrm{Y}$ & longitudinal \\
\hline 75 & $\mathrm{~b} / 18-\mathrm{V}$ & subangular & $\begin{array}{c}\text { Handstone/Gra } \\
\text { nder }\end{array}$ & 5.53 & 5.29 & 3.45 & 137 & 57 & broken & fractures & $\begin{array}{c}\text { smooth and } \\
\text { domed }\end{array}$ & $\begin{array}{c}\text { high and low } \\
\text { micro } \\
\text { topographies }\end{array}$ & $\begin{array}{c}\text { short } \\
\text { narrow } \\
\text { with a } \\
\text { polished } \\
\text { bottom }\end{array}$ & $\begin{array}{l}\text { unidire } \\
\text { ctional }\end{array}$ & $\mathrm{N}$ & longitudinal \\
\hline 80 & C/II-II/6 & ovate & Passive base & 9,85 & 8,35 & 3,72 & 547 & 225 & broken & none & $\begin{array}{l}\text { smooth } \\
\text { domed }\end{array}$ & $\begin{array}{c}\text { high micro } \\
\text { topographies }\end{array}$ & $\begin{array}{c}\text { short and } \\
\text { narrow } \\
\text { with a matt } \\
\text { bottom }\end{array}$ & $\begin{array}{l}\text { unidire } \\
\text { ctional }\end{array}$ & $\mathrm{Y}$ & longitudinal \\
\hline 134 & b/V3-XII & subangular & Indeterminable & 12.2 & 9.57 & 8.13 & 1433 & 565 & preserved & none & $\begin{array}{l}\text { smooth } \\
\text { domed }\end{array}$ & $\left|\begin{array}{c}\text { high and low } \\
\text { micro } \\
\text { topographies }\end{array}\right|$ & $\begin{array}{c}\text { short deep } \\
\text { with a matt } \\
\text { bottom }\end{array}$ & $\begin{array}{l}\text { unidire } \\
\text { ctional }\end{array}$ & $\mathrm{Y}$ & longitudinal \\
\hline 141 & $\mathrm{~B} / \mathrm{I} 0-8.9$ & round & $\begin{array}{c}\text { Handstone/Gri } \\
\text { nder }\end{array}$ & 10.8 & 9.92 & 9.22 & 370 & NA & preserved & $\begin{array}{c}\text { soil } \\
\text { concretion }\end{array}$ & $\begin{array}{c}\text { smooth } \\
\text { domed and } \\
\text { flat }\end{array}$ & $\begin{array}{c}\text { high micro } \\
\text { topographies }\end{array}$ & NA & NA & $\mathrm{Y}$ & longitudinal \\
\hline 146 & B/I-ISPOD 1.9 & round & $\begin{array}{c}\text { Handstone/Gri } \\
\text { nder }\end{array}$ & 6.65 & 5.7 & 4.66 & 275 & 106 & preserved & $\begin{array}{c}\text { light soil } \\
\text { concretion }\end{array}$ & $\begin{array}{c}\text { smooth } \\
\text { domed and } \\
\text { reticulated }\end{array}$ & $\begin{array}{l}\text { high micro } \\
\text { topographies }\end{array}$ & $\begin{array}{c}\text { short } \\
\text { narrow } \\
\text { with a matt } \\
\text { bottom }\end{array}$ & $\begin{array}{l}\text { unidire } \\
\text { ctional }\end{array}$ & $\mathrm{N}$ & longitudinal \\
\hline 162 & $\mathrm{~A} / 16-\mathrm{X}$ & round & $\begin{array}{c}\text { Handstione/Gri } \\
\text { nder }\end{array}$ & 10.6 & 9.3 & 7.52 & 1143 & 424 & preserved & none & $\begin{array}{l}\text { smooth } \\
\text { domed }\end{array}$ & $\begin{array}{c}\text { high and low } \\
\text { micro } \\
\text { topographies }\end{array}$ & $\begin{array}{c}\text { shirt } \\
\text { narrow } \\
\text { with a matt } \\
\text { bottom }\end{array}$ & $\begin{array}{l}\text { unidire } \\
\text { ctional }\end{array}$ & $\mathrm{Y}$ & longitudinal \\
\hline 167 & $\mathrm{a} / 15$-VII & round & Indeerminable & 8.94 & 8.82 & 5.65 & 611 & 241 & broken & $\begin{array}{c}\text { light } \\
\text { surface } \\
\text { abrasion }\end{array}$ & $\begin{array}{c}\text { rough } \\
\text { granular } \\
\text { and domed }\end{array}$ & $\begin{array}{l}\text { high and low } \\
\text { topographies }\end{array}$ & NA & NA & $\mathrm{Y}$ & orthogonal \\
\hline
\end{tabular}


For some time now, there has been a recognition of the importance of plant foods in forager diets, based on both archaeological and ethnographic evidence (Clarke, 1978; Lee and DeVore, 2017). Research on mineralized dental plaque has significantly advanced our awareness about ancient pre-agrarian food choices in Europe, Asia, and Africa, thanks to the dental plaque's potential to preserve plant micro-remains (Buckley et al., 2014; Cristiani et al., 2018, 2016; Cummings et al., 2018; Nava et al., 2021; Norström et al., 2019). However, in many archaeological case studies dating to early prehistory, preservation or recovery biases render plant food evidence invisible. In exceptional cases, good preservation has allowed for the remains of plant macro-remains to be found, such as wild cereals at the Epipaleolithic site of Ohalo II in Israel, dating to 23 kya (Nadel et al., 2012; Piperno et al., 2004), or parenchyma remains at the Gravettian site of Dolní Věstonice in the Czech Republic (Pryor et al., 2013). On the other hand, micro-remains of oat caryopses have been detected on GST found at the Gravettian site of Paglicci cave in Italy (Lippi et al., 2015). In a seminal synthesis about plant foods in the European Mesolithic, Zvelebil (1994) reviews macro- and micro-botanical, palynological, artefactual (antler hoes, mattocks, GST), and human osteological (dental size and presence of caries) evidence for the consumption of nuts and fruits by European Holocene foragers, arguing for a form of niche constructing in temperate woodlands by means of deliberate forest clearance in order "to increase the productivity of nut and fruit trees and shrubs, wetland plants, and possibly native grasses" (Zvelebil, 1994). The emphasis is on the existence of some form of husbandry of wild plant species, which did not necessarily lead to domestication. Furthermore, between 200 and 450 indigenous European edible plants (grass seeds, nuts, fruits, roots, tubers, pulses) are found concentrated in wetland (coastal, lacustrine, and riparian) habitats (Clarke, 1978). Despite preservation and recovery problems, hundreds of Mesolithic sites across Europe have yielded the remains of hazelnuts, acorns, water-chestnuts, and other remains (Zvelebil, 1994).

In this paper, two complementary lines of evidence that we examined provide the first unambiguous and direct support for the consumption and processing of Poaceae grains among other types of edible plants by the Early Holocene foragers in the Danube Gorges area. The chronological framework of the analyzed sample suggests that this interest in and familiarity with various species of wild grasses of the Triticeae tribe (namely grass grains of the genus Aegilops) dates back to at least $\sim 9500$ cal BC. Macrobotanical remains belonging to this genus have not been recovered at Mesolithic and Early Neolithic sites in the central Balkans (Cristiani et al., 2016: 10301). However, such absence in the archaeobotanical record could be the result of a host of taphonomic and recovery problems and should not be used to exclude the use of this genus during the Mesolithic (contra Cristiani et al. 2016: 4). Newly obtained evidence from the analysis of 61 individuals, which now also involves several EM individuals, lead us to suggest that Aegilops species were consumed in the region since the beginning of the Holocene. The mentioned difficulties associated with the recovery and preservation of botanical remains in local early prehistoric forager contexts along with some voids in the extant data regarding plant use by Mesolithic groups underlines the significance of our findings based on the application of 
466 We have previously argued that three Late Mesolithic individuals from the site of Vlasac dated 467 to the mid-seventh millennium cal BC (H53, 64.x11, and H232), as well as two presumed Early 468 Neolithic individuals from Lepenski Vir (8 and 20) exhibit starches consistent with 469 domesticated cereal species, such as Triticum monococcum L. (einkorn wheat), Triticum 470 dicoccum L. (emmer wheat), and/or Hordeum distichon L. (barley) (Cristiani et al., 2016). This 471 observation was based on the bimodal pattern of starch granules distribution, commonly 472 attributed to domestic species and absent in most of the wild species of the genus Aegilops 473 (Howard et al., 2011; Stoddard, 1999). This bimodal pattern is now further retrieved in two 474 other individuals from two different sites (H326 from Vlasac and HV16 from Hajdučka 475 Vodenica) dating to the Late Mesolithic and thus pre-dating the arrival of full-blown agriculture 476 in the region. However, burial 20 from Lepenski Vir, previously published as dating to the Early 477 Neolithic, has recently been directly AMS-dated to the Early Mesolithic (Table 1). This new 478 chronological attribution does not correspond with our expectations that domesticated grains 479 were introduced in the Danube Gorges only in the Late Mesolithic. At the face of the current 480 evidence, we explain this inconsistency in our results by arguing that the admittedly small 481 number of starch granules found in this archaeological specimen might have affected the 482 visibility of the potential variation in A-Type vs. B-Type population. Moreover, a large 483 variability of starch granule distributions among different species of the Triticeae tribe has been 484 acknowledged in the literature (Henry and Piperno, 2008; Yang and Perry, 2013) and supported 485 by our experimental reference (Fig. 9). Furthermore, fluctuations in environmental and growing 486 conditions have also been recognised as relevant factors affecting starch granule size 487 distribution (Stoddard, 1999; Stoddard and Sarker, 2000). 
Figu re 9. Starc $\mathrm{h}$

gran ule lengt $\mathrm{h}$ in mod ern wild and dom estic cerea 1 speci es. a) Distr ibuti on of starc $\mathrm{h}$ gran ule lengt $h$ in wild speci es;

b) distri butio $\mathrm{n}$ of dom estic ated speci es; c) Violi $\mathrm{n}$ plot of

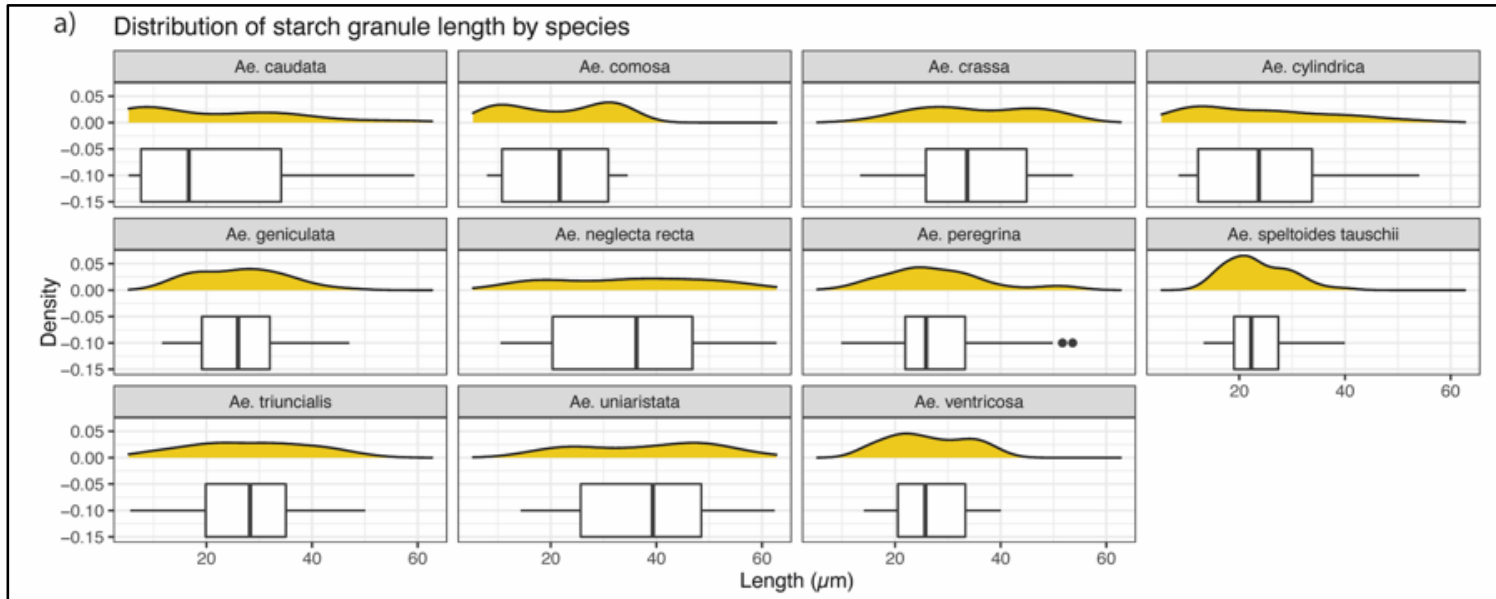

b) Distribution of starch granules length by species
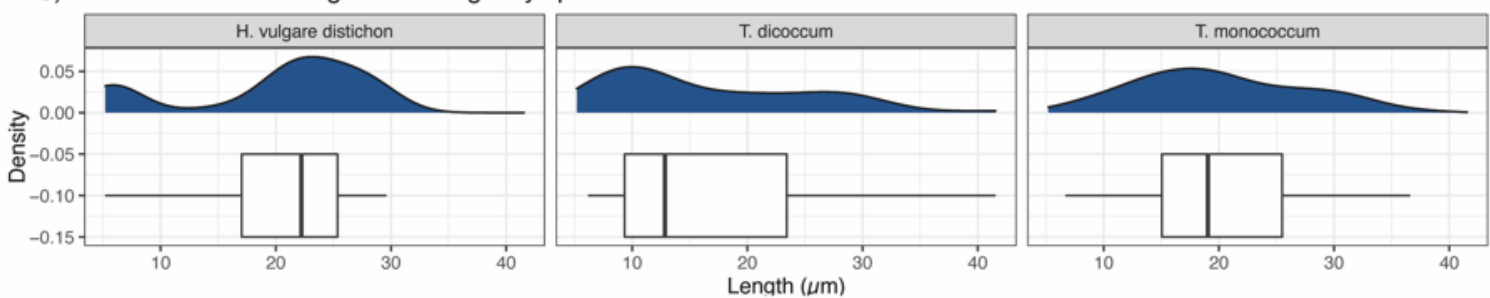

c) Length of starch granules
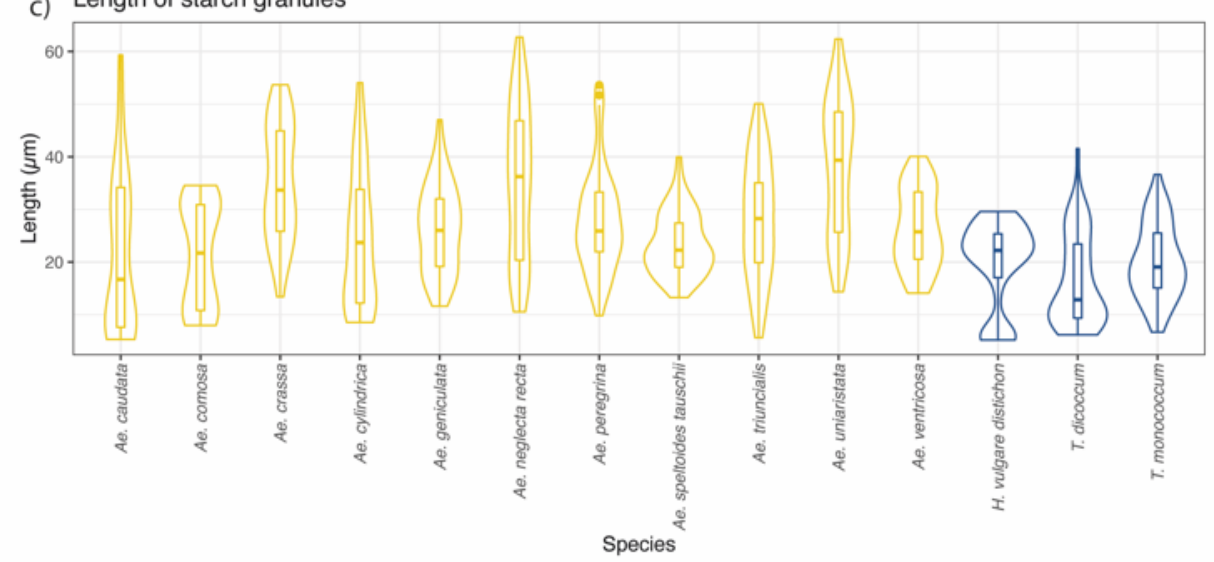

d) Variation in length of starch granules
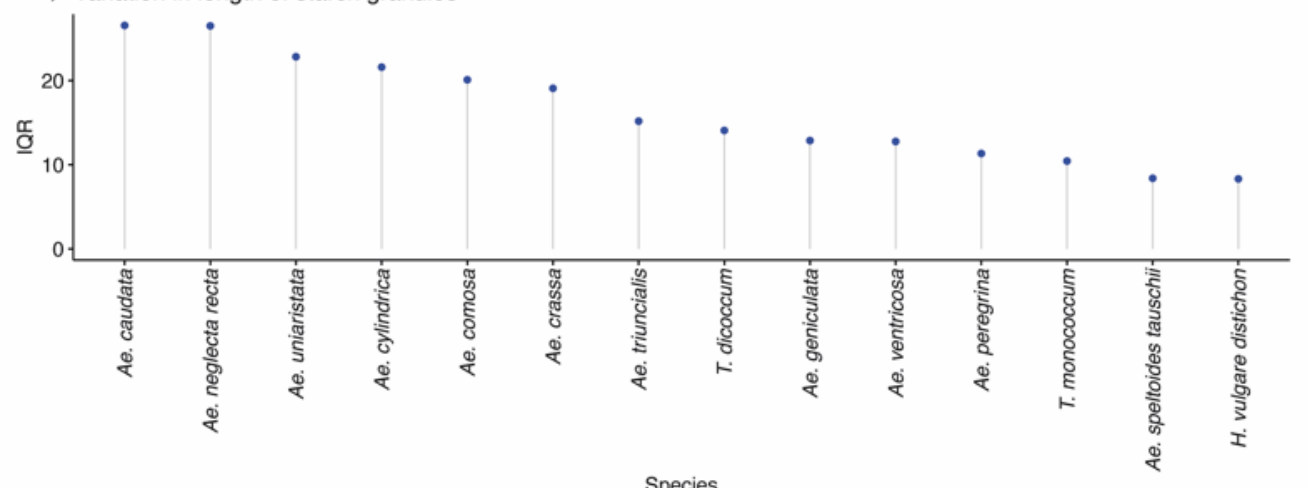

comparing the length of starch granules in wild and domesticated species; d) Interquartile Range (IQR) ranges of wild and domestic species. IQR corresponds to the difference in the medians of the lower and upper half of the data.

Figure 9-source data 1. Starch granule length in modern wild and domestic cereal species. 
In addition to starch granules, other micro-remains, such as phytoliths and burnt debris, were recovered in the dental calculi of the analyzed Mesolithic population (Fig. 5L,M,Y). The paucity of archaeological phytoliths calls for caution when interpreting their dietary origin. Yet, the presence of few dendritic phytoliths in local forager dental calculus is likely related to plant consumption, as such micro-remains have experimentally been associated with mechanical destruction of husks and culms of Pooids by grinding (Portillo and Albert, 2014). In the investigated population, phytoliths could potentially provide means of understanding the use of plants as kindling and exposure to potential respiratory irritants generated during daily life activities, but their pathways are too many to narrow them down, and further work is required to better understand the origin of burnt material in dental calculus (Radini et al., 2019, 2017; Scott and Damblon, 2010). The retrieval of phytoliths from herbaceous plants that appear burnt could suggest that plant materials, potentially harvested, were used in a diverse range of activities, including kindling and roofing. Phytoliths of such plants might have also been naturally present in the environment, water, and soil (Norström et al., 2019). Such burnt debris may have reached the mouth by accidental ingestion through food and/or breathing. Other micro-debris, such as nettle and wood fibers, might have also been linked to textile. Pathways to wood inclusion in calculus vary from the use of a toothpick to crafting activities (Radini et al., 2016) and the production and maintenance of weapons, such as arrowheads.

For the moment, it remains unclear to what extent plant foods, and species of the Poaceae family, contributed to the diet of the Danube Gorges foragers, and it is equally difficult to be more specific about the range of activities involved in their acquisition prior to processing and consumption - from sporadic collecting of wild grasses to forest clearances, or some form of indigenous system of plant management. Yet, it seems clear from our data that this specific subsistence practice was passed over generations in this regional context up to the first contacts of these foragers with Neolithic, farming groups in the second half of the seventh millennium BC. Previously, we suggested that some sort of exchange between Late Mesolithic foragers and first Neolithic groups in the southern Balkans might have allowed for the introduction of the domesticated species of Triticeae in the Danube Gorges area $\sim 6500$ cal BC (Cristiani et al., 2016). Now, our extended study seems to suggest that this introduction of domesticated cereals, i.e. more productive cereal strains from Southwestern Asia, was preceded by several millennia of collecting and consumption of native grass grains. Adoption of previously unknown plant foods is often facilitated by those local foods that in shape and taste resemble the new arrivals (Livarda, 2011). Incipient management practices on certain wild plant taxa have been documented among non-agricultural societies for environmental and/or cultural reasons, for protecting or promoting the relative abundance of a species, or for reducing the energy involved

Another recent study of dental calculus from the Danube Gorges area has reached a conclusion that domesticated cereals started to be used in this region only with the start of the Neolithic (Jovanović et al., 2021). In the same study, the individuals dated to the Early Mesolithic exhibit a high occurrence of starch granules, which we have shown to be compatible with a variety of wild species of the Triticeae tribe (e.g., genus Aegilops). Jovanović et al. (2021:10) disregard the 
evidence of Aegilops consumption during the Early Mesolithic as an "implausible pattern". However, our results, based on the combination of a robust sample of analyzed individuals, GSTs, and experimental data are in opposition to the conclusions of the mentioned study.

Most of prehistoric forager groups might have had regular access to plant nutrients and some sort of dependency on specific plants (Fuller et al., 2011). Accordingly, in our analysis of dental calculus and GSTs, we have shown that besides wild grasses, local foragers consumed oat, legumes, minor millet species of the genus Echinochloa and/or Setaria known as "forgotten millets" (cfr Madella et al., 2016; Weber and Fuller, 2008), acorns, and Cornelian cherries (Fig. 4; Tables 1,2). Even if secure identification to species or genus level was not possible in every case (cfr. Soto et al., 2019), the morphological characteristics of starch granules systematically encountered in our archaeological samples, and the data available for the analysis of material culture, clearly show a contribution to the diet from these plant taxa.

Several starch granules of the tribe Aveneae have been identified in dental calculus, especially during the Late Mesolithic. Very abundant in temperate ecosystems, oat caryopses have been processed as foodstuff already during the Upper Palaeolithic at Paglicci Cave, in the south of Italy (Lippi et al., 2015). They have also been documented in the dental calculus of the aforementioned Late Mesolithic individual from Vlakno Cave in the Eastern Adriatic region (Cristiani et al., 2018). Overall, starch granules of this tribe were remarkably well preserved in our dental calculus samples and large aggregates characterizing Aveneae were abundant. Interestingly, starches of this tribe recorded on archaeological GSTs, and associated with the production of flour, consist of abundant single sparse polyhedral granules (Lippi et al., 2015). In our case study, exceptionally well-preserved aggregates of Aveneae have been identified in dental calculus only. The concentration of semi-open aggregates (Figs. 4G, 5K,U) sustains the hypothesis of a coarse processing of the seeds during the Mesolithic, already suggested for other grass grain taxa.

Small starch granules from grasses of the Poaceae family have been attributed to the Andropogoneae and Paniceae tribes (Fig. 5B,C) (Madella et al., 2016). Our results confirm previous conclusions about the use of grasses of the tribe Paniceae by the Late Mesolithic foragers (Cristiani et al., 2016), while extending the consumption of this general types of millets to Early Mesolithic foragers too. However, no evidence of this food has been ascertained on the basis of stable isotope analysis (Borić et al., 2004). This pattern could mean that their consumption was not predominant in dietary practices of these Mesolithic foragers. We stress that a great variety of species of $\mathrm{C}_{4}$ plants belonging of the tribe Paniceae and the tribe Andropogoneae (e.g., species of plants of the genera Setaria Beauv. and Echinochloa P. Beauv.) grow well nearby water environments and slow-flowing waters, and it is very likely that a mixture of species from such genera might have contributed to the Mesolithic diet. Furthermore, they often grow in association with each other. The presence of Paniceae and the Andropogoneae tribes, combined with the evidence of several feather barbule fragments from aquatic birds, clearly point to a familiarity with resources from riverine environments other than fish. 
Species of the family Fabaceae are well represented in the Early Mesolithic and Late Mesolithic individuals from the Danube Gorges area. While a secure identification to species or genus was not possible in our samples, we know that wild pulses (Lens sp. Mill.) and bitter vetch (Vicia ervilia (L.) Willd.) were used as foodstuffs for the Mesolithic inhabitants of Franchthi Cave (Asouti et al., 2018; Van Andel et al., 1987). Further evidence for a pre-Neolithic consumption of the species of the tribe Fabeae comes from Uzzo Cave, Italy, where wild legumes (Lathyrus sp. L., Pisum sp. L.) are well represented along with other arboreal fruits (Arbutus unedo L.), acorns (Quercus sp. L.), and wild grapes (Vitis vinifera subsp. sylvestris L.) (Costantini, 1989), as well as from the site of Barma Abeurador in southern France (Vaquer et al., 1986). In addition to the evidence from dental calculus, indirect evidence for the consumption of species of the family Fabaceae has also been retrieved from one GST (Fig. 4Ii).

Species of the Fagaceae family (cfr. Quercus ilex L., Quercus sp. L.) were also a significant food resource for the Danube Gorges foragers (Fig. 5A). Fragments of acorns were found at several Mesolithic sites across Europe (Holden et al., 1995; Kubiak-Martens, 1999) and in the investigated region (Mason, 1995).

Evidence for the consumption of Cornelian cherries ( $C$. mas L.) has been retrieved in dental calculus belonging to Late Mesolithic and Mesolithic/Neolithic individuals from Vlasac (Fig. $5 \mathrm{~N}-\mathrm{P}$ ) and also on eight GSTs from the same site. The results based on the analyses of GSTs not only corroborate the evidence for the use of these fruits derived from the calculus analysis, but also support the role of such plants in Mesolithic daily life. Cornelian cherries are the most recurrent macro-remains at Vlasac and are documented across Europe as a Mesolithic source of food and medicine (Divišová and Š́́da, 2015; Filipović et al., 2010). Ethnographically, various fruits commonly referred to as "cherries" and/or "berries" are particularly well documented among Native American groups (Siegfried, 1994; Zarrillo and Kooyman, 2006). Throughout much of North America several species of the Cornaceae and Rosaceae plant families were processed using unmodified pounding stone tools to add to pemmican or to dry as cake. Interestingly, Woodland Cree people used to mix berries and cherries with fish eggs (Siegfried, 1994) and meat (Lowie, 1922).

We conclude that the long-lasting interactions with edible grains (but also wild pulses), documented in the Balkans since the end of the Pleistocene might have allowed enough time for specific eating habits, tastes, and "cultural valuation" (Hastorf and Foxhall, 2017) to develop. Such a shared knowledge about specific plant resources effectively predates the introduction of agriculture in Europe, and might have eventually eased the introduction of domesticated species starting from the second half of the seventh millennium BC. Our results call for more systematic and interdisciplinary research in order to reconstruct plant food traditions and cultural tastes before the introduction of agriculture.

\section{Materials and Methods}

The examined collection of the teeth previously studied for strontium isotopes (Borić and Price, 2013) from five sites in the Danube Gorges area and the site of Gârleşti from the region of 
Oltenia in Romania and additionally collected teeth from the sites of the Velesnica and the

673 2006-2009 excavations at Vlasac contained a total of 155 specimens. Of these, a total of 60

674

675

676

677

678

679

680

681

682

683

684

685

686

687

688

689

690

691

692

693

694

695

696

697

698

699

700

701

702

703

704

705

706

707

708

709

710

711

712

713

714

715 individuals had sufficiently preserved calculi for further analyses (Table 1): 13 individuals date to the Early Mesolithic (EM), 29 to the Late Mesolithic (LM), 9 to the Mesolithic-Neolithic transition phase $(\mathrm{M} / \mathrm{N})$, and 8 to the Early Neolithic $(\mathrm{EN})$. In addition, two later period burials were also included in the analysis as a methodological comparison (Table 1). In order to corroborate data obtained through dental calculus analysis, we also analyzed 101 sandstone GSTs of the 131 implements found at the site of Vlasac during the 1970-71 excavations and chronologically attributed to the Late Mesolithic (Borić et al., 2014; Srejović and Letica, 1978). While GSTs are well documented during the Mesolithic-Neolithic transition at the site of Lepenski Vir (Antonović, 2006), earlier evidence for their use is available only from the site of Vlasac. This site yielded the richest Mesolithic assemblage of non-flaked stone tools recovered so far in the region (Antonović et al., 2006; Borić et al., 2014; Srejović and Letica, 1978). GSTs underwent a functional study aimed at verifying their function and potential involvement in plant food processing (Table 3 and Fig. 3).

\section{Dental calculus - sampling, extraction, decontamination and examination procedures}

All the sampling was conducted under the stereoscope, as can be seen in Fig. 2 (for more details see below), and following strict protocols systematized by Sabil and Fellow Yates (Sabin and Fellow Yates, 2020) with some variation (disposable blades were changed after each sample extraction). Deposits of dental calculus were judiciously left on the teeth for future research. Whenever possible, sampled dental calculus was further subdivided for metagenomic analysis aimed at reconstructing aDNA of oral bacteria (Ottoni et al., 2021).

Decontamination and the extraction procedures for micro-debris were conducted in dedicated clean spaces not connected to modern botanical work and under strict environmental monitoring of the DANTE laboratory of Sapienza University of Rome (IT), the BioArch laboratory at University of York (UK), and the aDNA facility of the University of Vienna (Austria). In all of these facilities, strict contamination rules were followed. Cleaning is carried out daily and no food is allowed in order to prevent any type of modern contamination. Bench space surfaces were cleaned prior to the analysis of each sample, using soap and ethanol, followed by covering of the surfaces by aluminium foil, and using of clean starch-free nitrile gloves at all times. Calculus cleaning was carried out under the stereomicroscope, on a Petri dish previously washed and immersed in hot ultrapure water, with magnifications up to 100x. The removal of the mineralized soil adhering on the surface of the calculus was meticulously carried out using sterile tweezers to hold the sample and a fine acupuncture needle to gently scrape off the soil attached to the external layer of the mineralized plaque. The procedure was performed using drops of $0.05 \mathrm{M}$ Hydrochloric $(\mathrm{HCl})$ acid to dissolve the mineralized flecks of soil and ultrapure water to block the demineralization, as well as to wash and remove the contaminants. Once the calculus surface was cleaned, the contaminated soil was checked for possible cross contamination and the clean samples were washed in ultrapure water up to three times in order to remove any trace of sediment. The clean calculus was then dissolved in a solution of $0.5 \mathrm{M}$ $\mathrm{HCl}$ and subsequently mounted on slides using a solution of 50:50 glycerol and ultrapure water. Furthermore, control samples from the clean working tables and dust-traps were collected and 
analyzed for comparative purposes in order to prevent any type of modern contamination in these laboratories - this is a practice routinely done in our laboratories, even at times where no archaeological analysis occur, to allow a better understanding of the flow of contaminations through seasons. Our results based on this procedure show that synthetic and plant fibers and hairs, fungal spores and hyphae, palm and conifer pollens, insects' debris; maize starch granules were detected twice while unidentified small starch granules were very rare; phytoliths and starch granules belonging to species of the Triticeae tribe were never recovered (Fig. 10). We did not retrieve any debris morphologically similar to any of the remains in the environmental control samples. Furthermore, starch granules amounted to a neglectable fraction of the laboratory "dust" - suggesting it is extremely unlikely that an event of contamination of starch granules would occur in the lab, where no other remains from dust, way more common, were not found.

The examination of micro-debris embedded in the calculus matrix was performed at Sapienza University of Rome and at the University of York using a Zeiss Imager2 cross and an Olympus polarized microscope with magnifications ranging from $100 \mathrm{X}$ to $630 \mathrm{X}$. A modern reference collection of 300 plants native to the Balkans, the Mediterranean region, and Europe was used as a comparison, along with published literature, for the identification of archaeological starch granules. The experimental reference collection also included species documented in the local archaeological record (Filipović et al., 2010; Marinova et al., 2013).

\section{Ground Stone Tools functional analysis}

GSTs were sampled and analyzed at the Archaeological Collection of the University of Belgrade. Strict protocols were followed for controlling modern contamination during the residue sampling and functional analysis of GSTs: bench surfaces where the work was conducted were cleaned before the analysis of each tool using ethanol, hot water, and covered by aluminium foil; starch-free gloves were used while handling the GSTs; dust samples from the storage boxes and the working tables were collected and analyzed for comparative purposes; use-wear and residue analyses were performed on the surfaces not affected by severe postdepositional modifications and free from concretions. Furthermore, starch granules were considered reliable only when in combination with use wear traces associated with plant processing.

Functional study involved the analysis of use-wear traces on the GST surfaces at low magnification $(0.75 \mathrm{x}-168 \mathrm{x})$ using a Zeiss Discovery V20 stereomicroscope and at high magnification (200x-500x) with a Zeiss AxioScope metallographic reflected light microscope(Cristiani and Zupancich, 2020; Dubreuil et al., 2015). At low magnification, GSTs were analyzed using a Zeiss Discovery V20 Stereomicroscope, which allowed us to assess the state of preservation of the materials and identify the residues still adhering to the surfaces. Appearance, morphological features, and spatial patterns of macro-residue distribution were considered (Langejans, 2010). Casts of the used areas were taken by means of a high-resolution polyvinylsiloxane (Provil Novo Light Fast Set), and later analyzed at high magnification (up to 
500x) at the DANTE Laboratory at the Sapienza University of Rome. Micro-polish, abrasions, 761 and micro striations across the tools' surfaces were identified using a Zeiss AxioScope 762 metallographic microscope, and described following relevant parameters available in literature 763 (Adams et al., 2006; Dubreuil et al., 2015; Hamon and Plisson, 2009).

Micro-residues were sampled before surface casts. Ultrapure water was placed on the crevices 766 of surface and left for one minute on the artefact in order to soften the residues, then pipetted out 767 and stored in a sterile tube. Once in laboratory, the samples were centrifuged and the natant 768 mounted on microscope slides using a 50\% solution of purified water and glycerol. Slides were subsequently analyzed in transmitted light using Zeiss Imager2 microscope (630x) and crosspolarizing filters. For archaeological residues, appearance, morphological features, and spatial patterns of distribution were considered (Cristiani and Zupancich, 2020).

An experimental reference collection of used GSTs and starch granules housed at the DANTE laboratory was consulted along with relevant literature and scientific databases. High-resolution images of the identified use-wear and residue were taken at 630x using a Zeiss Axiocam 305 high definition color camera. Risk of modern contamination from the storage and sampling environment was minimized following a strict cleaning procedure before and during the sampling/analysis. 

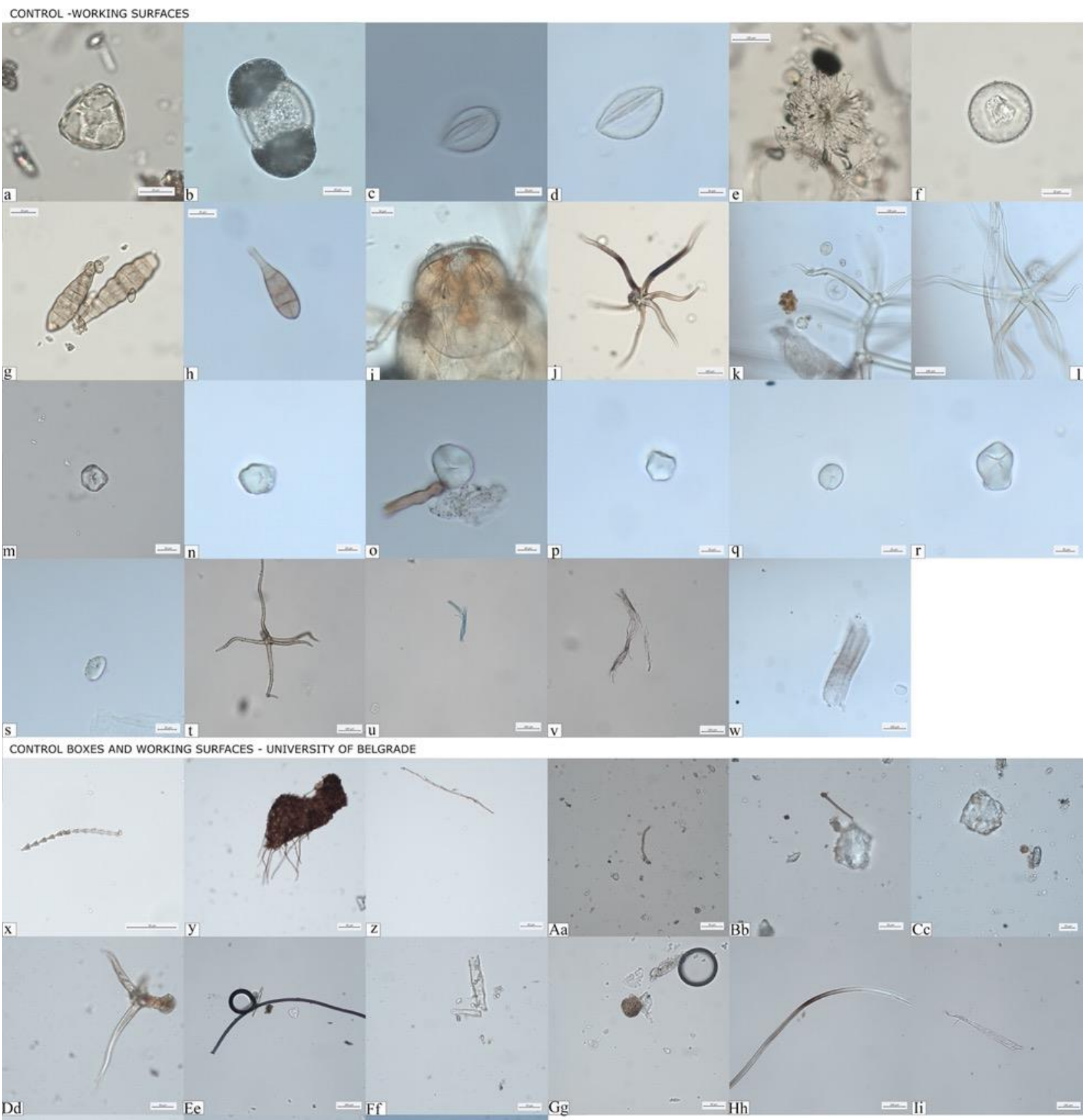

Figure 10. Controls for contamination. (a-w) Evidence of pollutants retrieved from clean working surfaces and dust traps located in different areas of the DANTE Laboratory at Sapienza University of Rome; (x-Ll) Dust recorded in storage boxes where groundstone tools were stored at the Faculty of Philosophy, University of Belgrade.

Testing morphological differences in experimental starch granules from Aegilops, Hordeum, and Triticum species 
Methodologically, we were able to characterize the morphological variability of starch granules in ancient plant species consumed in the investigated area, hence complementing our previous work and its implications (Cristiani et al., 2016). Differences in the starch granules assigned of the tribe Triticeae in the analyzed individuals were identified on the basis of (l) the specific morphology, dimensions, and appearance of type A and B granules; and (2) the proportion between A-Type and B granules. In particular, during the EM A-Type granules preserved in calculi are very large and round in shape with deep lamellae visible only in the granules' mesial part. Additionally, B-Type granules with different sizes and shape have been recorded in all of the EM individuals and most of Late Mesolithic (LM) individuals (Fig. 4). This feature is absent in the Early Neolithic (EN) individuals analyzed in this work, displaying only identical small round B-Type granules, while A-Type granules are large, round to oval/lenticular, with lamellae less pronounced in the mesial part of the grains and well visible craters on their surfaces (Fig. $4 \mathrm{Y})$. We could not match these differences in our experimental record, which includes various Aegilops species as well as wild species within the genera Hordeum, Elymus L., Agropyron Gaertn., Dasypyron L. growing locally, and in the literature (see Henry et al. 2010). The abovementioned features have consistently been assigned to modern domestic Triticeae species (Triticum spp. and Hordeum spp.) (Cristiani et al., 2016; Piperno et al., 2004; Yang and Perry, 2013). Given the high variability recorded in the dimensions and distribution of starch granules within the modern, locally available, species of the genus Aegilops (Fig.6A-J), further statistical work was carried out in order to interpret starch granules assigned to the tribe Triticeae in Mesolithic/Neolithic transitional contexts.

Caryopses from 11 Aegilops species (A. triuncialis, A. comosa, A. crassa, A. cylindrica, A. geniculata, A. neglecta, A. speltoides tauschii, A. peregrina; A. triuncialis, A. uniaristata, A. ventricosa), 1 Hordeum species (Hordeum vulgare distichon), and 2 Triticum species (Triticum monococcum; $T$. dicoccum) grown in the central Balkans were collected. All plant material was grounded using pestle and mortar. Starch powder $(0.5 \mathrm{mg})$ was resuspended in $100 \mu \mathrm{L}$ of sterile distilled water and vortexed for 5 minutes. After that, the sample was observed by an optic transmitted light microscopy (Fig. 6). Fifty starch granules were randomly selected (for size and shape), counted, and their length measured. Minimum and maximum lengths, mean, and median values with relative standard deviations and Interquartile ranges (IQR) were reported for each species in Table 4. Length distribution and variation of modern starches were reported in Fig. 9. Finally, length distribution of the starches from each species was compared with the other species to investigate the existence of significant differences. This statistical analysis was carried out through a Pairwise Wilcoxon test (Table 5). Results were considered significant for p-values $<0.05(<0.05 ; *<0.01 ; * * *<0.001)$ and not significant (n.s.) for measurements $>0.05$.

Triticeae starches are known to possess a bimodal distribution, made up of small (B-type) and large (A-type) granules (Fig. 6). In the analyzed Triticum and Hordeum genera, B-type grains are more abundant than A-type, except for $H$. secalinum Schreb., which does not exhibit the large granules. Differently, in Aegilops genus, the size distribution of starches is characterized by two different trends. The first one, evidenced in A. caudata L., A. cylindrica Host, A. comosa Sm., and A. speltoides tauschii Coss., appears very similar to that of Triticum and Hordeum samples, although B-type grains are less abundant than their counterparts in wheat and barley. 
832 On the other hand, the second cluster (A. crassa Boiss. ex Hohen., A. geniculata Roth, A. 833 neglecta Req. ex Bertol., A. speltoides tauschii Tausch, A. triuncialis L., A. uniaristata Vis., and 834 A. ventricosa Tausch) exhibits larger starches, determining a significant shift of the mean size 835 towards intermediate lengths. In general, the present experimental analysis revealed that 836 Aegilops sp. starch granules show a larger size distribution than Hordeum sp. and Triticum sp. 837 (Figs. 6,9). This evidence is also supported by the Pairwise Wilcoxon test, which highlights that 838 Aegilops spp. starch measurements are significantly different from those obtained for Hordeum 839 sp. and Triticum sp. counts (Table 4). 
841 Table 4. Summary statistics of the length of wild grass grains and domestic cereal starch

842 granules.

Table 4-source data 1. Summary statistics of the length of wild grass grains and domestic cereal starch granules.

\begin{tabular}{||l||c||c||c||c||c|c||c||}
\hline \multicolumn{1}{|c|}{ Species } & Min. & Max. & Mean & Median & StDev. & Range & IQR \\
\hline \hline A. caudata & 5.29 & 59.3 & 21.6 & 16.7 & 15.17 & $5.29-59.33$ & 26.55 \\
\hline \hline A. comosa & 7.95 & 34.5 & 21.5 & 21.7 & 9.78 & $7.95-34.54$ & 20.09 \\
\hline \hline A. crassa & 13.38 & 53.7 & 35.3 & 33.7 & 11.09 & $13.38-53.69$ & 19.08 \\
\hline \hline A. cylindrica & 8.52 & 54.0 & 24.2 & 23.7 & 13.07 & $8.52-54.05$ & 21.6 \\
\hline A. geniculata & 11.61 & 47.0 & 26.3 & 26.0 & 8.39 & $11.61-47.03$ & 12.87 \\
\hline \hline A. neglecta recta & 10.54 & 62.7 & 35.0 & 36.2 & 14.46 & $10.54-62.71$ & 26.5 \\
\hline A. peregrina & 9.84 & 53.6 & 27.8 & 25.9 & 9.89 & $9.84-53.62$ & 11.34 \\
\hline \hline A. speltoides tauschii & 13.25 & 40.0 & 23.5 & 22.2 & 5.93 & $13.25-39.97$ & 8.39 \\
\hline \hline A. triuncialis & 5.60 & 50.1 & 28.2 & 28.2 & 11.24 & $5.60-50.06$ & 15.18 \\
\hline \hline A. uniaristata & 14.35 & 62.4 & 38.2 & 39.3 & 12.87 & $14.35-62.38$ & 22.83 \\
\hline \hline A. ventricosa & 14.10 & 40.0 & 26.3 & 25.7 & 7.44 & $14.10-40.04$ & 12.77 \\
\hline \hline H. vulgare distichon & 5.19 & 29.6 & 19.7 & 22.2 & 8.12 & $5.19-29.59$ & 8.32 \\
\hline \hline T. dicoccum & 6.17 & 41.5 & 16.5 & 12.8 & 8.66 & $6.17-41.55$ & 14.07 \\
\hline \hline T. monococcum & 6.68 & 36.6 & 20.1 & 19.1 & 7.11 & $6.68-36.61$ & 10.44 \\
\hline \hline
\end{tabular}


Table 5. Pairwise Wilcoxon test performed on the length distribution of modern starches from Aegilops, Hordeum, and Triticum species ( $p$-value: not significant/n.s. $>0.05 ; *<0.05 ; * *<0.01$; $* * *<0.001)$.

Table 5-source data 1. Length of modern starch granules of Aegilops, Hordeum, and Triticum species

\begin{tabular}{|c|c|c|c|c|c|c|c|c|c|c|c|c|}
\hline $\begin{array}{c}\text { A. } \\
\text { caudat } \\
\text { a }\end{array}$ & $\begin{array}{c}A . \\
\text { comos } \\
a\end{array}$ & $\begin{array}{c}\text { A. } \\
\text { crass } \\
a\end{array}$ & $\begin{array}{c}\text { A. } \\
\text { cylindri } \\
\text { ca }\end{array}$ & $\begin{array}{c}\text { A. } \\
\text { genicul } \\
\text { ata }\end{array}$ & $\begin{array}{c}A . \\
\text { neglecta } \\
\text { recta }\end{array}$ & $\begin{array}{c}A . \\
\text { peregr } \\
i-\end{array}$ & $\begin{array}{l}\text { A. speltoides } \\
\text { tauschii }\end{array}$ & $\begin{array}{c}\text { A. } \\
\text { triuncia } \\
\text { lis }\end{array}$ & $\begin{array}{c}\text { A. } \\
\text { uniarist } \\
\text { ata }\end{array}$ & $\begin{array}{c}A . \\
\text { ventrico } \\
\text { sa }\end{array}$ & $\begin{array}{l}\text { H. vulgare } \\
\text { distichon }\end{array}$ & $\begin{array}{c}T . \\
\text { dicocc } \\
\text { um }\end{array}$ \\
\hline
\end{tabular}

\begin{tabular}{|c|c|c|c|c|c|c|c|c|}
\hline A. comosa & $\mathrm{ns}$ & - & - & - & - & - & - & - \\
\hline A. crassa & $* * *$ & $* * *$ & - & - & - & - & - & - \\
\hline $\begin{array}{l}\text { A. } \\
\text { cylindrica }\end{array}$ & ns & ns & $* * *$ & - & - & - & - & - \\
\hline $\begin{array}{l}\text { A. } \\
\text { geniculata }\end{array}$ & ns & $*$ & $* * *$ & $\mathrm{~ns}$ & - & - & - & - \\
\hline $\begin{array}{l}\text { A. neglecta } \\
\text { recta }\end{array}$ & $* * *$ & $* * *$ & ns & $* * *$ & $* * *$ & - & - & - \\
\hline A. peregri- & $*$ & $* *$ & $* *$ & $\mathrm{~ns}$ & ns & $* *$ & - & - \\
\hline $\begin{array}{l}\text { A. speltoides } \\
\text { tauschii }\end{array}$ & $\mathrm{ns}$ & ns & $* * *$ & $\mathrm{~ns}$ & ns & $* * *$ & $*$ & - \\
\hline $\begin{array}{l}\text { A. } \\
\text { triuncialis }\end{array}$ & $*$ & $* *$ & $* *$ & $\mathrm{~ns}$ & ns & $*$ & ns & $*$ \\
\hline $\begin{array}{l}\text { A. } \\
\text { uniaristata }\end{array}$ & $* * *$ & $* * *$ & $\mathrm{~ns}$ & $* * *$ & $* * *$ & $\mathrm{~ns}$ & $* * *$ & $* * *$ \\
\hline $\begin{array}{l}\text { A. } \\
\text { ventricosa }\end{array}$ & $\mathrm{ns}$ & * & $* * *$ & $\mathrm{~ns}$ & $\mathrm{~ns}$ & $* * *$ & $\mathrm{~ns}$ & ns \\
\hline $\begin{array}{l}\text { H. vulgare } \\
\text { distichon }\end{array}$ & $\mathrm{ns}$ & ns & $* * *$ & $\mathrm{~ns}$ & $* * *$ & $* * *$ & $* * *$ & $*$ \\
\hline $\begin{array}{l}\text { T. dicoccum } \\
T . \\
\text { monococcu }\end{array}$ & $\mathrm{ns}$ & $*$ & $* * *$ & $* *$ & $* * *$ & $* * *$ & $* * *$ & $* * *$ \\
\hline & $\mathrm{ns}$ & ns & $* * *$ & ns & $* * *$ & $* * *$ & $* * *$ & $*$ \\
\hline
\end{tabular}

\section{Acknowledgments}

878 The authors wish to thank the late Živko Mikić (University of Belgrade), the late Borislav Jovanović (Serbian Academy of Sciences and Arts), Duško Šljivar (National Museum in Belgrade), and Jelena Rankov (National Museum, Belgrade) for permissions to sample the osteological collections from the Danube Gorges. Funding: The research leading to these results has received funding from the European Research Council (ERC) under the Horizon 2020 Framework Program (Starting Grant Project HIDDEN FOODS grant agreement no. 639286 to EC), the National Science Foundation Grant BCS-0235465 to TDP and DB, the NOMIS Foundation grant to DB. Funding for excavations at Vlasac in 2006-2009 was provided by the grants from the British Academy (SG-42170 and LRG-45589) and the McDonald Institute for Archaeological Research, University of Cambridge to DB. This research was also in part funded by the Wellcome Trust (grant number 209869_Z_17_Z to AR). For the purpose of open access, the authors have applied a CC BY public copyright licence to any Author Accepted Manuscript version arising from this submission. For the purpose of open access, the author has applied a CC BY public copyright license to any Author Accepted Manuscript version arising from this submission. Competing interests: The authors declare that they have no competing interests. Data and materials availability: All data needed to evaluate the conclusions in the paper are present in the paper and in the surce data. Additional data related to this paper may be requested from the authors. 


\section{References}

Adams JL, Delgado S, Dubreuil L, Hamon C, Plisson H, Risch R. 2006. Functional analysis of macro-lithic artefacts: A focus on working surfaces In: Sternke F, Eigeland L, Costa L-J, editors. BAR International Series. Presented at the Non-Flint Raw Material Use in Prehistory. Archaeopress.

Antonović D. 2006. Stone tools from Lepenski Vir. Belgrade: Institute of Archaeology.

Asouti E, Ntinou M, Kabukcu C. 2018. The impact of environmental change on Palaeolithic and Mesolithic plant use and the transition to agriculture at Franchthi Cave, Greece. PLoS One 13: 0207805.

Barton H, Mutri G, Hill E, Farr L, Barker G. 2018. Use of grass seed resources c.31 ka by modern humans at the Haua Fteah cave, northeast Libya. Journal of Archaeological Science 99:99-111.

Blumenthal C, Bekes F, Gras PW, Barlow EWR, Wrigley CW. 1995. Identification of wheat genotypes tolerant to the effects of heat stress on grain quality. Cereal Chem.

Blumenthal C, Wrigley CW, Batey IL, Barlow EWR. 1994. The heat-shock response relevant to molecular and structural changes in wheat yield and quality. Funct Plant Biol 21:901909.

Bonsall C. 2008. The Mesolithic of the iron gates. Mesolithic Europe 238-279.

Bonsall C, Lennon R, McSweeney K, Stewart C, Harkness D, Boroneanț V, Bartosiewicz L, Payton R, Chapman J. 1997. Mesolithic and Early Neolithic in the Iron Gates: A palaeodietary perspective. $J$ Eur archaeol 5:50-92.

Borić D. 2016. Deathways at Lepenski Vir: Patterns in Mortuary Practice. Belgrade: Serbian Archaeological Society.

Borić D. 2011. Adaptations and transformations of the Danube Gorges foragers (c. 13,000-5500 cal. BC): an overview In: Krauß R, editor. Beginnings - New Research in the Appearance of the Neolithic between Northwest Anatolia and the Carpathian Basin. Papers of the International Workshop 8th - 9th April 2009, Istanbul. Organized by Dan Ciobotaru, Barbara Horejs Und Raiko Krauß., Menschen - Kulturen - Traditionen: Studien Aus Den Forschungsclustern Des Deutschen Archäologischen Instituts; ForschungsCluster 1. Presented at the Beginnings - new research in the appearance of the Neolithic between Northwest Anatolia and the Carpathian Basin: Papers of the international workshop. Rahden/Westf.: Verlag Marie Leidorf GmbH. p. 231.

Borić D, French CAI, Stefanović S, Dimitrijević V, Cristiani E, Gurova M, Antonović D, Allué E, Filipović D. 2014. Late Mesolithic lifeways and deathways at Vlasac (Serbia). J Field Archaeol 39:4-31.

Borić D, Grupe G, Peters J, Mikić Ž. 2004. Is the Mesolithic-Neolithic subsistence dichotomy real? New stable isotope evidence from the Danube Gorges. European Journal of Archaeology 7:221-248.

Borić D, Higham T, Cristiani E, Dimitrijević V, Nehlich O, Griffiths S, Alexander C, Mihailović B, Filipović D, Allué E, Buckley M. 2018. High-Resolution AMS Dating of Architecture, Boulder Artworks and the Transition to Farming at Lepenski Vir. Sci Rep 8:14221.

Boric D, Price TD. 2013. Strontium isotopes document greater human mobility at the start of the Balkan Neolithic. Proc Natl Acad Sci U S A 110:3298-3303.

Buckley S, Usai D, Jakob T, Radini A, Hardy K. 2014. Dental calculus reveals unique insights into food items, cooking and plant processing in prehistoric central Sudan. PLoS One 9:e100808. 
Cârciumaru M. 1978. L'analyse pollinique des coprolithes de la station archéologique de Vlasac. Vlasac, A Mesolithic Settlement in the Iron Gates II: Geology, Biology, Anthropology Beograd: Srpska akademija nauka i umetnosti 31-34.

Cârciumaru M. 1973. Compte rendu de l'analyse pollinique des coprolithes d'Icoana--Portes de Fier. Actes du VIIIe Congrès International des Sciences Préhistoriques et Protohostoriques, Beograd 9-15 septembre 1971 172-173.

Clarke DL. 1978. Mesolithic Europe: the economic basis. Duckworth.

Costantini L. 1989. Plant exploitation at Grotta dell'Uzzo, Sicily: new evidence for the transition from Mesolithic to Neolithic subsistence in southern Europe In: Harris D, Hillman G, editors. Foraging and Farming: The Evolution of Plant Exploitation. Unwin Hyman Ltd.

Cristiani E, Radini A, Borić D, Robson HK, Caricola I, Carra M, Mutri G, Oxilia G, Zupancich A, Šlaus M, Vujević D. 2018. Dental calculus and isotopes provide direct evidence of fish and plant consumption in Mesolithic Mediterranean. Sci Rep 8:8147.

Cristiani E, Radini A, Edinborough M, Borić D. 2016. Dental calculus reveals Mesolithic foragers in the Balkans consumed domesticated plant foods. Proceedings of the National Academy of Sciences 113:10298-10303.

Cristiani E, Zupancich A. 2020. Sandstone Ground Stone Technology: a Multi-level Use Wear and Residue Approach to Investigate the Function of Pounding and Grinding Tools. Journal of Archaeological Method and Theory. doi:10.1007/s10816-020-09488-1

Cummings LS, Yost C, Sołtysiak A. 2018. Plant microfossils in human dental calculus from Nemrik 9, a Pre-Pottery Neolithic site in Northern Iraq. Archaeol Anthropol Sci 10:883891.

de Beaune SA. 2004. The Invention of Technology: Prehistory and Cognition. Curr Anthropol 45:139-162.

Dietrich L, Meister J, Dietrich O, Notroff J, Kiep J, Heeb J, Beuger A, Schütt B. 2019. Cereal processing at Early Neolithic Göbekli Tepe, southeastern Turkey. PLoS One 14: 0215214 .

Divišová M, Śída P. 2015. Plant use in the Mesolithic period. Archaeobotanical data from the Czech Republic in a European context - A review. Interdisciplinaria Archaeologica: Natural Sciences in Archaeology 6:95-106.

Dubreuil L, Nadel D. 2015. The development of plant food processing in the Levant: insights from use-wear analysis of Early Epipalaeolithic ground stone tools. Philos Trans $R$ Soc Lond B Biol Sci 370. doi:10.1098/rstb.2014.0357

Dubreuil L, Savage D, Delgado-Raack S, Plisson H, Stephenson B, de la Torre I. 2015. Current Analytical Frameworks for Studies of Use-Wear on Ground Stone Tools In: Marreiros JM, Gibaja Bao JF, Ferreira Bicho N, editors. Use-Wear and Residue Analysis in Archaeology. Cham: Springer International Publishing. pp. 105-158.

Edwards KJ. 1989. The cereal pollen record and early agriculture. BAR International Series $113-135$.

Filipović D, Allué EA, Borić D. 2010. Integrated carpological and antracological analysis of plant record from the Mesolithic site of Vlasac, Serbia. Journal of the Serbian Archaeological Society 26:145-161.

Fuller DQ, Willcox G, Allaby RG. 2011. Cultivation and domestication had multiple origins: arguments against the core area hypothesis for the origins of agriculture in the Near East. World Archaeol 43:628-652.

Geera BP, Nelson JE, Souza E, Huber KC. 2006. Composition and properties of A- and B-type starch granules of wild-type, partial waxy, and waxy soft wheat. Cereal Chem 83:551557. 
Halstead P. 1996. The development of agriculture and pastoralism in Greece: When, how, who and what. The origins and spread of agriculture and pastoralism in Eurasia 296-309.

Hamon C, Cagnato C, Emery-Barbier A, Salavert A. 2021. Food practices of the first farmers of Europe: Combined use-wear and microbotanical studies of Early Neolithic grinding tools from the Paris Basin. J Archaeol Sci Rep 36:102764.

Hamon C, Plisson H. 2009. Functional analysis of grinding stones: the blind-test contribution In: Skakun N. LL, editor. Prehistoric Technology 40 Years Later: Functional Studies and the Russian Legacy. BAR International Series. pp. 29-38.

Hansen JM. 1991. The Palaeoethnobotany of Franchthi Cave. Indiana University Press.

Haslam M. 2004. The decomposition of starch grains in soils: implications for archaeological residue analyses. J Archaeol Sci 31:1715-1734.

Hastorf CA, Foxhall L. 2017. The social and political aspects of food surplus. World Archaeol 49:26-39.

Henry AG, Brooks AS, Piperno DR. 2011. Microfossils in calculus demonstrate consumption of plants and cooked foods in Neanderthal diets (Shanidar III, Iraq; Spy I and II, Belgium). Proc Natl Acad Sci U S A 108:486-491.

Henry AG, Piperno DR. 2008. Using plant microfossils from dental calculus to recover human diet: a case study from Tell al-Raqā'i, Syria. J Archaeol Sci 35:1943-1950.

Holden TG, Hather JG, Watson JPN. 1995. Mesolithic plant exploitation at the Roc del Migdia, Catalonia. J Archaeol Sci 22:769-778.

Howard T, Rejab NA, Griffiths S, Leigh F, Leverington-Waite M, Simmonds J, Uauy C, Trafford K. 2011. Identification of a major QTL controlling the content of B-type starch granules in Aegilops. J Exp Bot 62:2217-2228.

Jovanović J, Power RC, de Becdelièvre C, Goude G, Stefanović S. 2021. Microbotanical evidence for the spread of cereal use during the Mesolithic-Neolithic transition in the Southeastern Europe (Danube Gorges): Data from dental calculus analysis. J Archaeol Sci 125: 105288 .

Jovanović J, Blagojević T, Marković J, Novak M, Bedić Ž, Naumov G, Stojanova Kanzurova E, Los Dž, Hutinec M, Fidanoski Lj, Skelac G, Šlaus M, Stefanović S. 2021. New radiocarbon dates, stable isotope, and anthropological analysis of prehistoric human bones from the Balkans and southwestern Carpathian Basin. Documenta Praehistorica 48:2-29.

Kotsakis K. 2003. From the Neolithic side: the Mesolithic/Neolithic interface in Greece. British School at Athens Studies 10:217-221.

Kotzamani G, Livarda A. 2014. Plant resource availability and management in Palaeolithic and Mesolithic Greece In: Laffineur R, Touchais G, Rougemont F, editors. Physis: L'environnement Naturel et La Relation Homme-Milieu Dans Le Monde Égéen Protohistorique, Aegaeum (Annales d'archéologie Égéenne de l'Université de Liège et UT-PASP). Peeters Publishers.

Kubiak-Martens L. 1999. The plant food component of the diet at the Late Mesolithic (Ertebølle) settlement at Tybrind Vig, Denmark. Veg Hist Archaeobot 8:117-127.

Langejans GHJ. 2010. Remains of the day-preservation of organic micro-residues on stone tools. J Archaeol Sci 37:971-985.

Lazaridis I, et al. 2021. The genetic history of the Southern Arc: A bridge between West Asia and Europe.

Lee RB, DeVore I. 2017. Man the Hunter. Routledge.

Lippi MM, Foggi B, Aranguren B, Ronchitelli A, Revedin A. 2015. Multistep food plant processing at Grotta Paglicci (Southern Italy) around 32,600 cal BP. Proceedings of the national Academy of Sciences 112:12075-12080. 
Liu L, Field J, Fullagar R, Bestel S, Chen X, Ma X. 2010. What did grinding stones grind? New light on Early Neolithic subsistence economy in the Middle Yellow River Valley, China. Antiquity 84:816-833.

Livarda A. 2011. Spicing up life in northwestern Europe: exotic food plant imports in the Roman and medieval world. Veg Hist Archaeobot 20:143-164.

Lombardo U, Iriarte J, Hilbert L, Ruiz-Pérez J, Capriles JM, Veit H. 2020. Early Holocene crop cultivation and landscape modification in Amazonia. Nature 581:190-193.

Lowie RH. 1922. Material Culture of the Crow Indians. Lakota Books.

Lucarini G, Radini A, Barton H, Barker G. 2016. The exploitation of wild plants in Neolithic North Africa. Use-wear and residue analysis on non-knapped stone tools from the Haua Fteah cave, Cyrenaica, Libya. Quat Int 410:77-92.

Madella M, Lancelotti C, García-Granero JJ. 2016. Millet microremains-an alternative approach to understand cultivation and use of critical crops in Prehistory. Archaeol Anthropol Sci 8:17-28.

Marinova E, Filipovic D, Obradović D, Allué E. 2013. Wild plant resources and land use in the Mesolithic and early Neolithic south-east Europe: Archaeobotanical evidence from the Danube catchment of Bulgaria and Serbia. Offa 69:467-478.

Mason S, Boroneanţ V, Bonsall C. 1996. Plant remains from Schela Cladovei, Romania. Mesolithic Miscellany 17:11-14.

Mason SLR. 1995. Acornutopia? Determining the role of acorns in past human subsistence. Food in antiquity 12-24.

Mathieson I, Alpaslan-Roodenberg S, Posth C, Szécsényi-Nagy A, Rohland N, Mallick S, Olalde I, Broomandkhoshbacht N, Candilio F, Cheronet O, Fernandes D, Ferry M, Gamarra B, Fortes GG, Haak W, Harney E, Jones E, Keating D, Krause-Kyora B, Kucukkalipci I, Michel M, Mittnik A, Nägele K, Novak M, Oppenheimer J, Patterson N, Pfrengle S, Sirak K, Stewardson K, Vai S, Alexandrov S, Alt KW, Andreescu R, Antonović D, Ash A, Atanassova N, Bacvarov K, Gusztáv MB, Bocherens H, Bolus M, Boroneanţ A, Boyadzhiev Y, Budnik A, Burmaz J, Chohadzhiev S, Conard NJ, Cottiaux R, Čuka M, Cupillard C, Drucker DG, Elenski N, Francken M, Galabova B, Ganetsovski G, Gély B, Hajdu T, Handzhyiska V, Harvati K, Higham T, Iliev S, Janković I, Karavanić I, Kennett DJ, Komšo D, Kozak A, Labuda D, Lari M, Lazar C, Leppek M, Leshtakov K, Vetro DL, Los D, Lozanov I, Malina M, Martini F, McSweeney K, Meller H, Menđušić M, Mirea P, Moiseyev V, Petrova V, Price TD, Simalcsik A, Sineo L, Šlaus M, Slavchev V, Stanev P, Starović A, Szeniczey T, Talamo S, Teschler-Nicola M, Thevenet C, Valchev I, Valentin F, Vasilyev S, Veljanovska F, Venelinova S, Veselovskaya E, Viola B, Virag C, Zaninović J, Zäuner S, Stockhammer PW, Catalano G, Krauß R, Caramelli D, Zarina G, Gaydarska B, Lillie M, Nikitin AG, Potekhina I, Papathanasiou A, Borić D, Bonsall C, Krause J, Pinhasi R, Reich D. 2018. The genomic history of southeastern Europe. Nature 555:197-203.

Nadel D, Piperno DR, Holst I, Snir A, Weiss E. 2012. New evidence for the processing of wild cereal grains at Ohalo II, a 23 000-year-old campsite on the shore of the Sea of Galilee, Israel. Antiquity 86:990-1003.

Nava A, Fiorin E, Zupancich A, Carra M, Ottoni C, Di Carlo G, Vozza I, Brugnoletti O, Alhaique F, Cremonesi RG, Coppa A, Bondioli L, Borić D, Cristiani E. 2021. Multipronged dental analyses reveal dietary differences in last foragers and first farmers at Grotta Continenza, central Italy (15,500-7000 BP). Sci Rep 11:4261.

Norström E, Gustavsson R, Molin F, Gummesson S. 2019. Micro-fossil analysis of Mesolithic human dental calculus, Motala, Sweden - Indications of health status and paleo-diet. Journal of Archaeological Science: Reports 26:101866. 
Ottoni C, Borić D, Cheronet O, Sparacello V, Dori I, Coppa A, Antonović D, Vujević D, Douglas Price T, Pinhasi R, Cristiani E. 2021. Tracking the transition to agriculture in Southern Europe through ancient DNA analysis of dental calculus. Proc Natl Acad Sci U $S$ A 118. doi:10.1073/pnas. 2102116118

Pardoe C, Fullagar R, Hayes E. 2019. Quandong stones: A specialised Australian nut-cracking tool. PLoS One 14:e0222680.

Piperno DR, Weiss E, Holst I, Nadel D. 2004. Processing of wild cereal grains in the Upper Palaeolithic revealed by starch grain analysis. Nature 430:670-673.

Portillo M, Albert RM. 2014. Microfossil evidence for grinding activities. Revista d'arqueologia de Ponent.

Pryor AJE, Steele M, Jones MK, Svoboda J, Beresford-Jones DG. 2013. Plant foods in the Upper Palaeolithic at Dolní Věstonice? Parenchyma redux. Antiquity 87:971-984.

Radini A, Buckley S, Rosas A, Estalrrich A, de la Rasilla M, Hardy K. 2016. Neanderthals, trees and dental calculus: new evidence from El Sidrón. Antiquity 90:290-301.

Radini A, Nikita E, Buckley S, Copeland L, Hardy K. 2017. Beyond food: The multiple pathways for inclusion of materials into ancient dental calculus. Am J Phys Anthropol 162:71-83.

Radini A, Tromp M, Beach A, Tong E, Speller C, McCormick M, Dudgeon JV, Collins MJ, Rühli F, Kröger R, Warinner C. 2019. Medieval women's early involvement in manuscript production suggested by lapis lazuli identification in dental calculus. Sci Adv 5:eaau7126.

Radovanović I. 1996. The Iron Gates Mesolithic. International Monographs in Prehistory Ann Arbor (Michigan).

Reimer PJ, Austin WEN, Bard E, Bayliss A, Blackwell PG, Bronk Ramsey C, Butzin M, Cheng H, Edwards RL, Friedrich M, Grootes PM, Guilderson TP, Hajdas I, Heaton TJ, Hogg AG, Hughen KA, Kromer B, Manning SW, Muscheler R, Palmer JG, Pearson C, Plicht J van der, Reimer RW, Richards DA, Scott EM, Southon JR, Turney CSM, Wacker L, Adolphi F, Büntgen U, Capano M, Fahrni SM, Fogtmann-Schulz A, Friedrich R, Köhler P, Kudsk S, Miyake F, Olsen J, Reinig F, Sakamoto M, Sookdeo A, Talamo S. 2020. The IntCal20 Northern hemisphere radiocarbon age calibration curve (0-55 cal kBP). Radiocarbon 62:725-757.

Rowley-Conwy P, Layton R. 2011. Foraging and farming as niche construction: Stable and unstable adaptations. Philos Trans R Soc Lond B Biol Sci 366:849-862.

Sabin S, Fellow Yates J. 2020. Dental Calculus Field-Sampling Protocol (Sabin version) v2 (protocols.io.bqecmtaw). protocols.io. doi:10.17504/protocols.io.bqecmtaw

Scott AC, Damblon F. 2010. Charcoal: Taphonomy and significance in geology, botany and archaeology. Palaeogeogr Palaeoclimatol Palaeoecol 291:1-10.

Siegfried EV. 1994. Ethnobotany of the northern Cree of Wabasca/Desmarais. University of Calgary.

Smith BD. 2011. A cultural niche construction theory of initial domestication. Biol Theory 6:260-271.

Soto M, Inwood J, Clarke S, Crowther A, Covelli D, Favreau J, Itambu M, Larter S, Lee P, Lozano M, Maley J, Mwambwiga A, Patalano R, Sammynaiken R, Vergès JM, Zhu J, Mercader J. 2019. Structural characterization and decontamination of dental calculus for ancient starch research. Archaeol Anthropol Sci. doi:10.1007/s12520-019-00830-7

Srejović D. 1988. The Neolithic of Serbia: Archaeological research 1948-1988. University of Belgrade, Fac. of Philosophy, Centre for Archaeological Research.

Srejović D. 1972. New Discoveries at Lepenski Vir: Europe's First Monumental Sculpture. Thames and Hudson. 
Srejović D, Letica Z. 1978. Vlasac: A Mesolithic Settlement in the Iron Gates. Serbian Academy of Sciences and Arts.

Stoddard FL. 1999. Survey of starch particle-size distribution in wheat and related species. Cereal Chem 76:145-149.

Stoddard FL, Sarker R. 2000. Characterization of Starch in Aegilops Species. Cereal Chemistry Journal 77:445-447.

Van Andel TH, Sutton SB, Vitaliano CJ. 1987. Landscape and People of the Franchthi Region. Indiana University Press.

Vaquer J, Geddes D, Barbaza M, Erroux J. 1986. Mesolithic plant exploitation at the Balma Abeurador (France). Oxford Journal of Archaeology 5:1-18.

Weber SA, Fuller DQ. 2008. Millets and their role in early agriculture. Pragdhara 18:e90.

Wright KI. 1994. Ground-stone tools and hunter-gatherer subsistence in southwest Asia: Implications for the transition to farming. Am Antiq 59:238-263.

y'Edynak G, Fleisch S. 1983. Microevolution and biological adaptability in the transition from food-collecting to food-producing in the Iron Gates of Yugoslavia. J Hum Evol 12:279296.

Yang X, Perry L. 2013. Identification of ancient starch grains from the tribe Triticeae in the North China Plain. J Archaeol Sci 40:3170-3177.

Zarrillo S, Kooyman B. 2006. Evidence for Berry and Maize Processing on the Canadian Plains from Starch Grain Analysis. Am Antiq 71:473-499.

Zvelebil M. 1994. Plant use in the Mesolithic and its role in the transition to farming. Proceedings of the Prehistoric Society 60:35-74.

\section{Figures and Tables}

Figure 1. Sites in the central Balkans investigated in the article, which provided dental calculus and ground stone tools. $\mathrm{EM}=$ Early Mesolithic; $\mathrm{LM}=$ Late Mesolithic; $\mathrm{M} / \mathrm{N}=$ Mesolithic/Neolithic; $\mathrm{N}=$ Neolithic; BA = Bronze Age; MA = Medieval.

Figure 2. Studied teeth photographed under the microscope before dental calculus sampling.

Figure 3. Late Mesolithic GSTs from the site of Vlasac featuring use-wear traces and residues related to plant food processing.

Figure 4. Starch granules from Mesolithic and Neolithic dental calculus. Early Mesolithic: (a) Type Ib (PAD11); (b) Type Ib (PAD9); (c) Type Ib (PAD11); (d) Type V (PAD12); (e) Type III (PAD11); (f) Type Ib (PAD15); Late Mesolithic: (g) Type II (VL82c); (h) Type IV (VL31); (i) Type VI (VL70); (j, k) Multicellular structures of long cells embedded in dental calculus (HV25/26, VL70); (l) Type Ia (HV11); Mesolithic-Neolithic: (m) Type Ia (HV16). Neolithic: (n) Type III (LV32a); (o-v) Damaged Type I granules (A-Type granules) (VEL-2D); (w) Type I (A-Type granule) (VEL-2D); (x) Single dendritic cell (Gârleşti); (y) Type I (A-Type granule) (VEL-2D) (VEL-2A).

Figure 5. Other dietary and non-dietary debris found in Mesolithic dental calculus from the Danube Gorges. Early Mesolithic: (a) Type V (PAD11); (b,c) Type III (PAD12); (d) Type I (AType granule) (VEL-2D) (PAD12); (e) Type I (A-Type granule) (PAD12); (f) Smoke particle 
(LV50); (g, h) Plant fiber embedded in calculus (PAD16); (i) Type Ib (PAD9); (j) Feather barbule embedded in calculus (PAD9); Late Mesolithic: (k) Type II (PAD2); (l) Polylobate phytolith (US64 x.11); (m) Phytoliths (VL79); (n-p) Type VI (VL70,VL83); (q) Feather barbules embedded in calculus (HV25/26); (r) Feather barbule embedded in calculus (VL80a); (s) Echinate pollen grain in calculus (VL83); (t) Plant tissue (LV79a); (u) Type II (VL43); (v) Type Ia (HV11); Mesolithic/Neolithic: (w) Type I (HV16); (x) Wood particle (PAD4); (y) Phytoliths (LV28); (z) Feather barbule (PAD4).

Figure 6. Starch granule morphological variability within the species of the genus Aegilops and domestic species of the Triticeae tribe. a) Aegilops cylindrica; b) A. neglecta; c) A. speltoides tauschii; d) A. caudata; e) A. triuncialis; f) A. comosa; g) A. uniaristata; h) A. ventricosa; i) A. geniculata; j) A. crassa; k) A. peregrina; l) Elymus caninus; m) Bromus tectorum; n) Agropyron pungens; o) A. farctus; p) Dasypyron villosum; q) Triticum monococcum; r) Hordeum vulgare; $\mathbf{s})$ T. dicoccum; $\mathbf{t}$ ) T. aestivum.

Figure 7. Experimental reference for starch granules identified in the dental calculus and GSTs. a) Aegilops triuncialis; b) A. crassa; $\mathbf{c}, \mathbf{d})$ Avena strigosa; $\mathbf{e , f ) ~ S e t a r i a ~ i t a l i c a ; ~ g ) ~ V i c i a ~ c r a c c a ; ~} \mathbf{h}$ ) $V$. sylvatica; i) Quercus pubescens; j) $Q$. robur; k) $Q$. colurna; l) Cornus mas.

Figure 8. Experimental macro residues and micro polish associated with grass grains processing compared to macro residue and micro polish identified on archaeological GSTs from the site of Vlasac; a-e) yellowish organic film covering the crystal grains on experimental GSTs used to process oat (a), downy brome (b), wild grass grains, (c) and millet (d); smooth domed and flat micro polish developing over the high and low micro topographies associated with oat (Avena barbata) grinding; $\mathbf{f}$ ) smooth flat and domed micro polish developing over the surface high and low micro topographies and characterized by narrow micro striations associated with grinding downy brome (Bromus tectorum L.); g) smooth flat micro polish developed over the high and low micro topographies characterized by sporadic narrow striations associated with grinding wild grass grains (Aegilops ventricosa Tausch); h) smooth domed polish developed over the high and low micro topographies associated with the grinding of foxtail millet (Setaria italica (L.) P. Beauvois); i-l) spots of organic film, yellowish in color covering the crystal grains across the surface of archaeological GSTs; m,p) smooth domed micro polish identified on archaeological GSTs developing over the high and low surface micro topographies and associated with micro striations (m,n,p). q-w Starch granules identified on archaeological GSTs. (q) Type I (GST no. INV80); (r) Type I (GST no. INV146); (S) Type III (GST no. INV 28); (t) Type VI (GST no. INV.67); (u) Type VI (GST no. INV 10); (v) Type VI (GST no. INV146); (w) Type I (GST no. INV.71).

Figure 9. Starch granule length in modern wild and domestic cereal species. a) Distribution of starch granule length in wild species; b) distribution of domesticated species; c) Violin plot of comparing the length of starch granules in wild and domesticated species; d) Interquartile Range (IQR) ranges of wild and domestic species. IQR corresponds to the difference in the medians of the lower and upper half of the data. 
1239 Figure 10. Controls for contamination. (a-w) Evidence of pollutants retrieved from clean working surfaces and dust traps located in different areas of the DANTE Laboratory at Sapienza University of Rome; (x-Ll) Dust recorded in storage boxes where groundstone tools were stored at the Faculty of Philosophy, University of Belgrade.

Table 1. Analyzed individuals and results.

Table 2. Details of the micro-debris (starch granules and other micro-remains) found in the archaeological dental calculus samples ( $\mathrm{PO}=\mathrm{Pollen} ; \mathrm{W}=\mathrm{Wood}$; $\mathrm{Ch}=\mathrm{Charcoal}$; $\mathrm{Gr}=\mathrm{Grit}$; $\mathrm{P}=$ Phytoliths; FE=Feathers; FI=Fibers; FU=Fungi; $=$ =Smoke $)(\mathrm{n}=51)$.

Table 3. Late Mesolithic GSTs from the site of Vlasac.

Table 4. Summary statistics of the length of modern starch granules of Aegilops, Hordeum, and Triticum species.

Table 5. Significance analysis performed on the length distribution of modern starches from Aegilops, Hordeum, and Triticum species ( $p$-value: not significant/n.s. $>0.05 ; *<0.05 ; * *<0.01$; $* * *<0.001)$. 


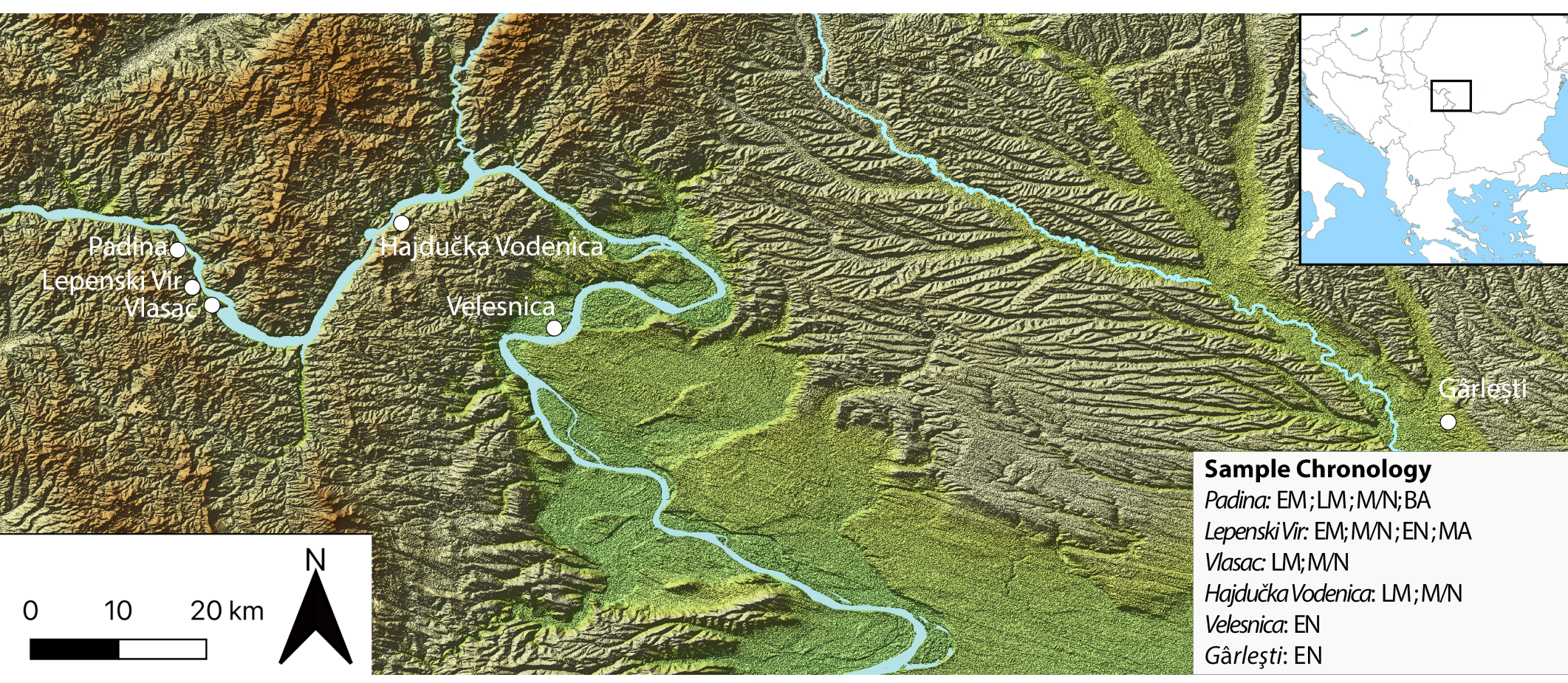


Figure 2

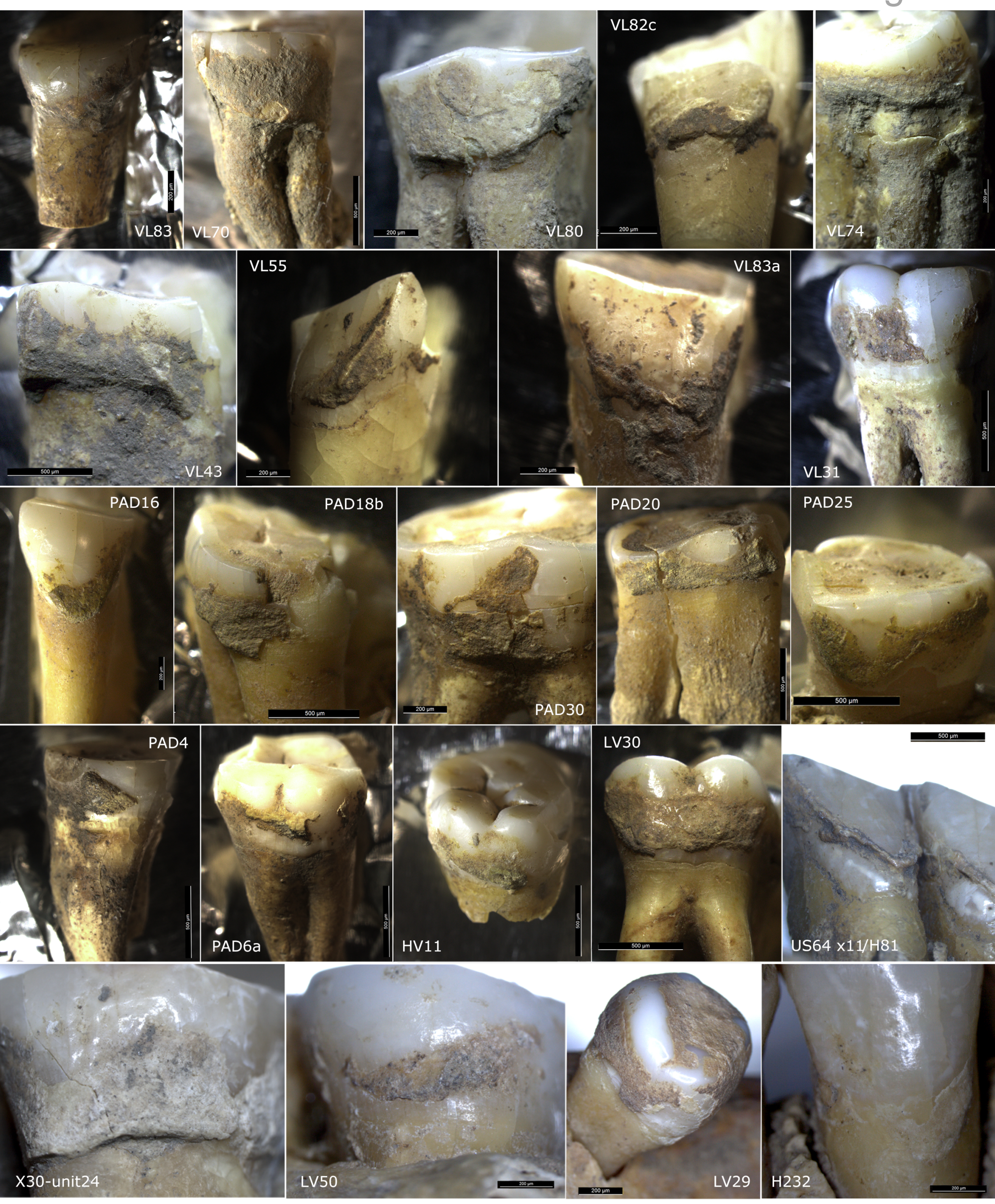


Figure 4

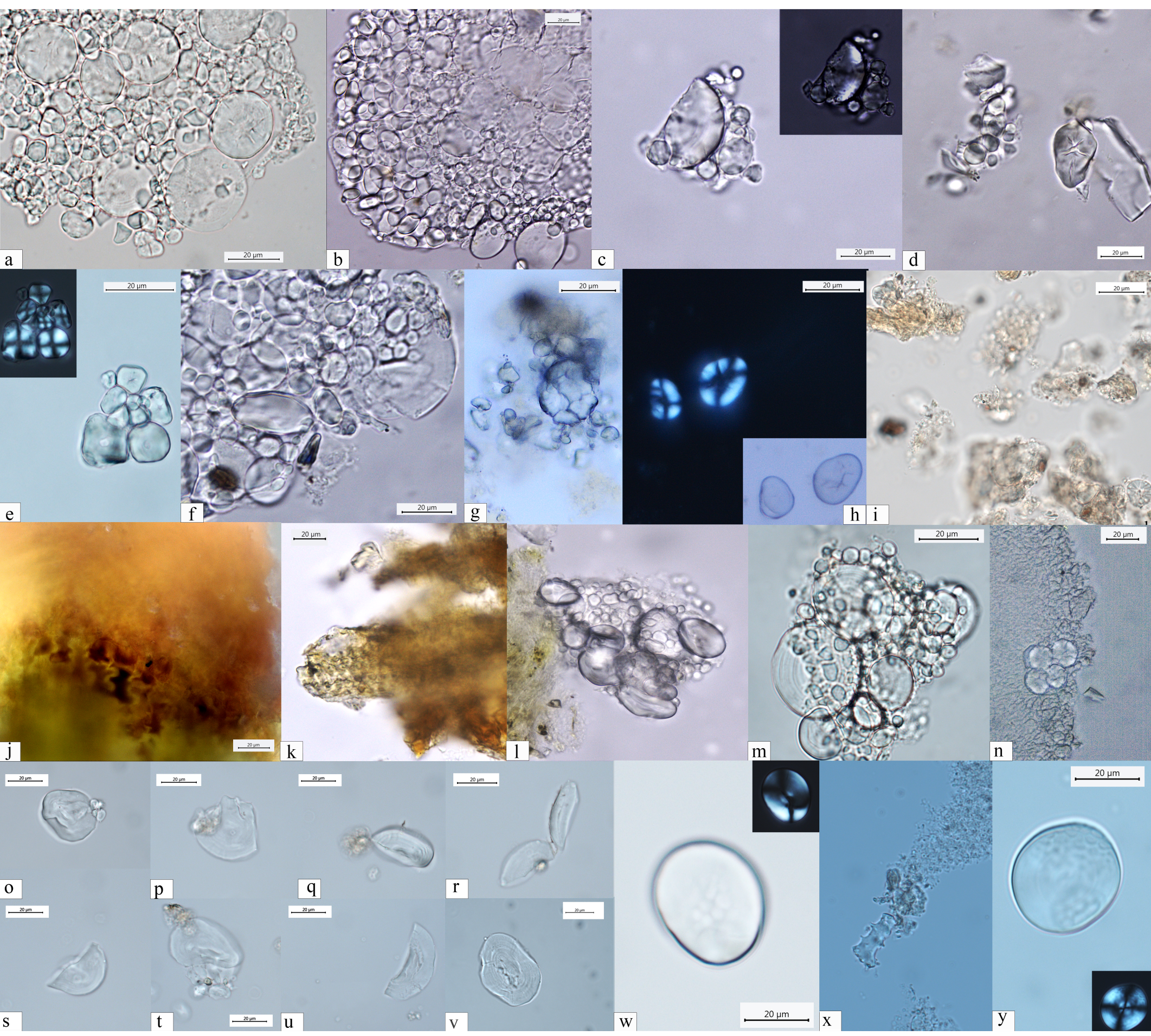


Figure 5

a d के की

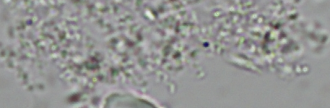

(2)

2.
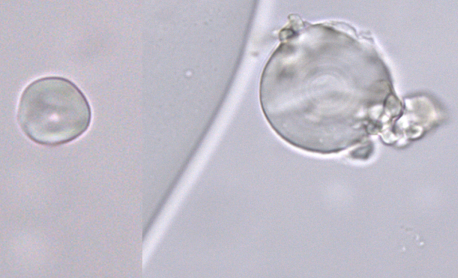

0

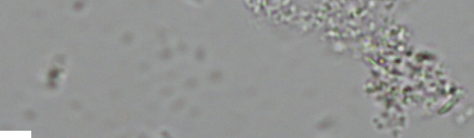

a

b

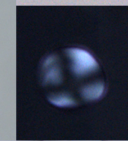

c
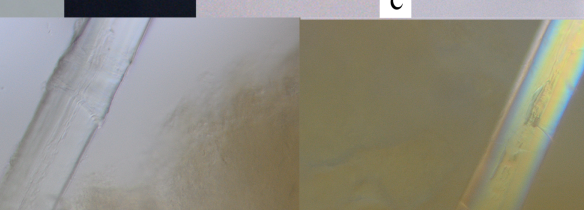

d

की 30 की

He $\times 2 x$

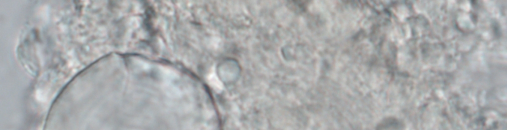

$4(2+3)$

(a) 6
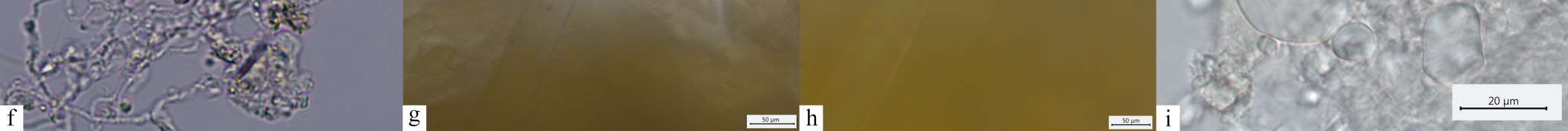

s.m. $\mathrm{k}$
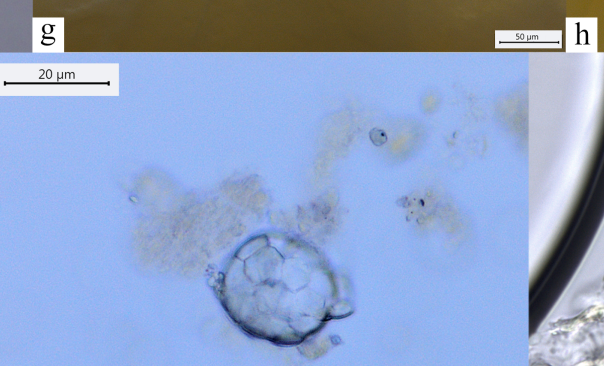

i

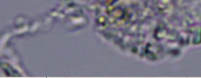

$\theta$

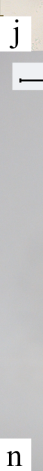

\begin{tabular}{l}
$\mathrm{j}$ \\
\hline $\mathrm{n}$
\end{tabular}
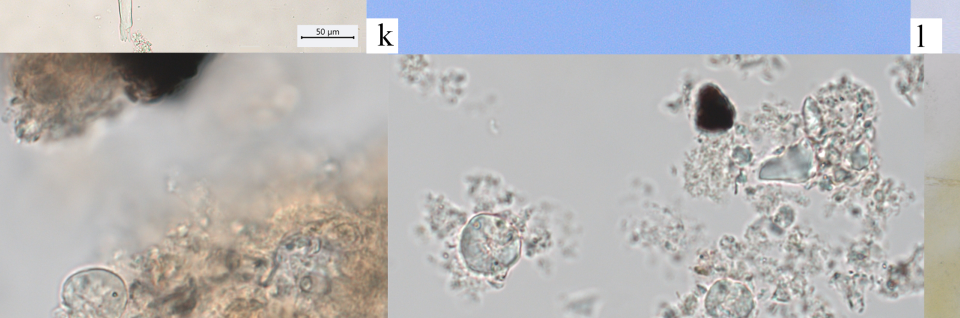

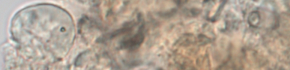

(3)
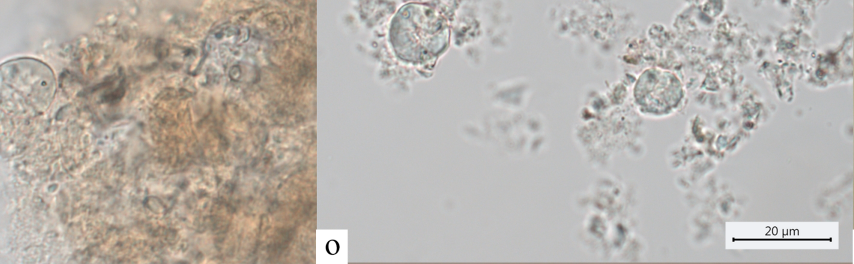

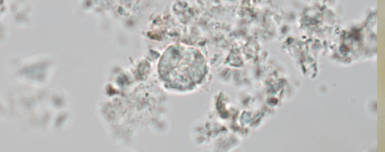
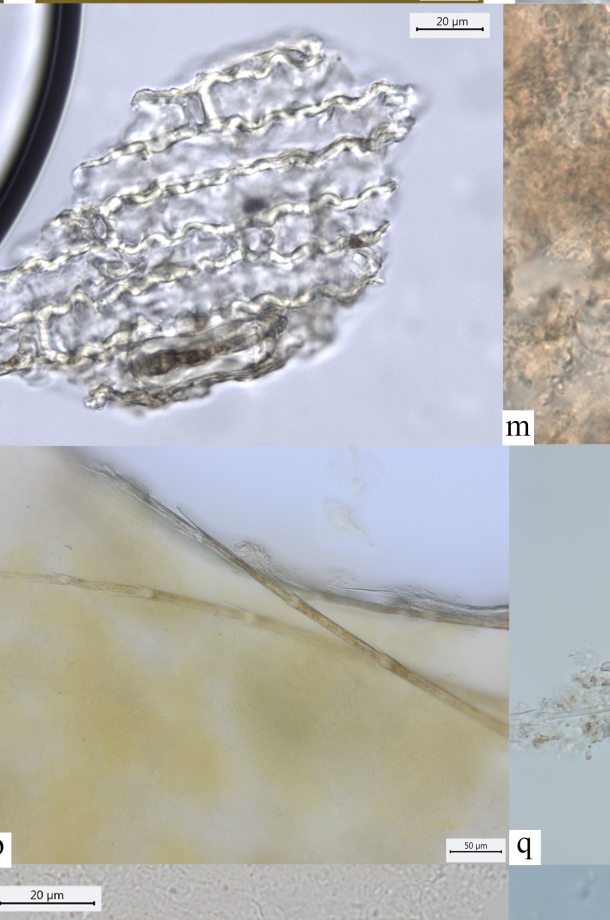
Figure 6

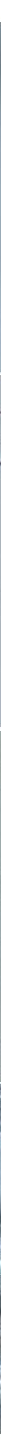


Figure 7

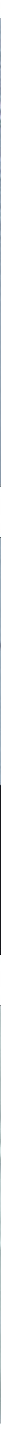




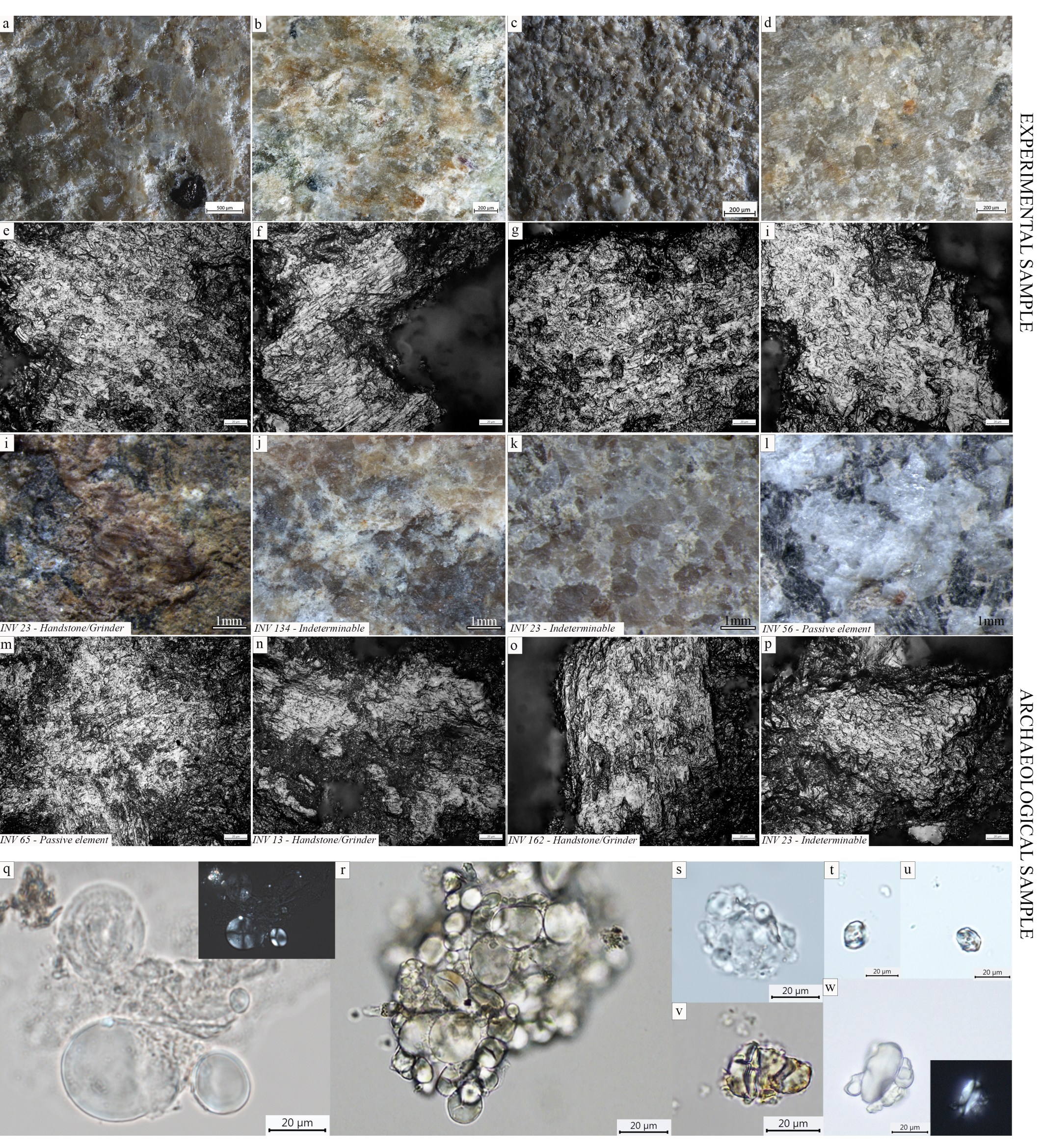


a) Distribution of starch granule length by species
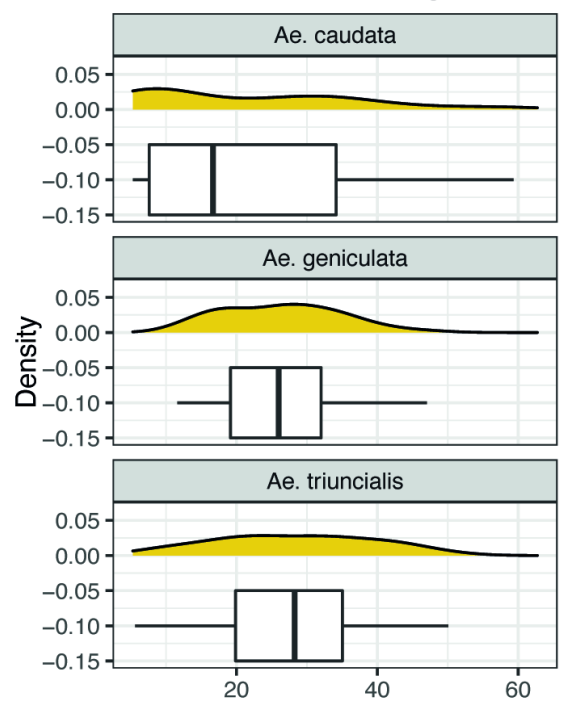

b) Distribution of starch granules length by species
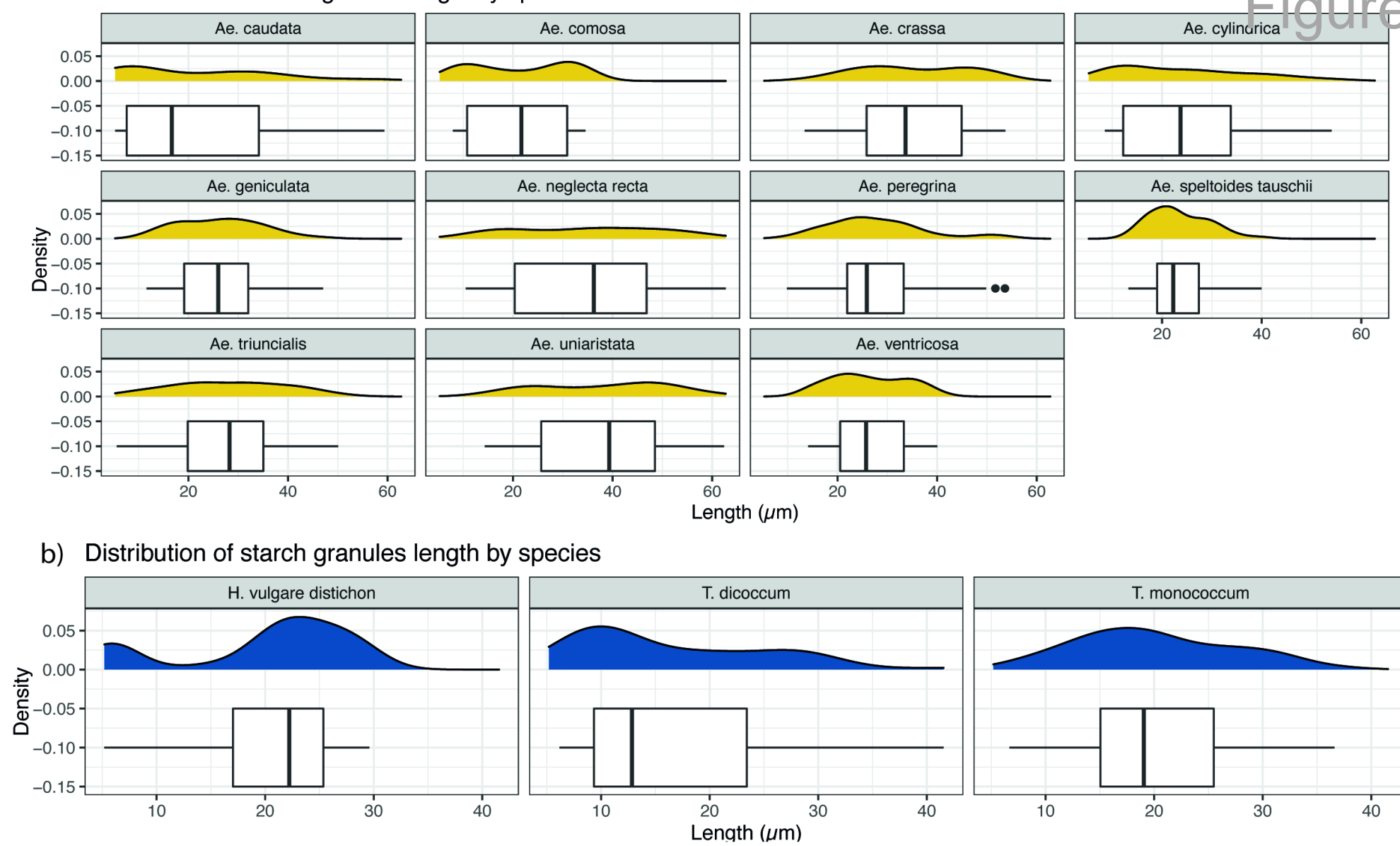

Length $(\mu \mathrm{m})$

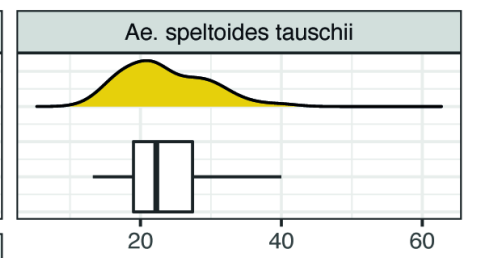

c) Length of starch granules

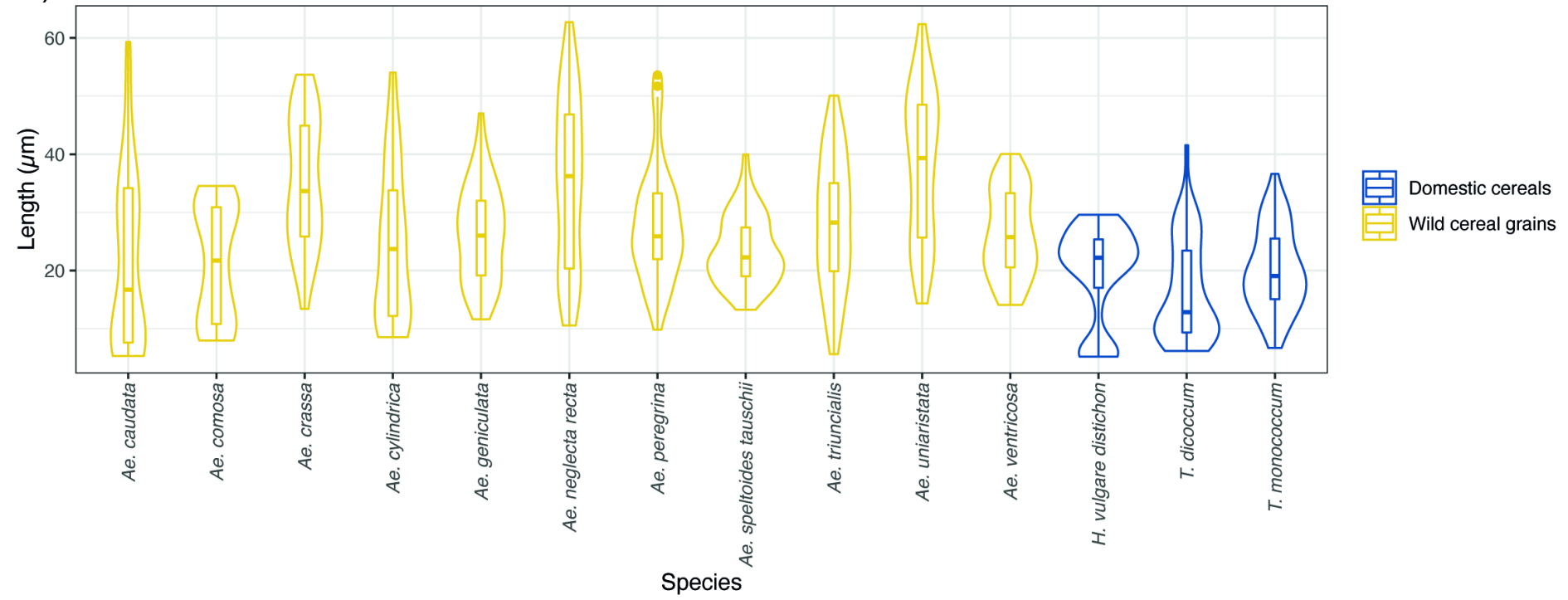

d) Variation in length of starch granules

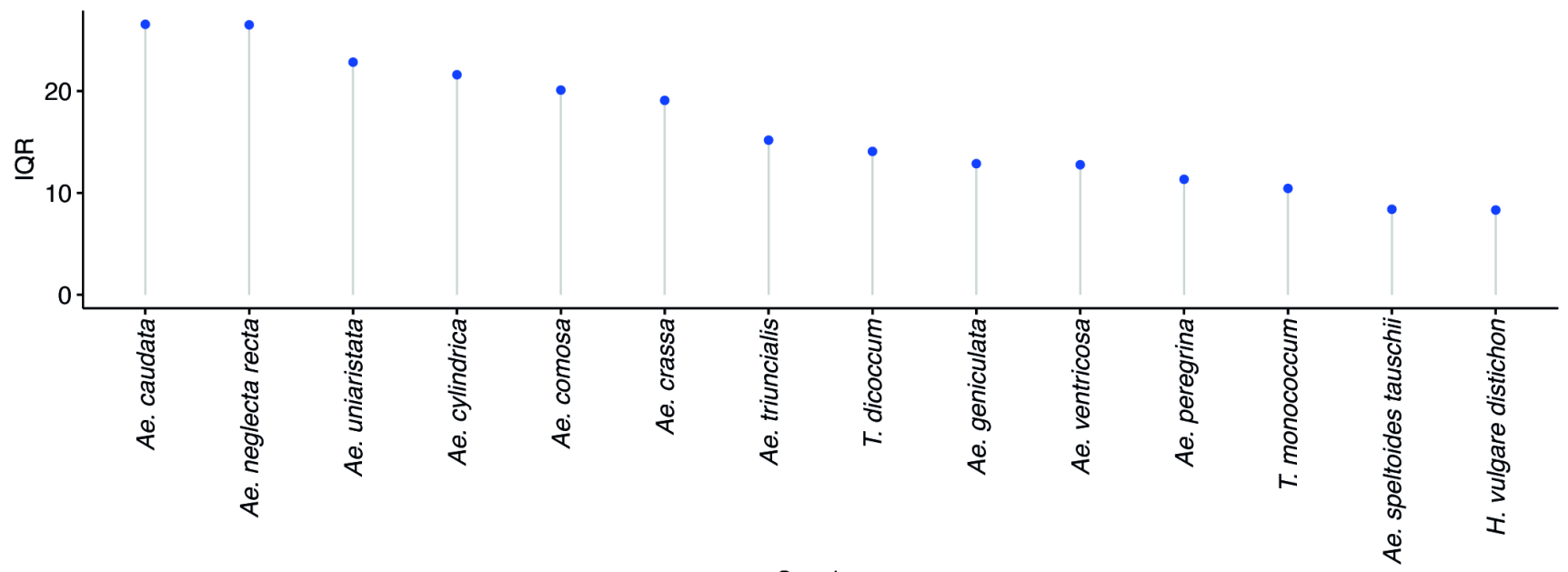


Figure 10

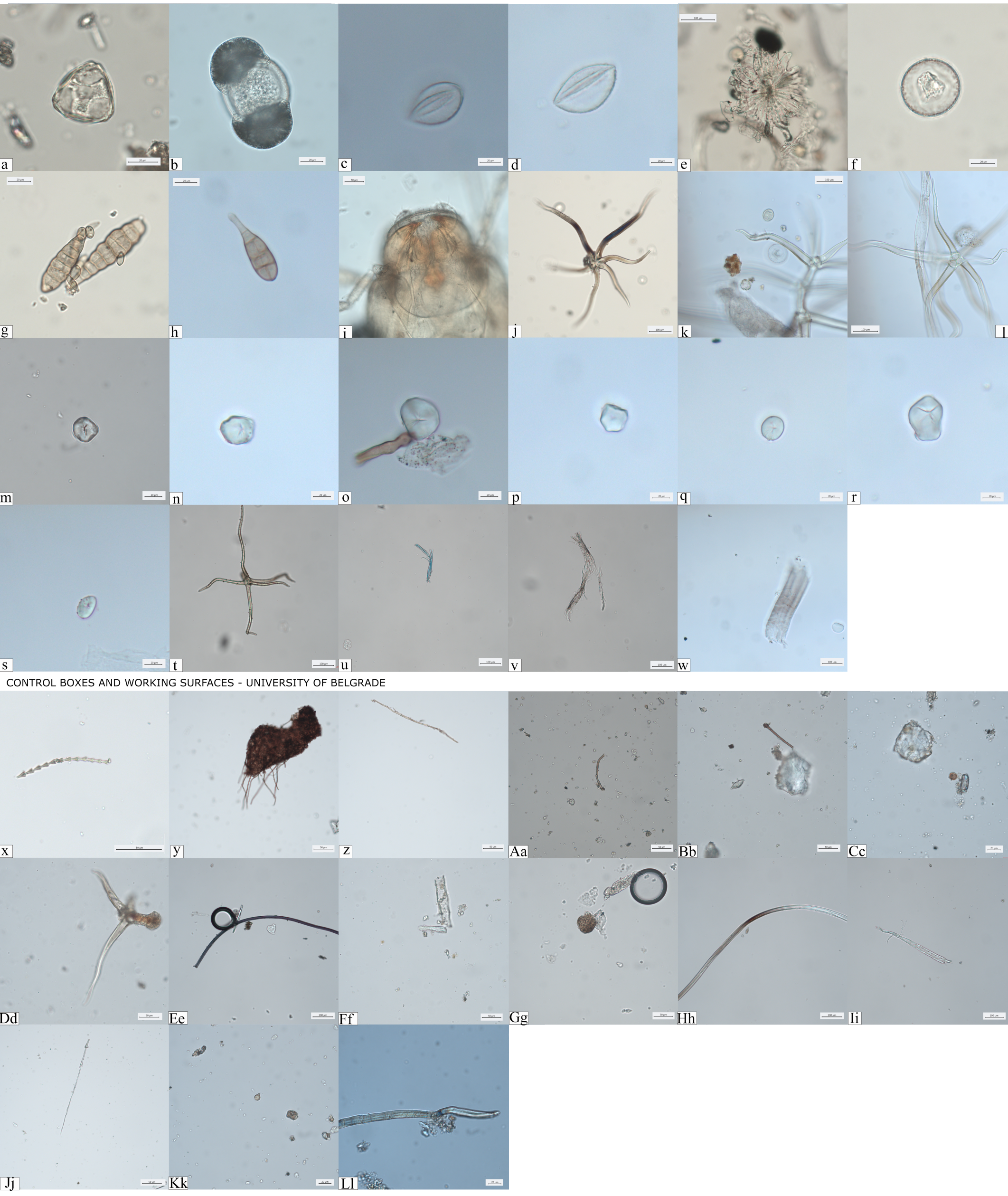

